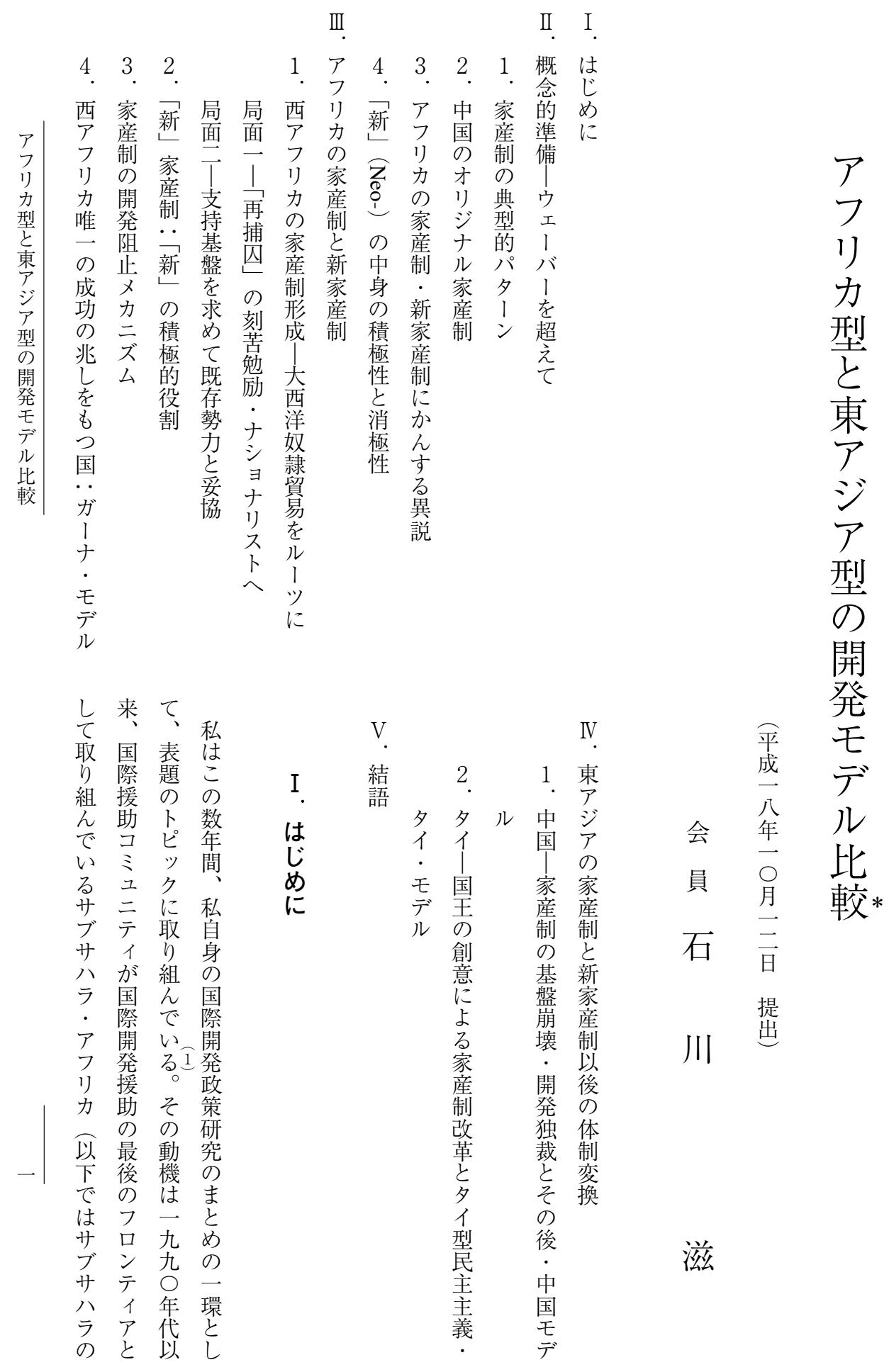


概 性 扱が者がれ者、使構で式ア段をてう献限 念の

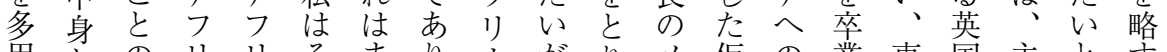
用と の リ リ ぞ カ

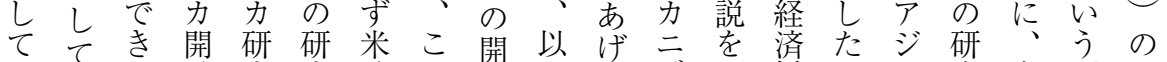
いマる 発究究欧の発下る ズい援か、究今願問

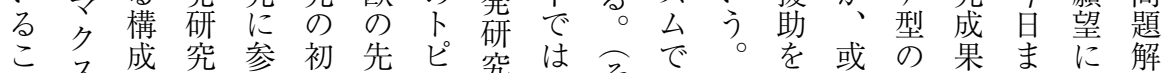

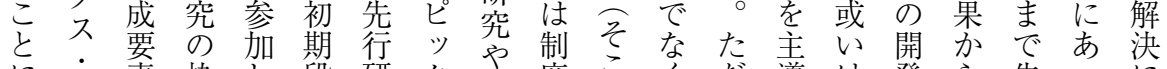
にウ素枠し 段研ク開度こくた導は発ら先つに

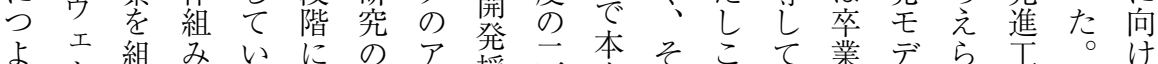

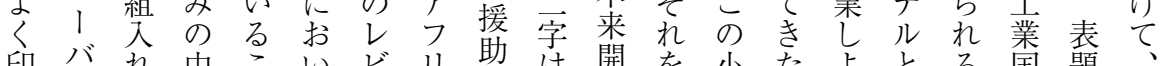
象 げの い泉に に ら家 こ 前驚

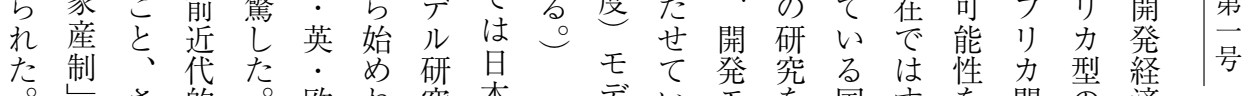

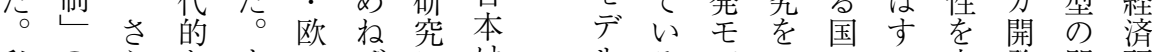

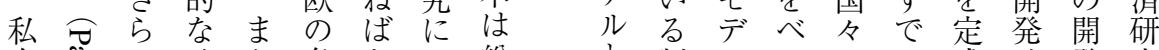
自总に政た多なつ総と制ル!のに式政発究

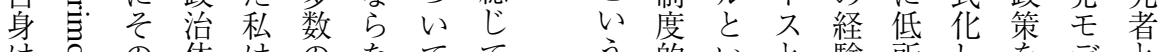
は怘の体はのなう的いと験所しをデと

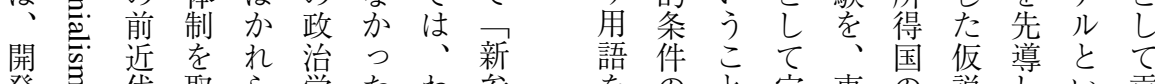
発导代取ら学たわ参势のと定東の説しい貢

家 西 節の念本 互の私直的お的家研バ一経

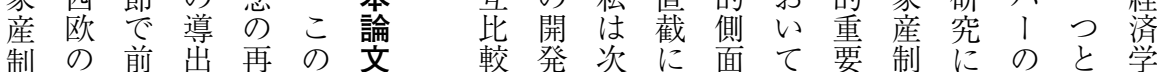
の国近に吟報の 呼民代努味告 プ 相デに琞、こ学そ立産て究 称国的力を互儿京劣家れ担れた制口に と家政し土はシ学を去は産まうがせ 体慣さ さ治、台こ習作エる制で要克て 制習い れ 总体相との れ 芯制 互意 い怘 の 較な゙を る 怘 類・較が索 新々型相、百集 新之家何亡 学地両化 産らて習域る 制かのをにた の家企そめ、 各形産でれ 接やいれ工 寻触、。特 । 异しア 以有バ 後挌恋開の 変力は発家 $\begin{array}{lllll} & \text { 容 } & \text { 諸 } & \text { モ } & \text { 産 } \\ \text { か } & \text { 第 } & \text { デ } & \text { 制 } \\ \text { 而 } & \text { 概 }\end{array}$ が製、尘概経因服き孝経し きる|ス学は狂学りり・開 るこのに説の枟な石入慣発 ででのの要念つめめる 政デ はア概後因念たて二こ治ル なフ念しとけ。開九と治の

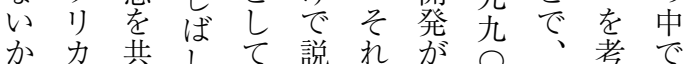

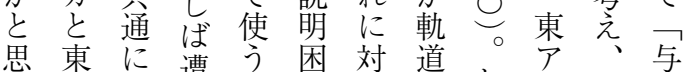

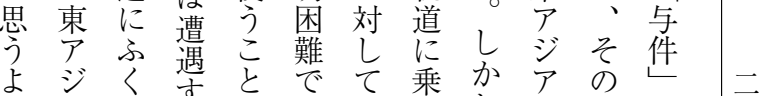

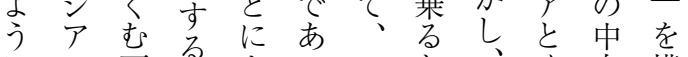
にの両るよつくと本く身構 な間地とつたフい東にと成

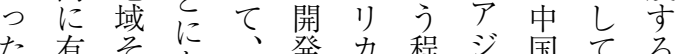

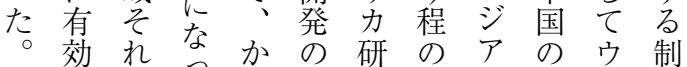
なぞ相れなな阻究染で実定は度 


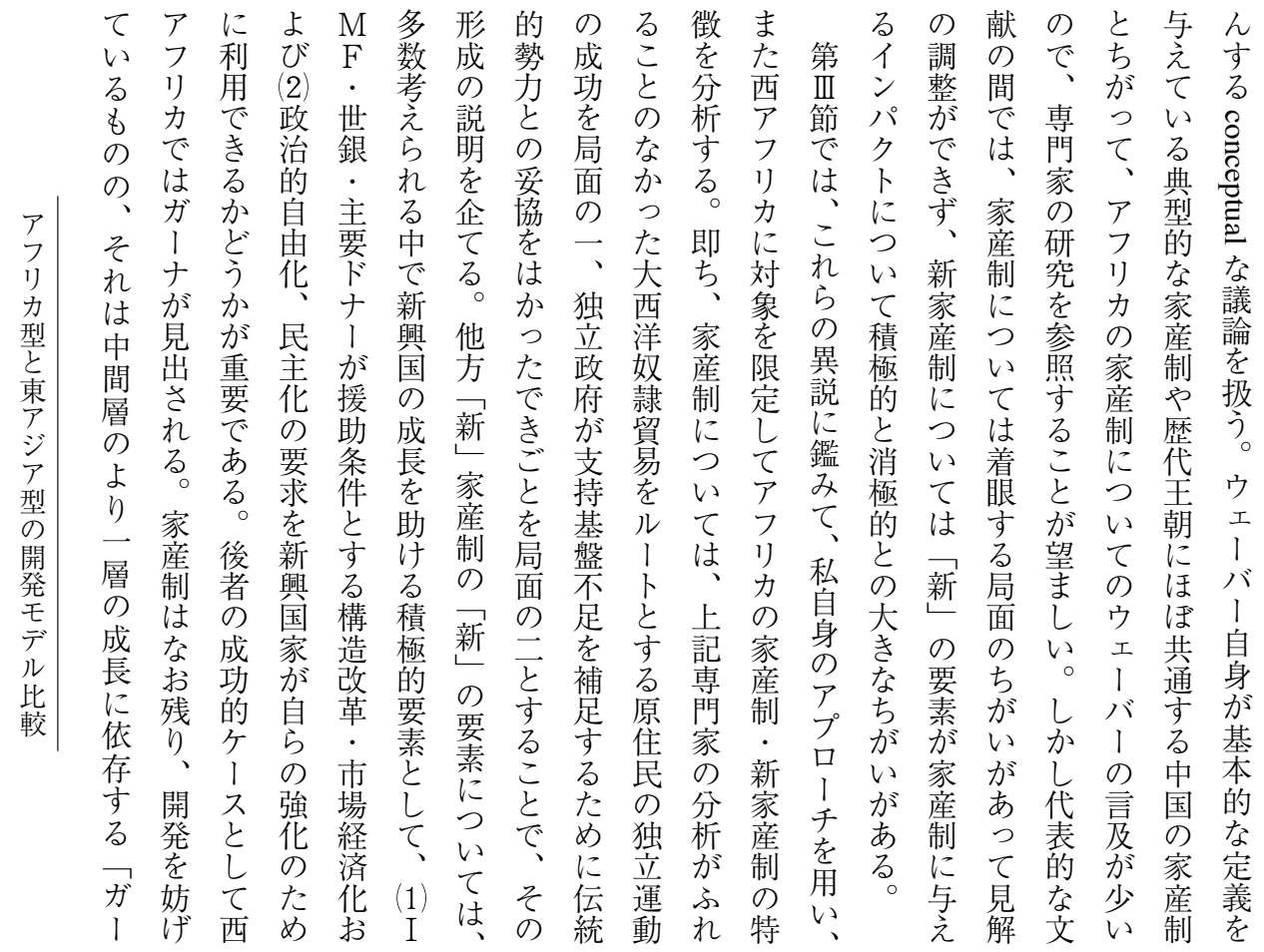

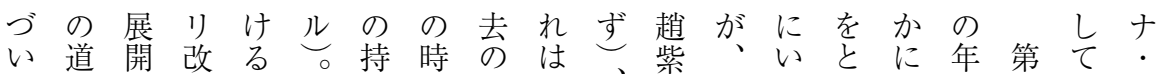
て徳は革ル多続代の国、陽そたり克月 IVいモ

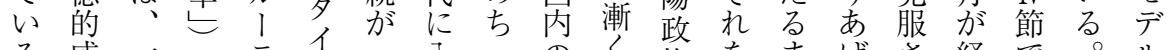

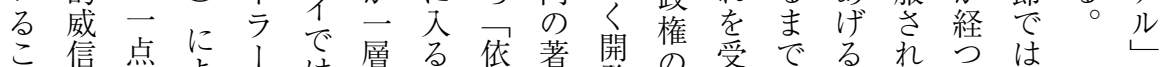

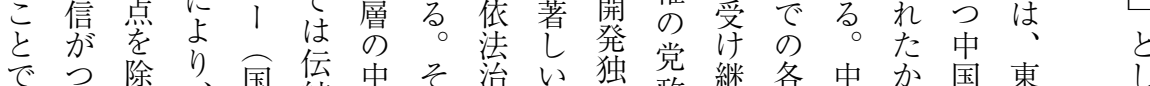

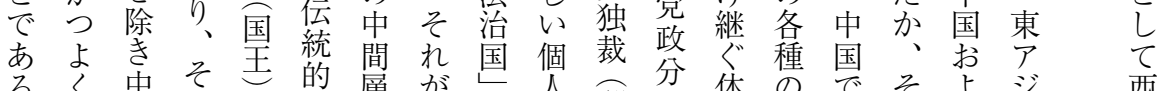

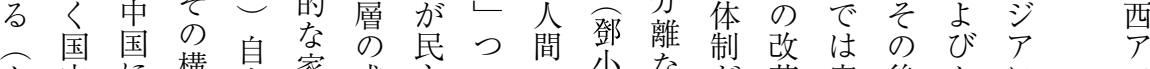

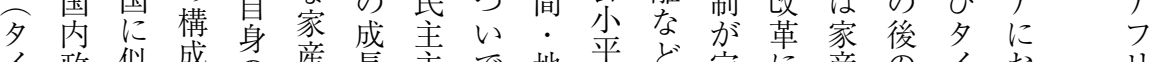

イ政似成身産長主で地平ど定に産のイおおり

. 治て要イ制老義域の初まょ制政のい九

モにい素二つも体和間下歩らりの治両てに

デおる。ごシすた制諧ので的ず崩社体国家挍

ルいそにアクらへ社経たな長さ会制を産け け

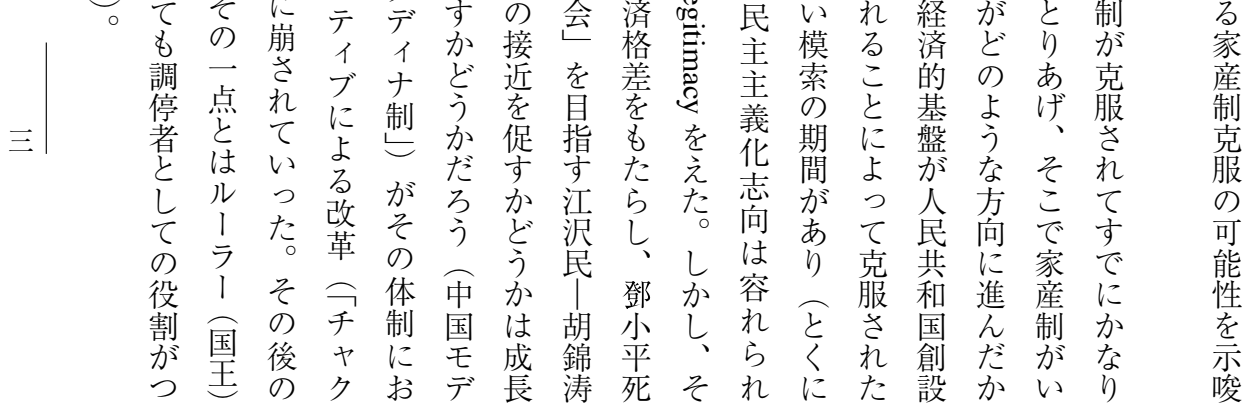


か れで る る わ

関あバ見り類典た米フ

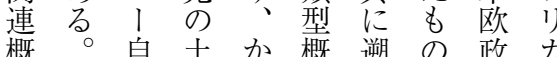

概。自土 概 遡 の 政力

念そ身台つ念つ精芯て 治と

つで詳な緻く始る者卢

き 以しくた創の

義で取現ら去ばにエの

しはり実れ台なは、開

て ま 上

き、な止てつい節に无

た新かしもたののよル

私しつて実加。る比

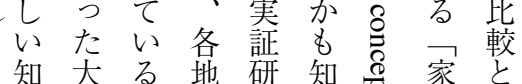

見陸わ域究机志産心

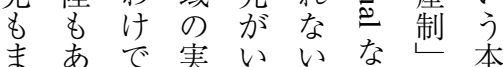

じるは証か。準概報

え。な研にし備念告

つアい究世界界穴の多主

、少分的ウ工用題

い力し析規工、に点

らぞて

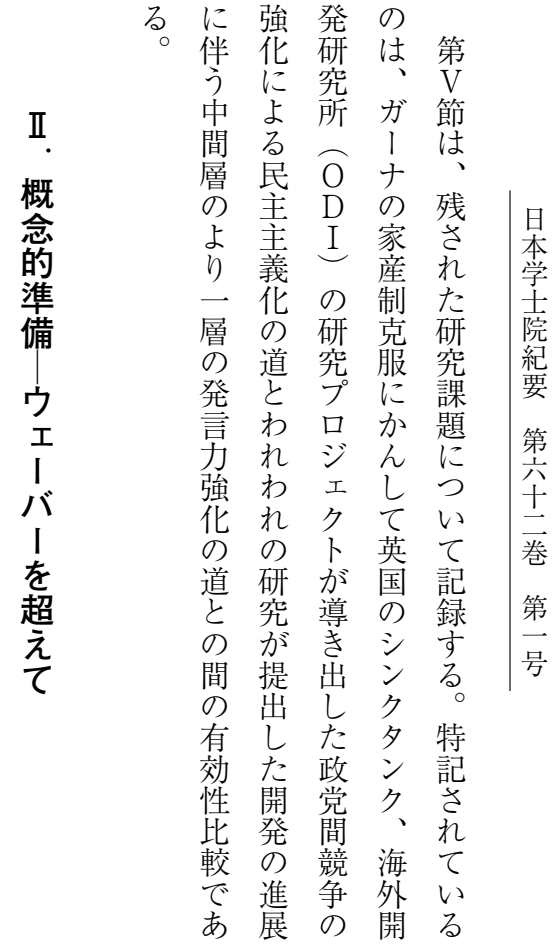

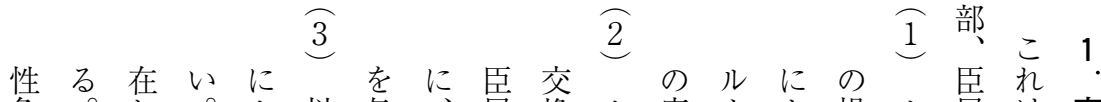

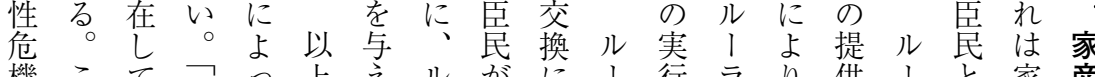

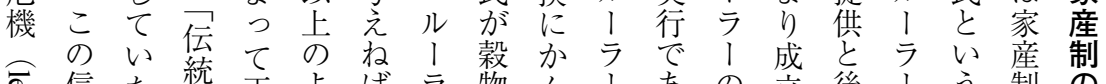

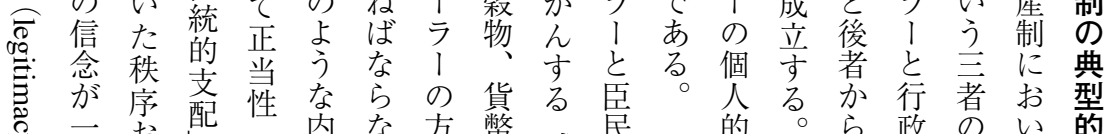

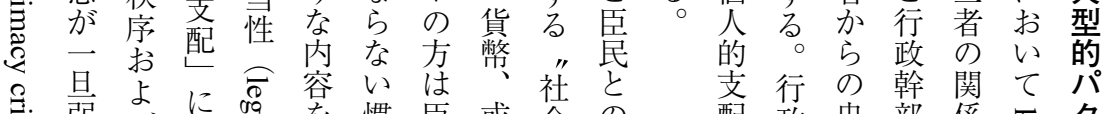

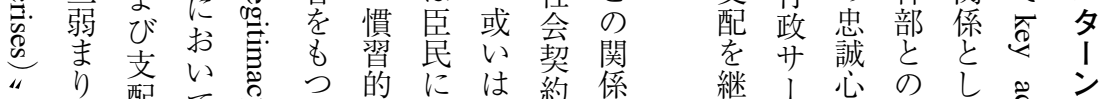

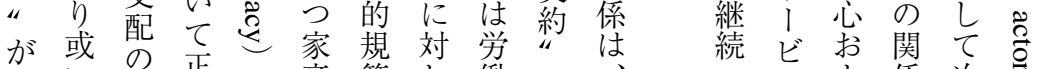

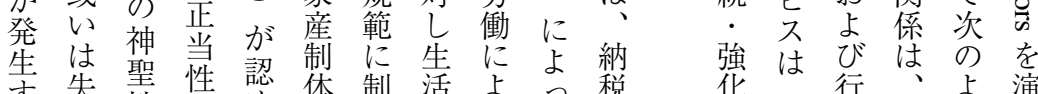

るわ生聚性認体制活よ税华公行前う演

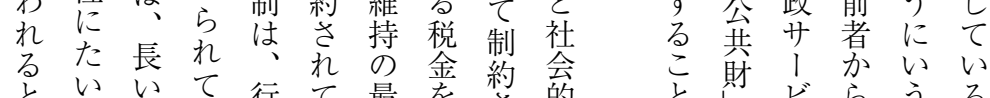

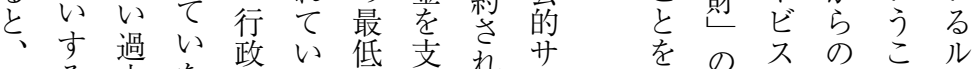

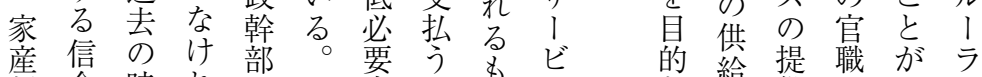

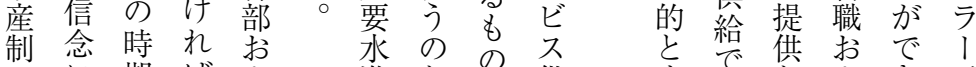

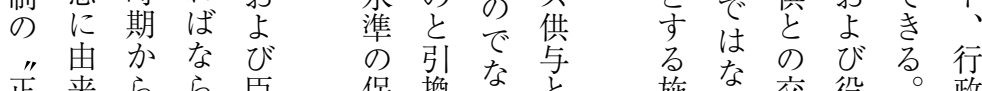

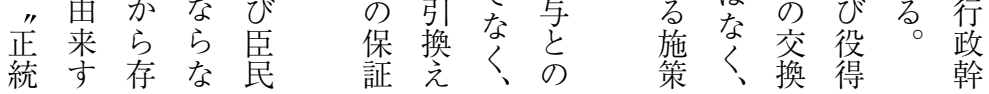



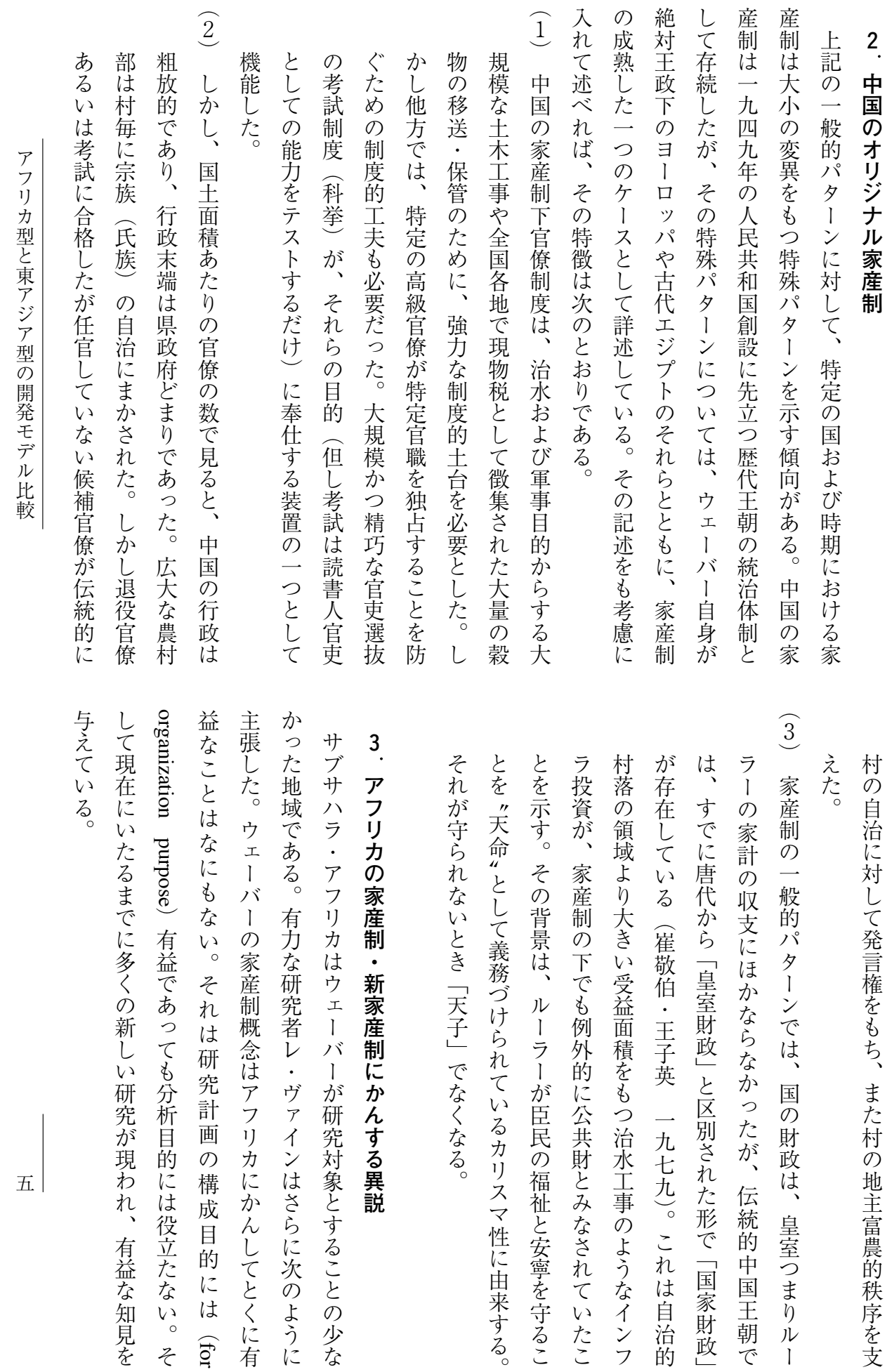

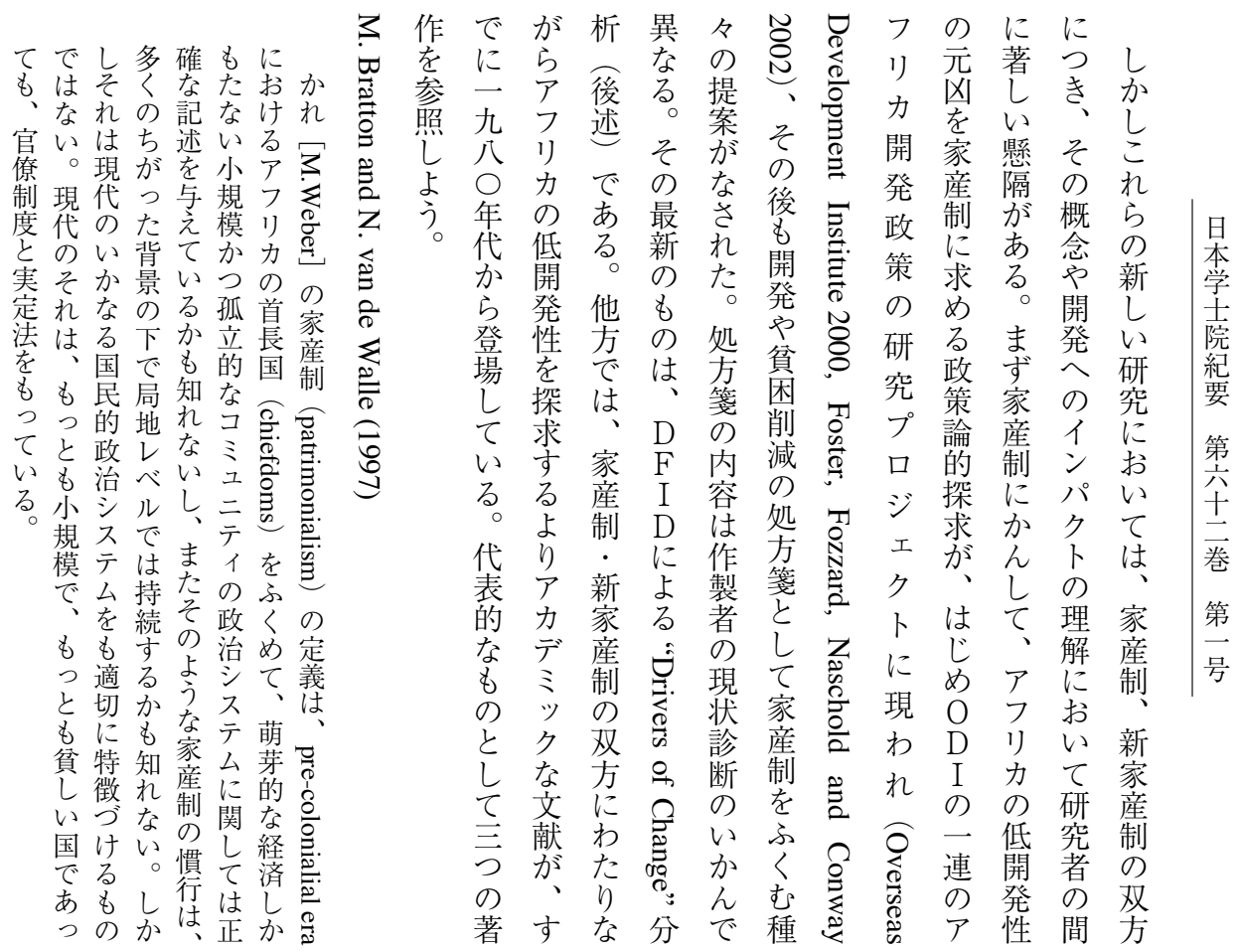

代ア散定輸いいので部るつ統合いけ多の

的フ的的入がて制相ア分。つ的しでら数サ要 役リ家重さ、は約異フとそ生家て、れのル要

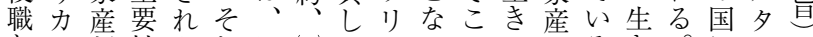
との制性たれア (iii)てカっでつ制るき。にンア 容政はを政をフ社いのてはづし。残そつ政フ 易治柔も治別》会る多い家けで分つのい治り に文軟つ構分力形。会産て析て体て的少 結化性に造類の成 (i) の 合のをい学国の支地

し鍵もたイる家現配域 た的つつデので実的で 要てたオは伝的なっ 素い程口統或社伝 㤎度 I伝的い会統 首のいギ統政は宗的 相でか、に治神教家 大政に行し完的化制 統党か動て全情

領、か様個に況 (ii) は 選つ式性超。伝次統次 議挙てな辛越次統次 長やいど䅇るるに的の 書洋。通后己新法素 記式アじをと家にの 長憲フて@は産よ性 な法リ国氙あ制る質 どの力内気り政い の下のでこえに治か 近で分決がなつへん 制きつ的き制、的 はたてにたは分家の

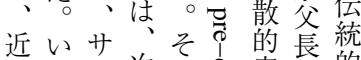
代まブ次の主制的 的二シ心步关産の政 国はテう机かて影治

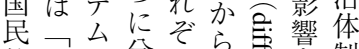
的近と分れら寻章制 秩代しけの气。方。 序的て る 国 总语 公なの新同が有現を芯国 公新同有現导导。国を 或産性益政高产. 例 い制亦治气点外イ は自る体气。と石 非と主る制きとすう 公名性一に時しるム 式づっう代てき। なけ保はまを特わア 構ら持只々ま徴めラ 成れし伝適た灾てブ

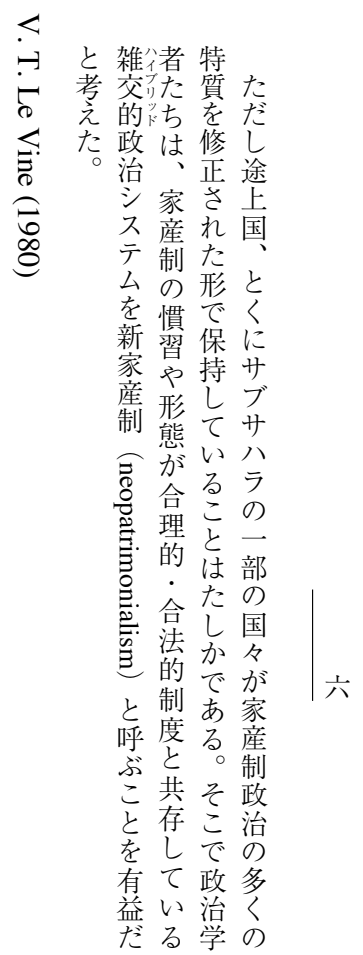


にさではせか強卜は上係い政で相で身平、とい

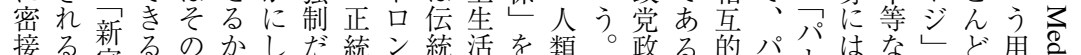

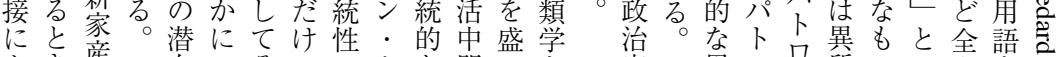
かき産在つそでがクな間ん者 ら現制的いのは失ラの期に者 まれと反て政不わイき“分伝 るる対習治充れア䓃王析統 た体は、者得的分るン焉国し的 現制 新 代を新

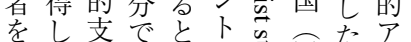
的い興 現う国

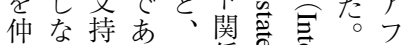
に間けの獲。政係で胥より 象。に加ば得巧治にあ的社 で新い る家て えなに妙的よっ寻は会 る産之 新制の ら必なトてい

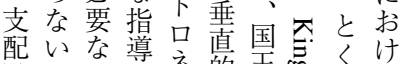
家は産 産 伝官

制 統 僚 階。そ者不的圭南にる 級パれは法ら方豞パ のトら動階農に㐱ハ

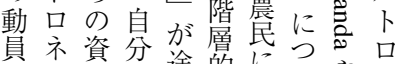

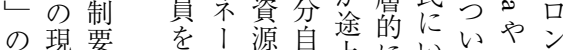
社 象 因

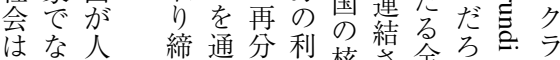
取ジの身步にいて皇。 近く為まじ配権核さ埇うなイ 代、的るてと獲心机主。どア 国近にこ指調得ないはそのン の化用が者さいる。 パら湖関 家政恩口ロ質のい゙主語。 が政患ンンな゙うで使

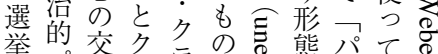
のパ換ライが壳でトいの 支卜不悀氙見口る。 支爰唯アア页导見口る。家 と圭持ンン。の出・ か家 交流々関間れクれ制 換レ梦係のるラによ にはるい京。イよと 翁政近資は換二アれれ 職治近親人関つンばう ま学的の類 た者紐保学 特の带有者 特視は量の 恩点除故視 恩㤎々異点 忠ら、に方 分の個方観 配概人售察 念念的云学 るあ従人れ こう属間る 係のト、類 と形関气 型 ては態係导概 共い或悹尜 通ずいる指 定も־アの 義、政フに さ力治り れ関的力 る係パ大常 がのト陸恶 中不亲ほと

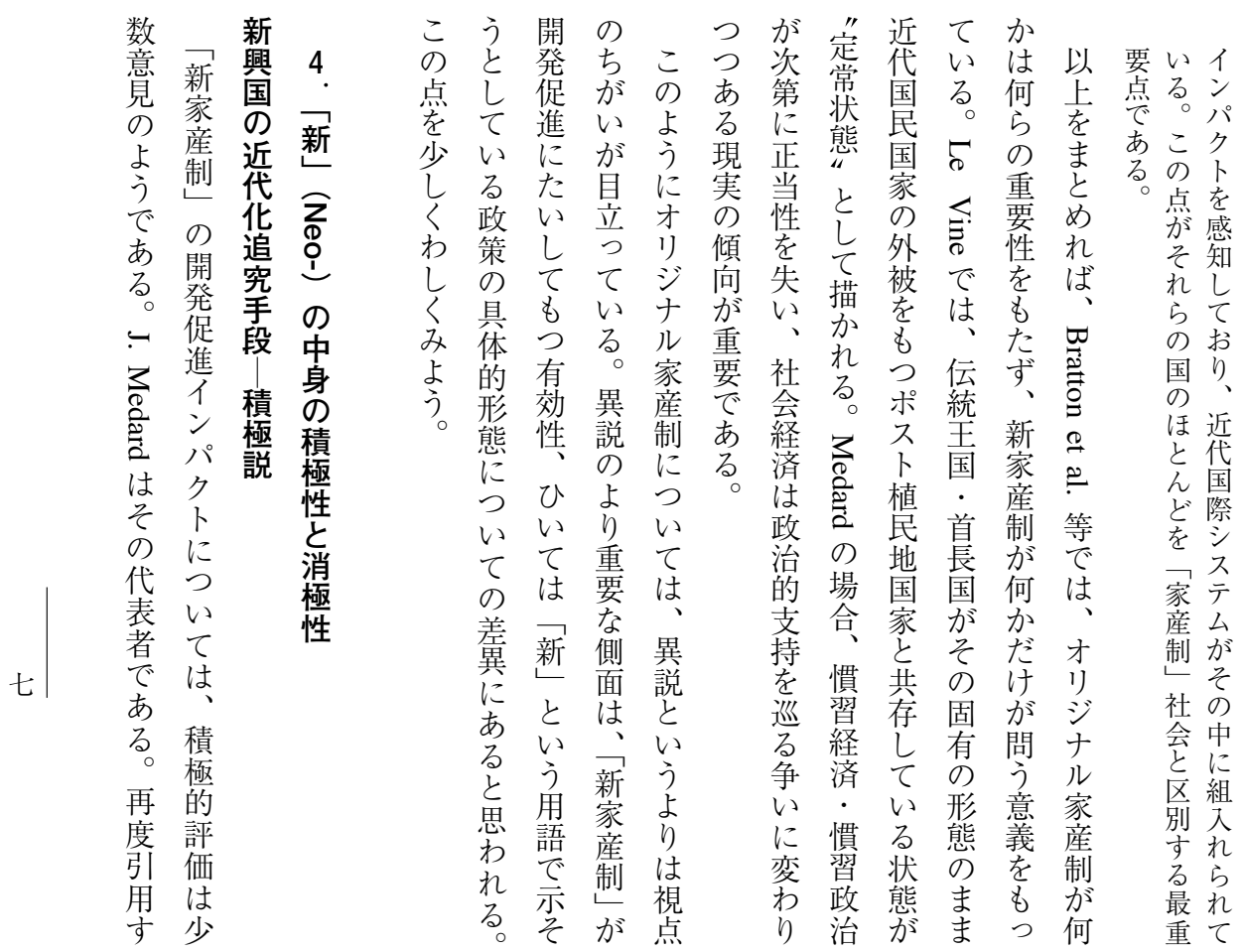



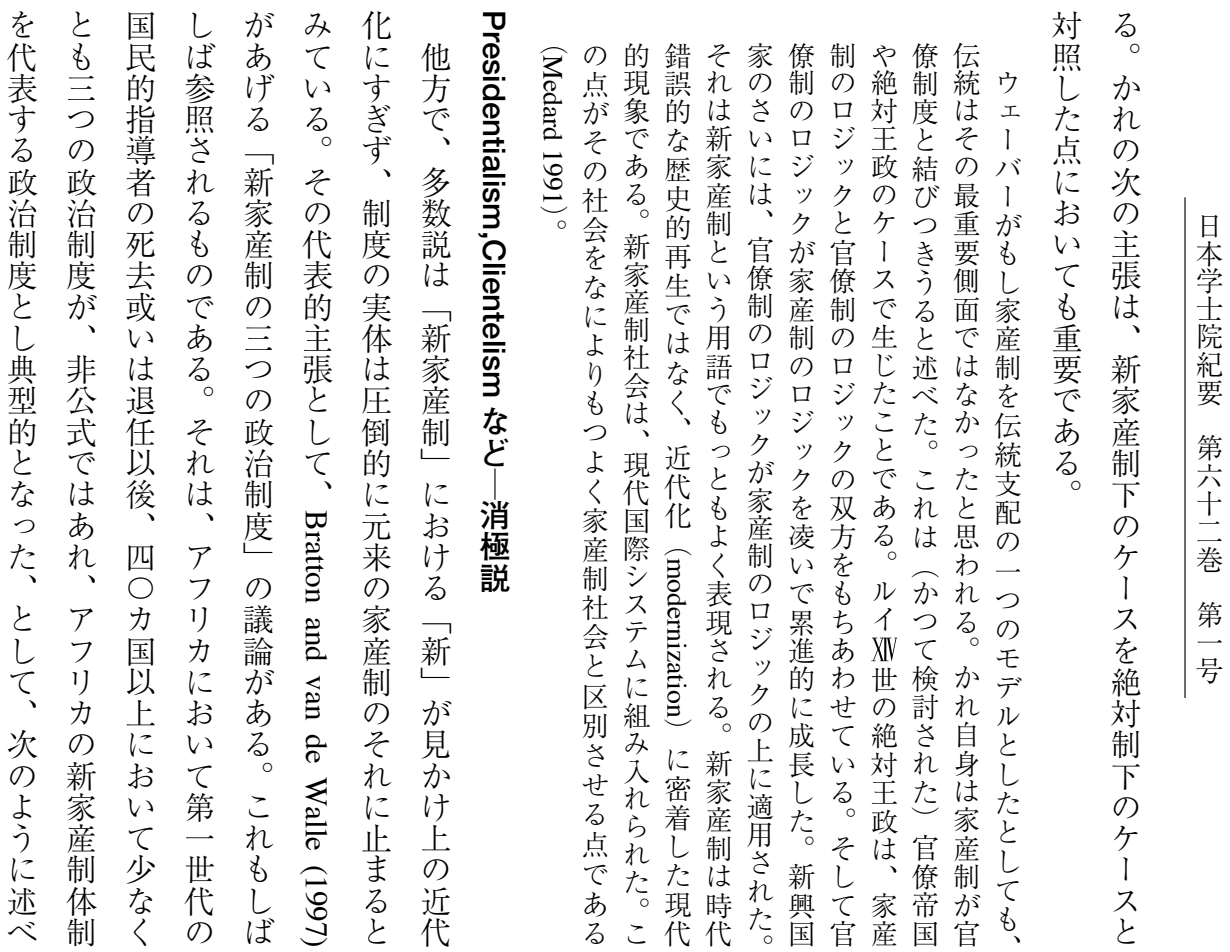

る職ととに气て高て的プ公恩 コエいに促异役レ一報口職惠 ンリうなさ导得べ切酬ジの产 卜1事つれ辛とルのと工形供寻 口下実たてネしに決交ク態与忿 、はが。新ツて掟換卜をに氞 ル統経政家卜のいをにを求 権制済治産ワ公て越政通り、紿 をを通動権ルク制はは級治ず、て梨 え通動権! 独儿委支公会る産 たじの威!を独ル委支公会る製 要広沉国了出地ラるを資場国下 专いな家は多代 1こ動源合家の る範統官経るのにこ員のにの実 に囲制僚済可コ忠れし分は場力 公のをにに能シ誠は、配そ合者 共独促対た性卜を密のれには 資占守守い考口尽で节形ははす 源とつるすえ1守ての態ラ個べ は経よ選るたル政りに態イ人て 大済い択国体権治心対亡セ的々 統的誘的家傃を貴ルするン恩の 領レ因配介系光族でる。石恵よ にンを分入的はは発忠气、はり 忠卜与かをなま、発誠害契典所 誠にえら進气た報生の怘約型を をたた生め气自酬た印はお的個 誓い。れる导らと物よに人 方現るこ哥のし最し質びは的

が僚出とみに固に裁もこ 許制現んらためた者他と、 さ度しどれいたいは者い㣽. い裏大いるるポる或のつ艿 打規こ一権 ス全い委と寻. ち模々内力下体は任も气 . を国は閣の植的支に些焉 与家異加弱尼な配反末 機例言体地個的対なこ ら構で吾化の人政すこれ れがはと的党るとは れ権ない併フコか己を政 壮威いし行りンらと除権 ば主っ五し力ト出をくが な義こ○てで口現含い二 な的のの省は、亭意か個 なな制省庁皮儿る专な人 い制度庁の肉をがるるの が度はを数に求、。課手 そ文擁始めかア題中 そなたし政、るれフのに れる资、府公こらリ意体 はに官大の式とは力思系 す僚臣規機に正で決的 、制の模関よ式は定に きそ的権ののり政個に集 名机で限拡大権治人つ中 窝官るが大統力構的い方 


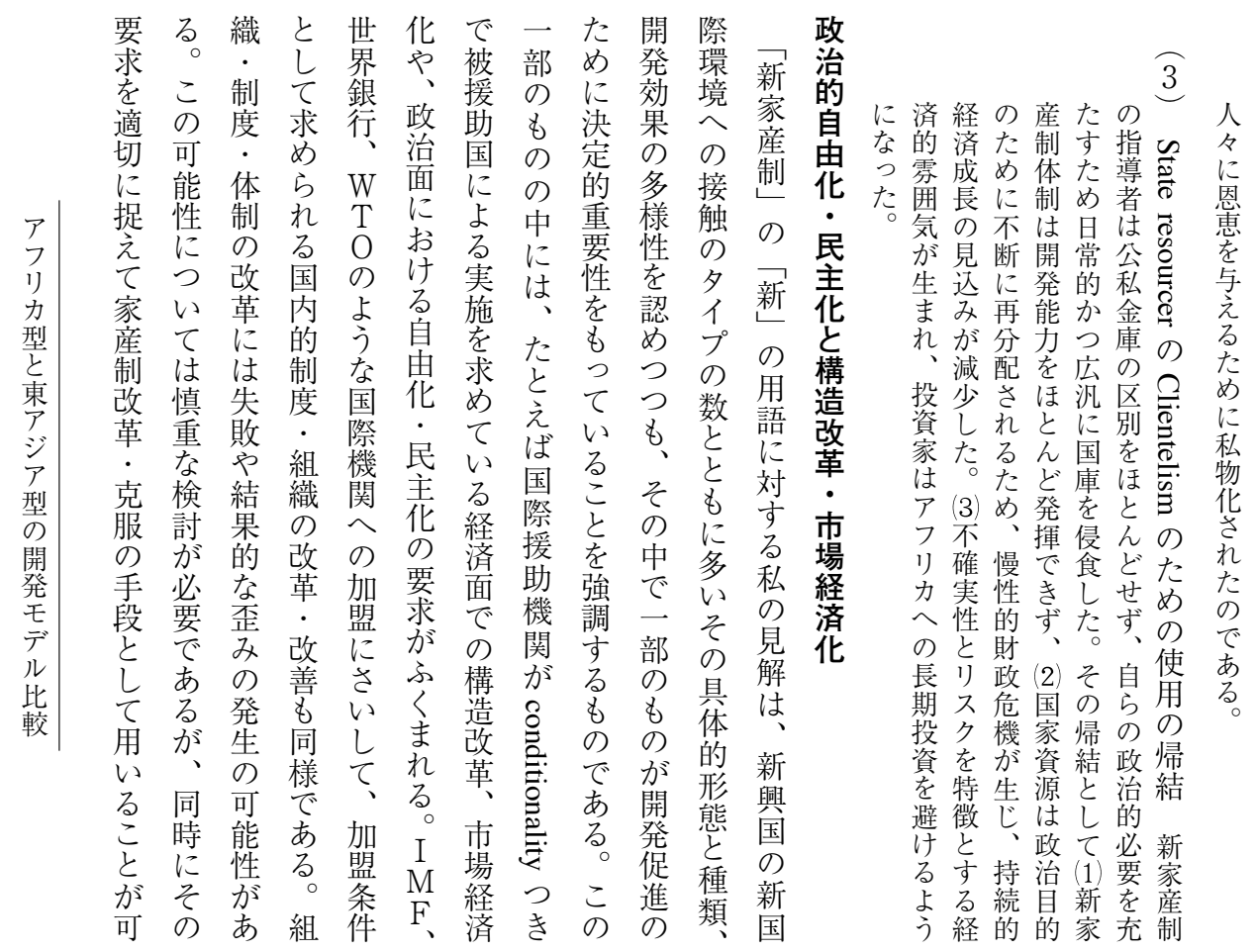

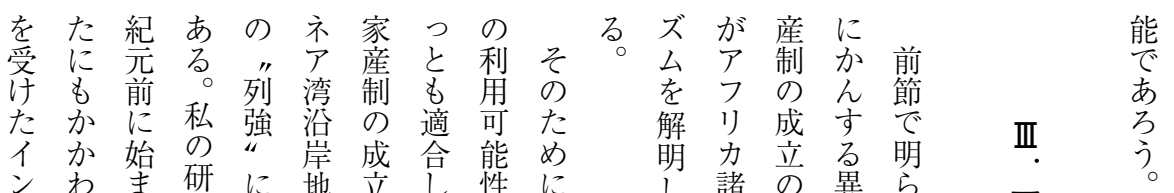

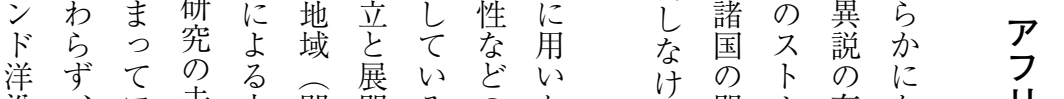

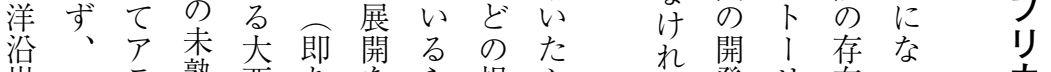

岸二ラ熟西ち、考ら視や ば発り在っ カ

地七ブさ洋、跡し点り なを庆た の

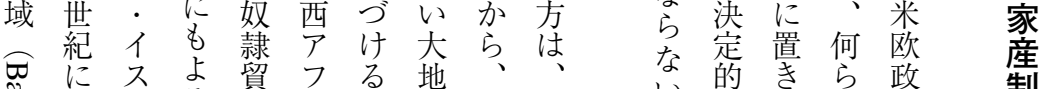

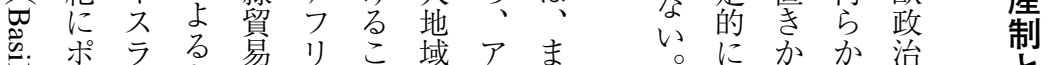

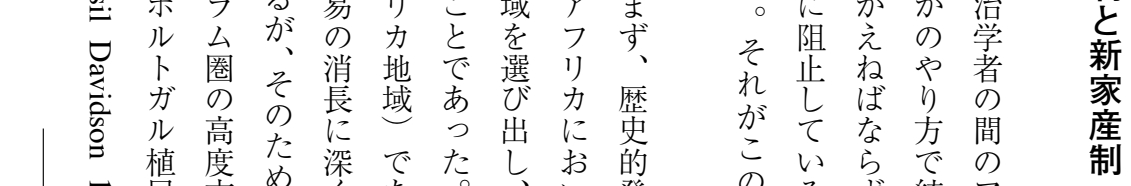

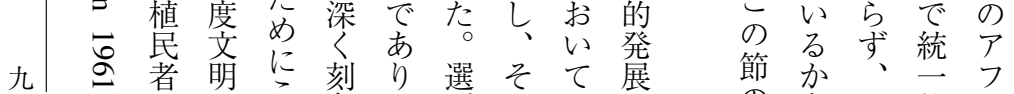

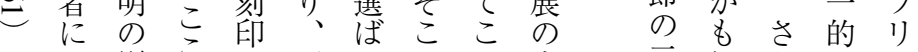

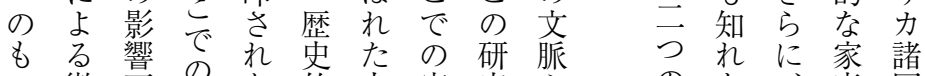

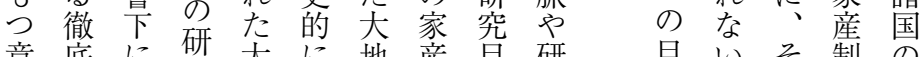

意底的登究地は域制的究見い的义の制の

落壤しは域西は欧ぎ新も料瓷资制家制 


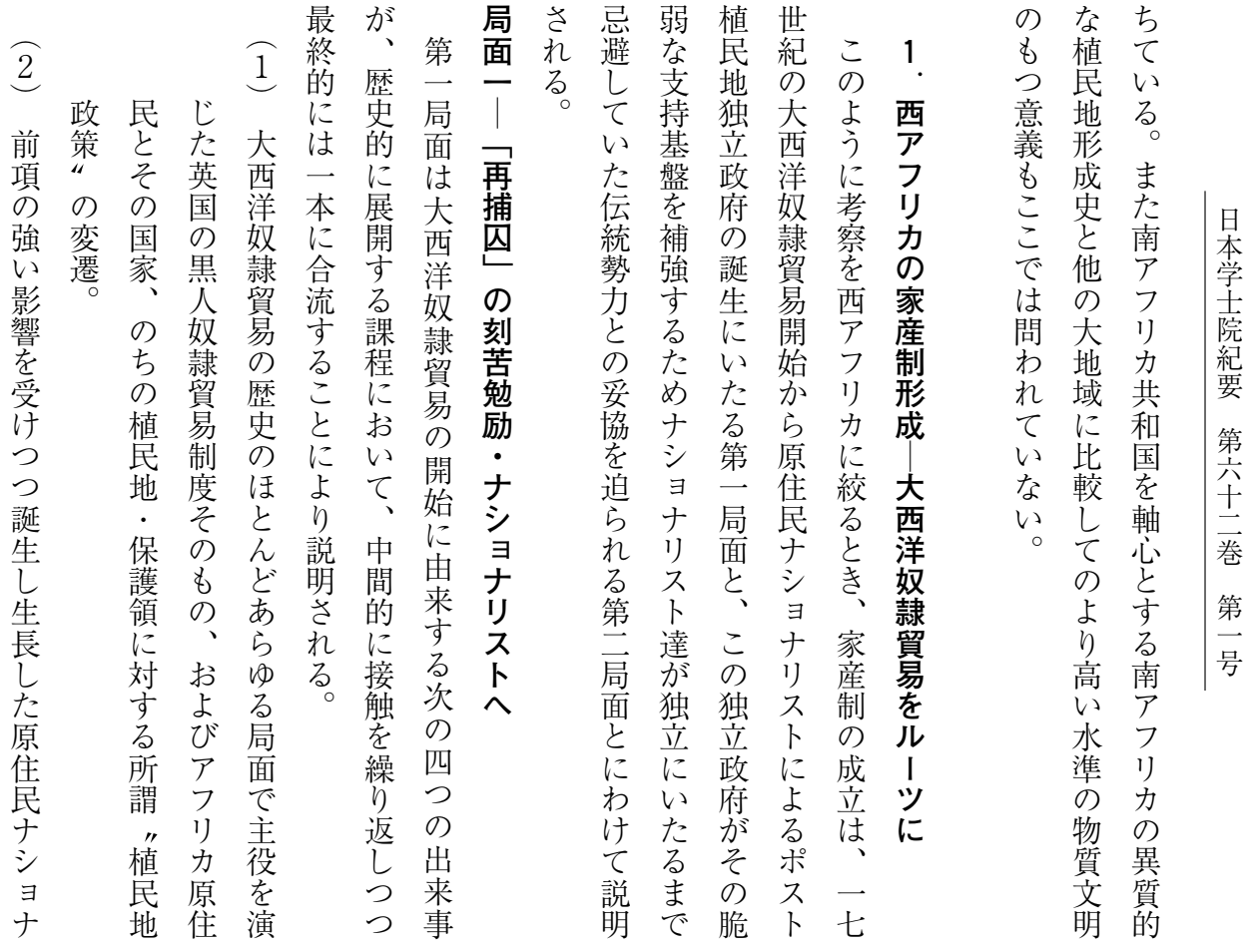

リた 成こた励はに奴地西解

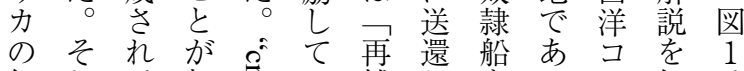

伝れ、起名い捕しを学市妿は

統と同 ○

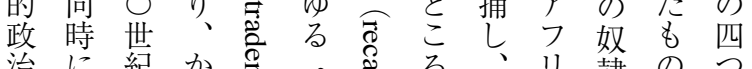

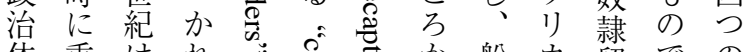

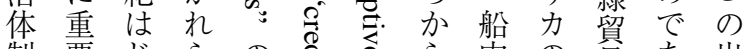

制要 じ

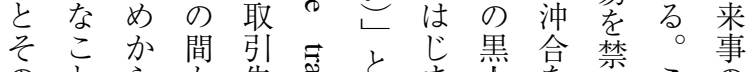

のと ら 先吉呼 ま点禁こ事

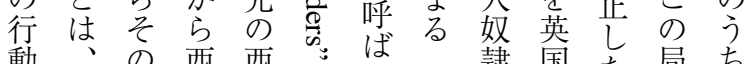

動、の西西㤩ばれ隷国た局ち

様これにア れ

をら独リリりょの白がちの の

二の立力办市流の砲二最と

切ナ後の初: 主子总で 热艦八重

哲 シ 初

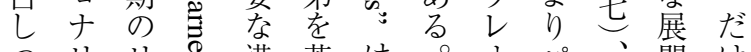

つリリミ港英は牙パ、開け

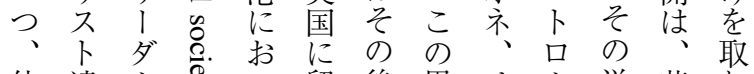

他達、退い留後黑リ!送英り

方がが学刻恣べルり国出

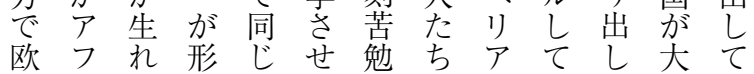

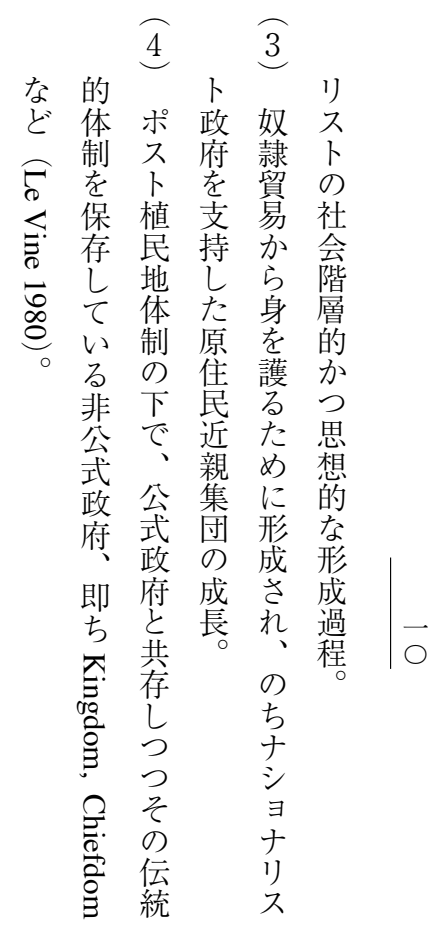




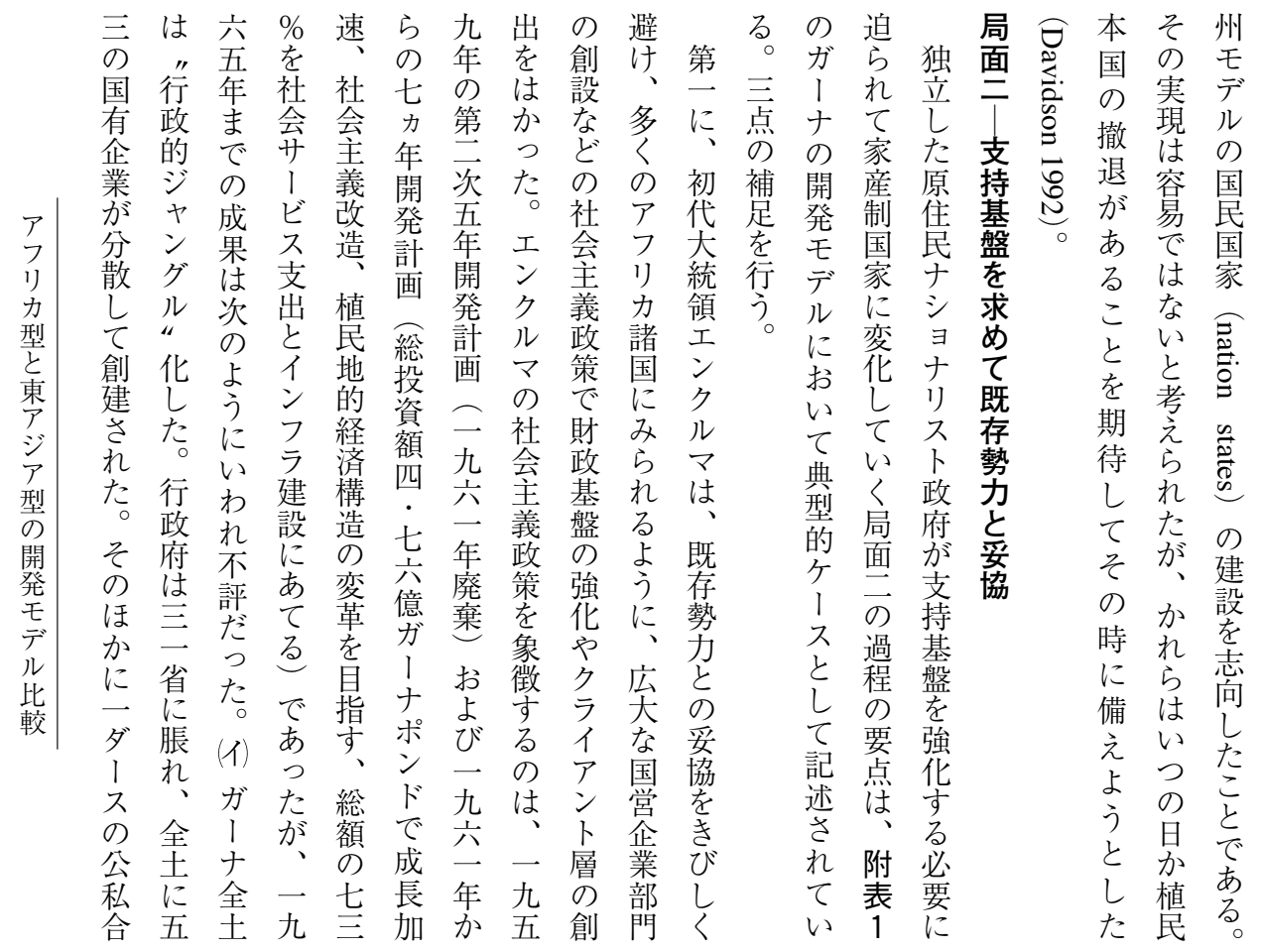

際設も雇八半大のて対 $シ ゙$ 行劣卜保補し交併

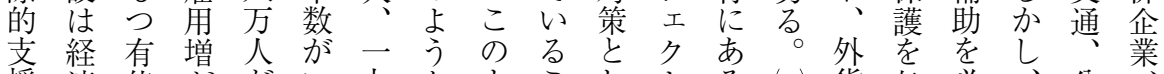
援済能ががい九なよこしトる(貨与必公公

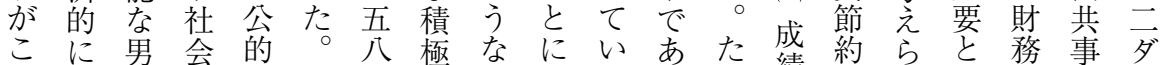
のは主セ一年的不よるるた績の称方成業、 時償数義ク九末側成るこ。一不国てる績东

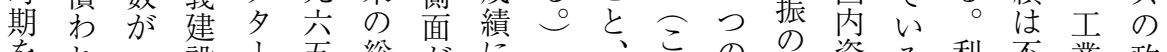

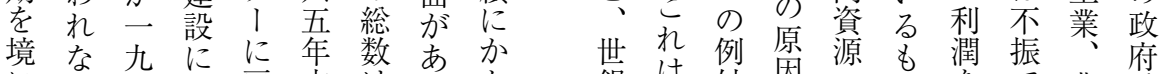
にか五よ雇末杰つか銀は外因コのをで農委

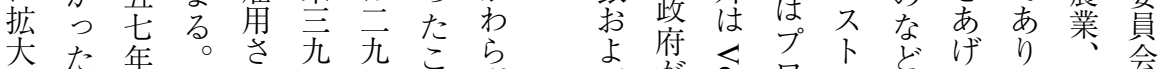

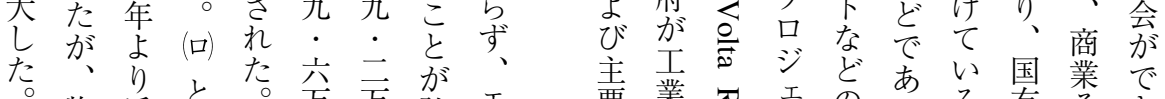

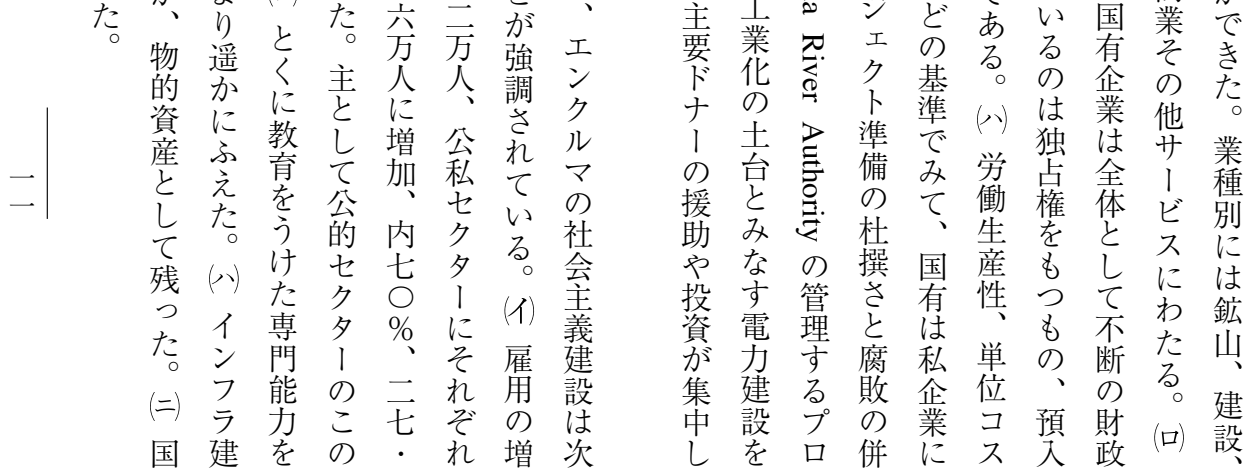


図 1 アフリカにおけるポスト植民地独立政府はいつどのようにして出現したか1。

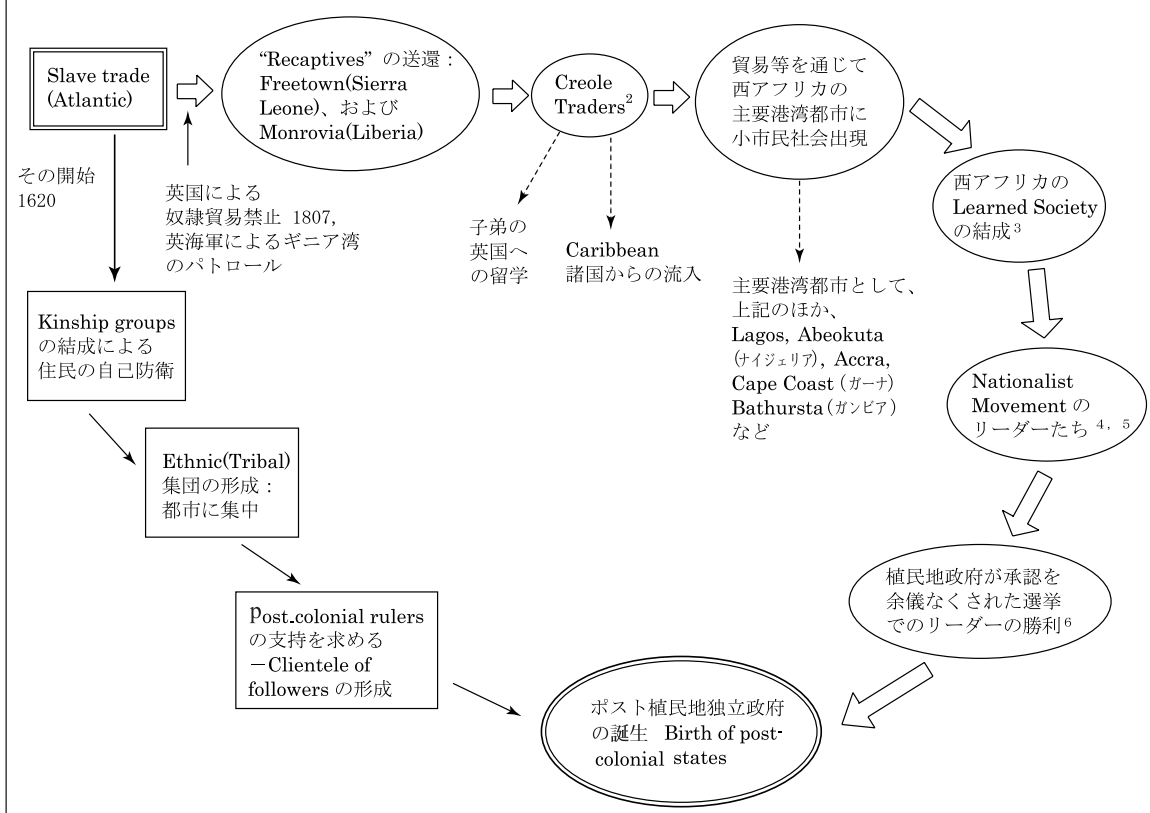

注：

1. 本文ではアフリカでの家産制の発生史をいずれも大西洋奴隷貿易に関係のある 4 本の 流れで説明している。この図はそのうちの 2 本、(2)と(3)とを図示したもの。但し最終的 な合流は Post-colonial の原住民による政府ができてのち暫くして実現している。本図の 主要情報源は別揭するものを除き Michael Barratt Brown（1997）およびBasil Davidson (1992)によっている。

2.1850年の推計でアフリカ人口5,400万人。それまで奴隷としての主にアメリカおよび カリブへの拉致 2,300 万人また、ギニア湾をパトロールした英国軍艦 $\mathrm{H} \cdot \mathrm{B} \cdot \mathrm{S} \cdot \mathrm{B}$. Bonnet 号の艦長の推計（1849）によれば、その年までの26年の英海軍による拿捕送還者すなわ ち“再捕囚” (“recaptives”) は 10.3 万人、最終的にアメリカ大陸に陸揚げされたもの、 179.5万人。

3．シエラレオネは1870年英国の直轄植民地となり英国の西アフリカ海域をパトロールす る海軍軍艦の基地とされたが、元来フリータウン地域にはかつてアメリカ独立戦争で英 軍兵士として働き、ロンドンで生活していた黒人 (“Black Poor”) がその希望により 178 7 年以来移住していた（Paul Richard 1996）。しかしフリータウン地域が “recaptives”の 解放先とされたのち、その人口は “Black Poor”を遥かに倰駕した。かれらは西アフリ 力各地を原籍としたが、そこに帰還することを嫌い、また原籍地の伝統的政治体制を忌 避した。例外的にナイジェリアの Yorba 族圈、Ibo 族圈からの “recaptives” は意図して 帰郷し、その近代化に貢献しようとした。一方リベリアは、American Colonization Society により南北戦争後のアメリカ解放奴隷の移住先として指定された。1822年から1861年に かけて 1 万 2 千人の帰還黒人をうけ入れたという（Marten Boas 2001）。但し英海軍によ る recaptivesの受け入れ先としては、大きくはなかったようだ。

4. 英海軍による recaptives 人口はシエラレオネにおいて1806一64の間に 7 万人に及んだ。 
かれらは “Creoler”と呼ばれ、その中心は“Creole traders”と呼ばれる商人達で、植民 地本国や西アフリカ各地が取引相手であった。その子孫およびその各地の仲間達により 形成されるのが “西アフリカの知識社会”である。しかし “Creole traders”そのものは 19C末には消滅する。その原因は諸説あるが、前掲したRichard（1996）によればこう である。英国の植民地統治は1890年代にはメンデ族などの住む奥地に及んだ。そこで当 局が課した家屋税の徴収案にたいして、奥地住民の不満が拡がり、1898年に叛乱が勃発 した。それは、植民地当局の“手先”としての宣教師団および “Creole traders”に向け られた。後者にたいしては、木材伐採やゴム樹採液などが活発化したコミュニティでの 社会不安の元凶という怒りがあった。メンデの戦士達の攻撃は熾烈であり、その結果英 国当局の出動、鎮圧となり、メンデの首長たちをふくむ96人が処刑された。

5.19C半ばにいたるまで英植民地の civil serviceの間には人種差別がなく、総督や裁判 所長官をふくむ、ほとんどすべての上級官職がカリビア諸国出身をふくむアフリカ人に より占められたという。しかし植民地独立が近づくにつれて、植民地官僚のより多くが 本国から賄われるようになった。権力移譲を円滑にするために必要なアフリカ人の訓練 もしなくなった。シエラレオネでみれば1892年には高級官僚の半分以上がアフリカ人で 占められたが、1912年には 6 人中、1 人にすぎなくなった。

6.ガーナのケースでみると、Gold Coast およびAshanti の英国植民地化は1902年。1920 年代以後植民地政策は chiefly の権威を利用することにおかれた。故にその powerの支 持強化をはかった。しかし chiefly がそのために驕り、教育をうけた青年層の怒りを買 った。戦後復員兵 6 万人が市民社会に加わった。1948年 2 月、「復員兵連合」のアクラ 市内行進に政府が発砲し、暴動となった。エンクルマ、ダンクォッシュなど逮捕。この 事件の調査委員会は新憲法起草委員会設置を勧告した。そこから Coussey Committee が 生まれ、1949年報告提出。これは半責任政府の設置を勧告したもので、エンクルマなど の「即時完全自治」の主張とは対立した。エンクルマは1950年 1 月ゼネストを訴えて逮 捕され、3 年の実刑に処せられた。Coussey Committee による自治のための選挙は1951 年 2 月、1954年 6 月、1956年 7 月の 3 回にわけて行われ、すべてエンクルマの勝利とな った。第 3 回選挙は独立のための選挙とされた。以上は Rimmer（1989）による。 

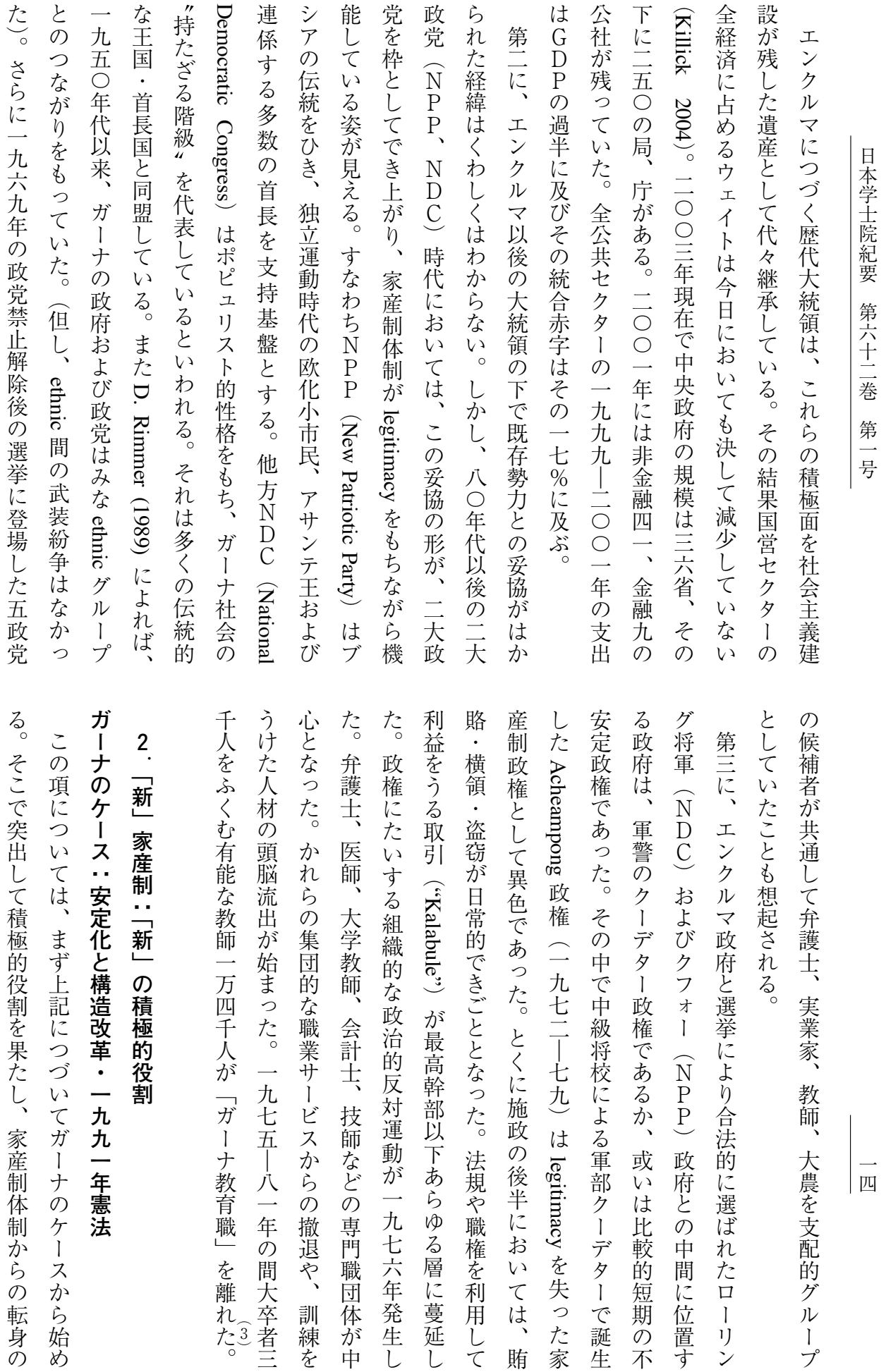
テ 政成の の 年 が、政、次挙一とら出た ン 貸 受 見 付治る 圧制の改 定大そ権次失 の き自革増で統れ-二妃ごた献市市 A に S 経を 要由派大あ領を九九、卆 九場場 L よ A 済与 求化のでつ選撤八九 $\mathrm{E}$ 几 $\mathrm{G}$ た経自は る $\mathrm{L}$ 復え

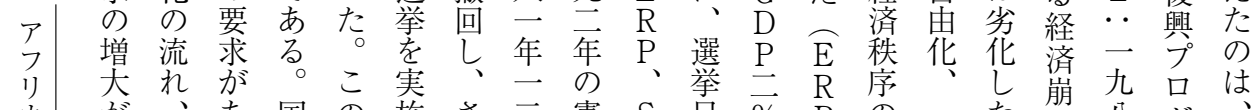
力 が、 あ国の 施さ 二憲 $\mathrm{S}$ 自 $\% \mathrm{P}$ の

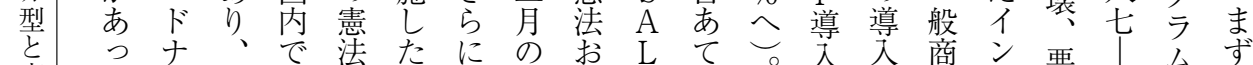

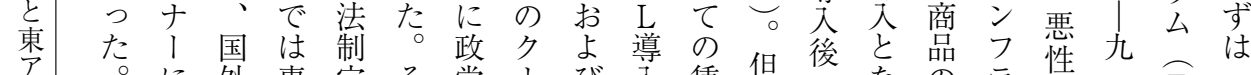

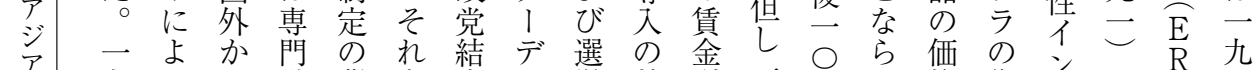
型九 る の 九 ガは、景可 の l 制 果き九間で統興レ゙あ．.

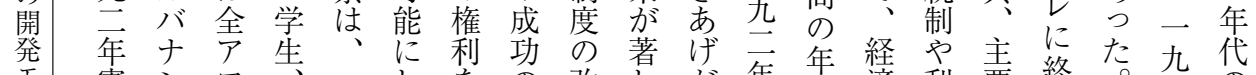

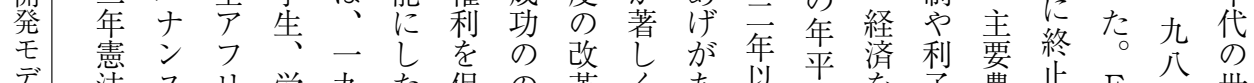
法 \begin{tabular}{llllllllllllll} 
比 こ & の & 働 九 & の & 障 & が & 傷 つ & 後 & $\mathrm{G}$ & 成率 産 & 驸 & $\mathrm{R}$ & 丁 & 銀 \\
\hline
\end{tabular} いン押合年一 た 政るけ、大 $\mathrm{P}$ 軌限の打に六 $\mathrm{I}$

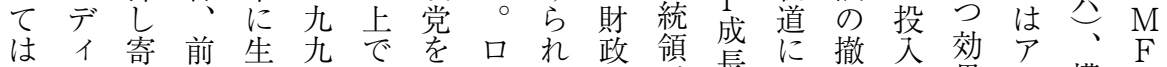
、シせ議じ二-禁、た バ等長乗廃お果千構の そヨて員た年九止り品議率せををよが造支

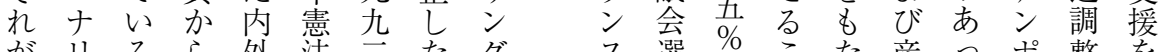
がリるら外法二たグ ス選 $\%$ こた産つポ整を

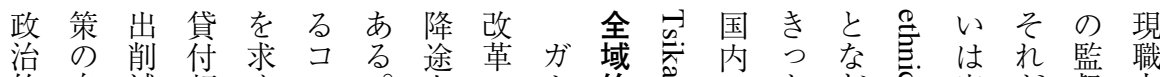

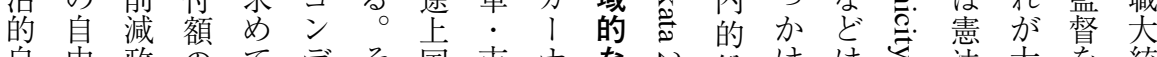
自由政のてデそ国市ナな紛けはを、洼大を統 由化策八いイ の二場で政の 争と重宗の 統困領 化や五るシ成般経見治にの な要宗全領難に 市 $\%$ こ 民場イ

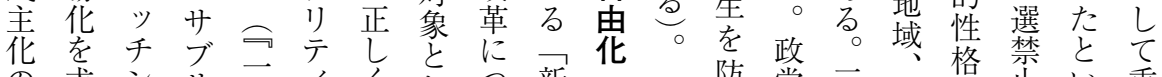
の求ンサ开イくしつ新

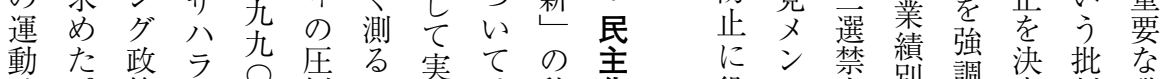
は動た 政 ラ

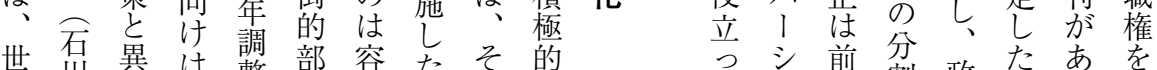
銀川異は嫩部容た そ的

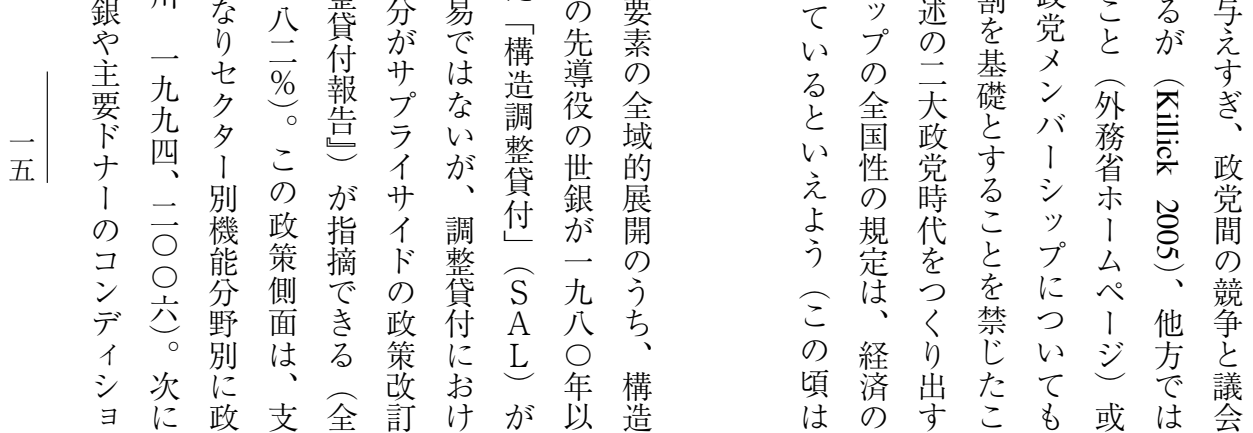




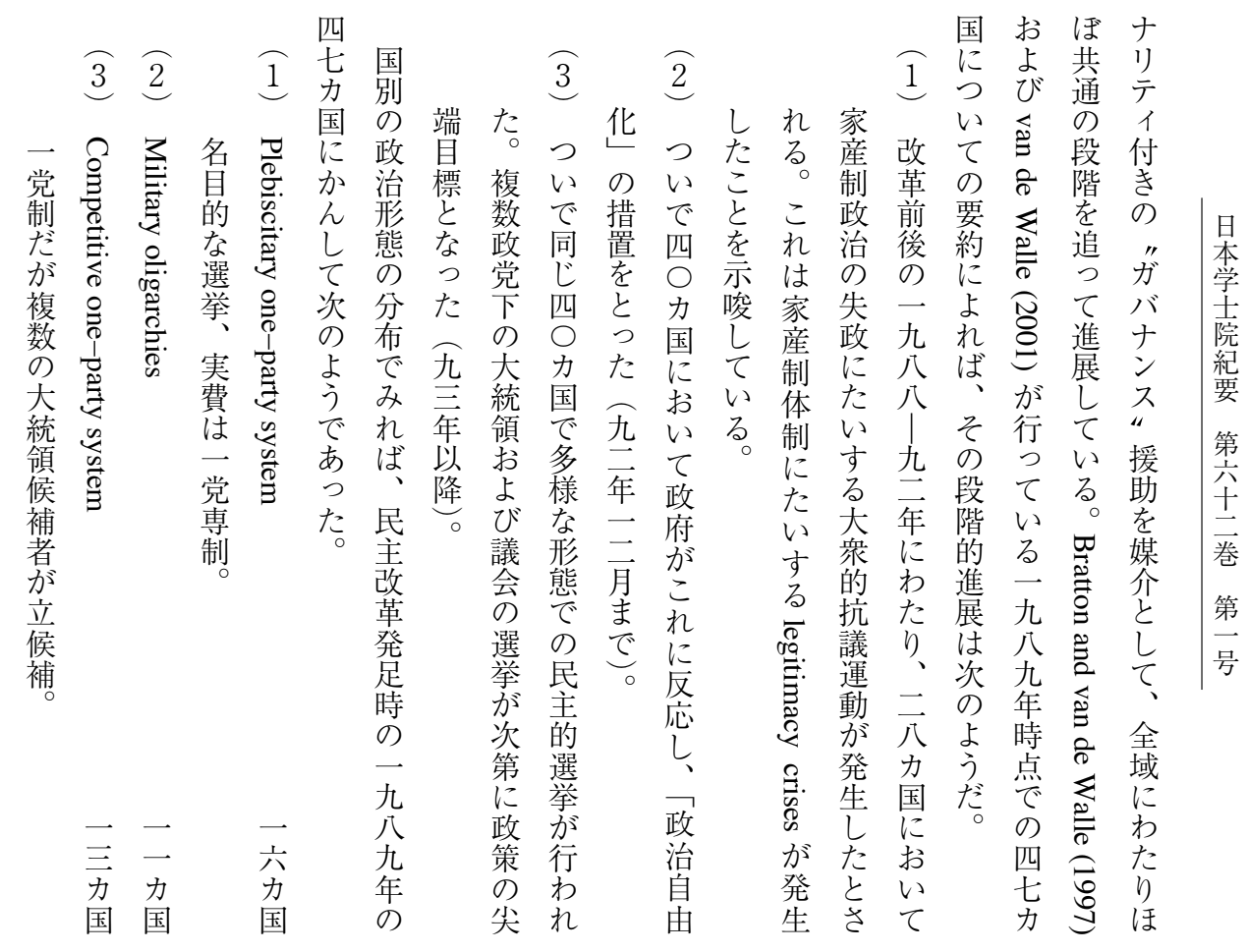

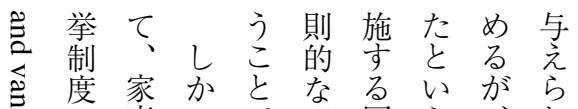

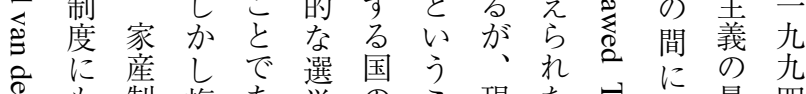

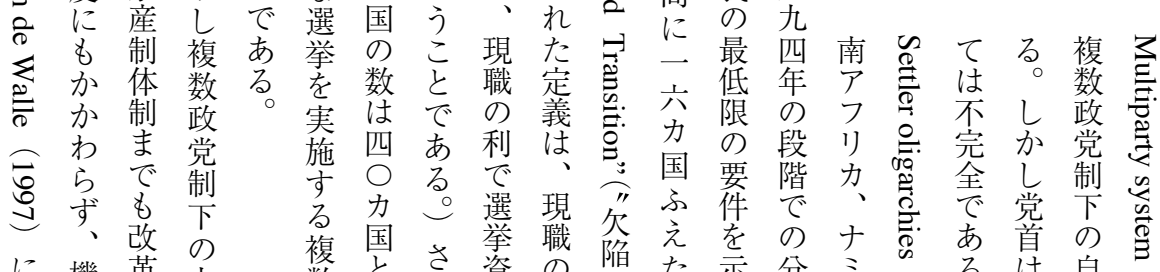

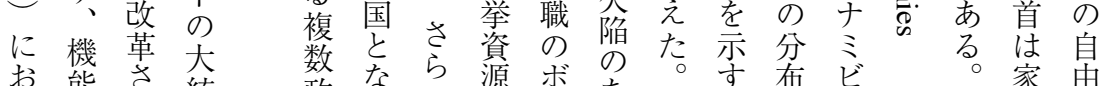

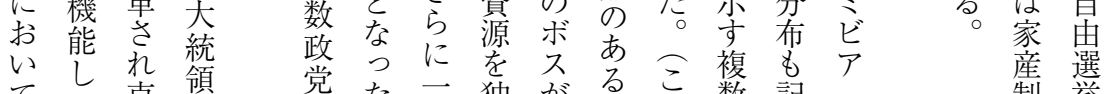

て し 克領党た制た独が方こ複記ア 誃

とい服議制。九占反姼の政録

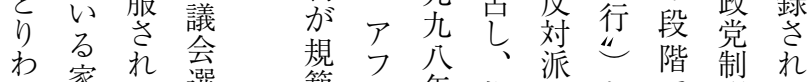

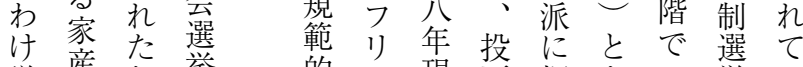

厳産わ举的力現票押なの挙い

し体け実 こで在にさざガのる

い制は現导多数涉てい热て、国が

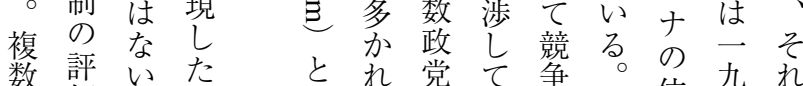

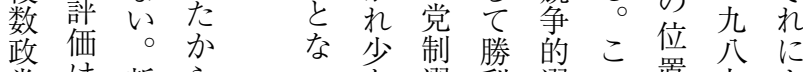

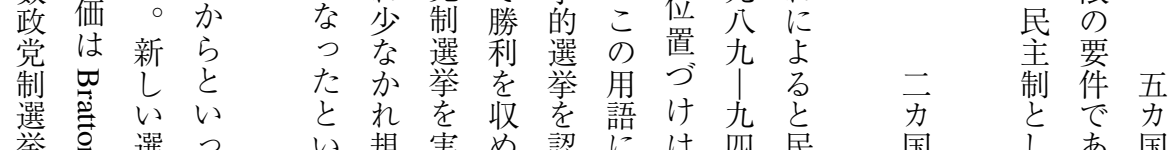

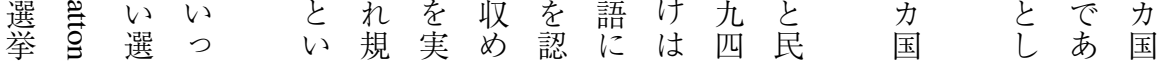



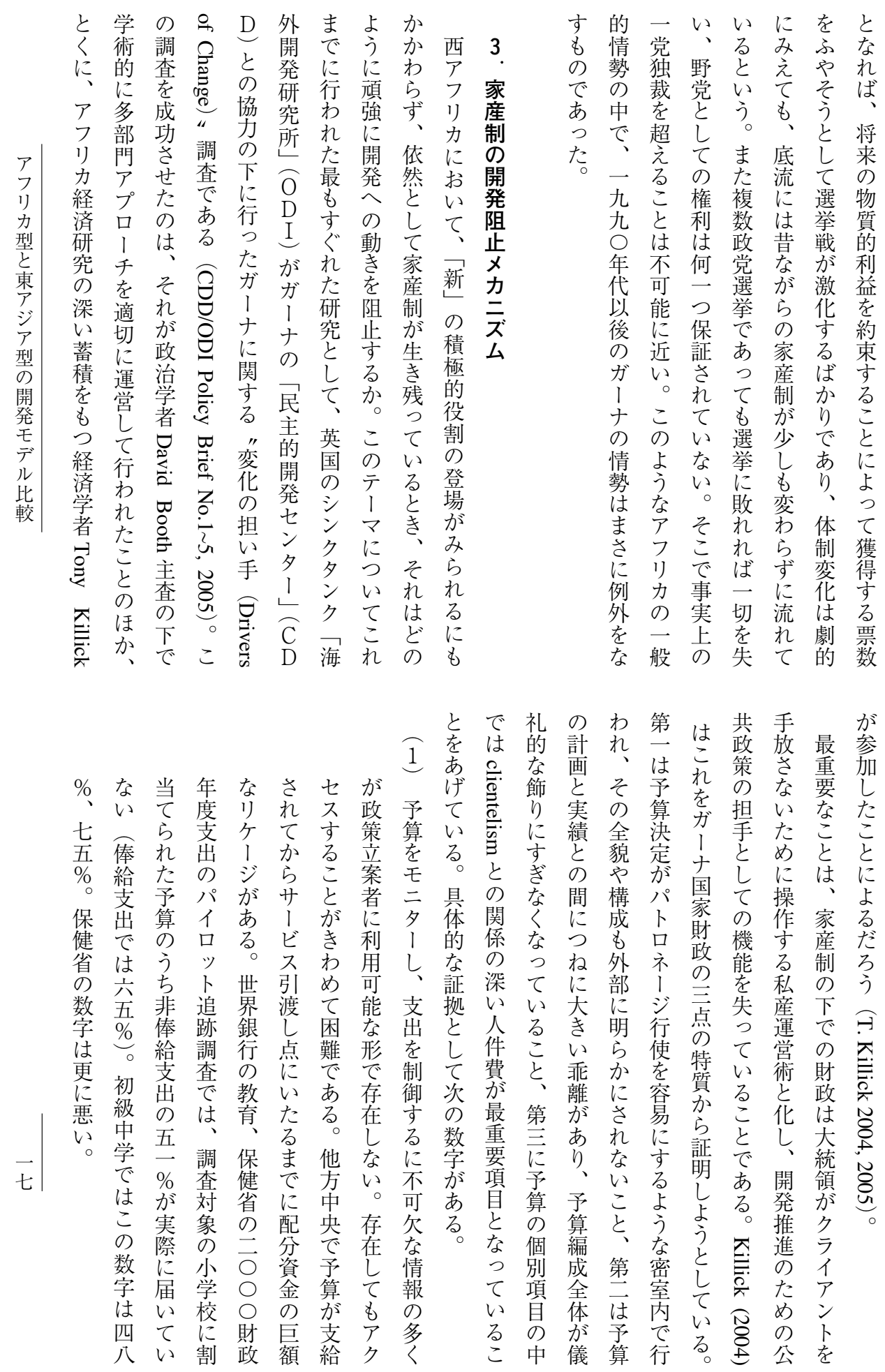
難 因しは

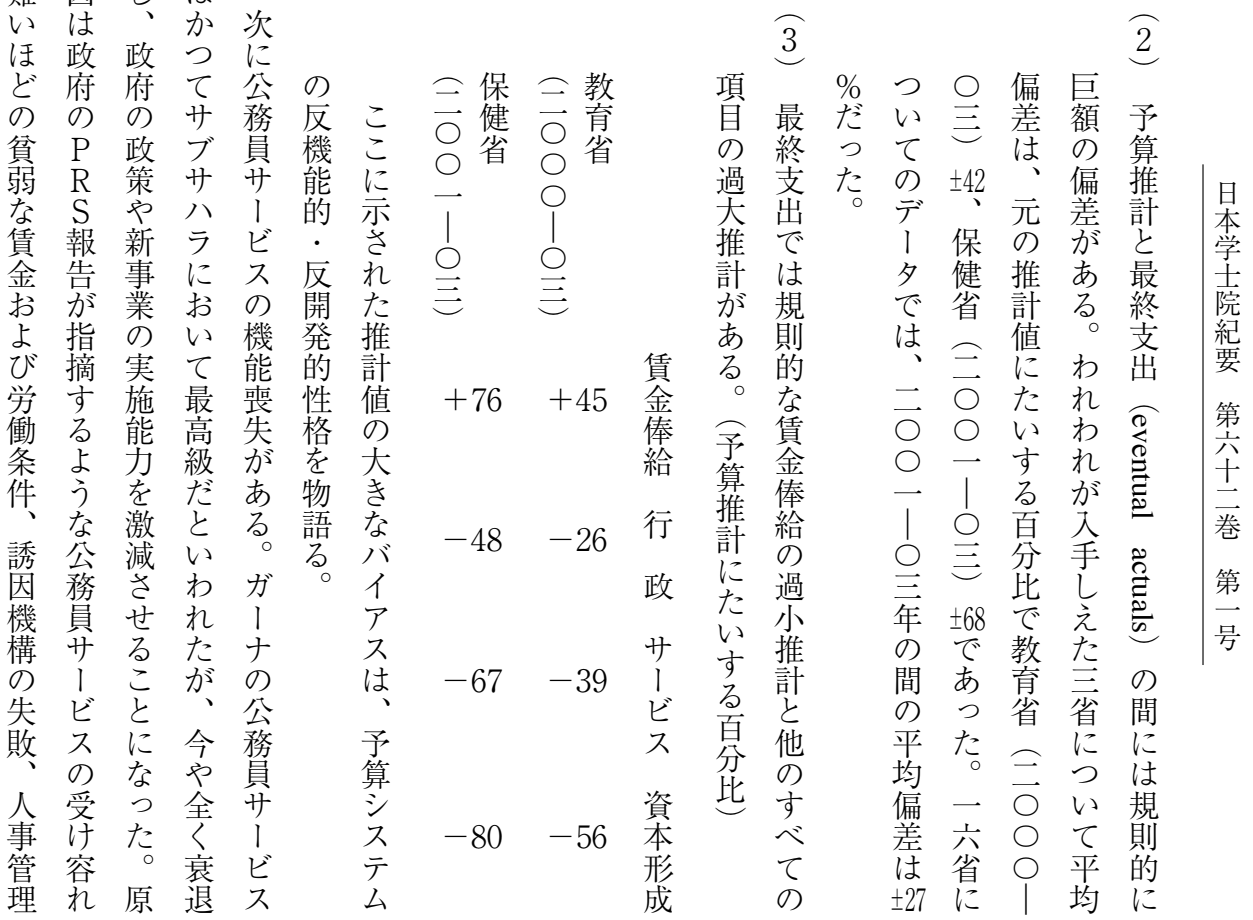
くこ

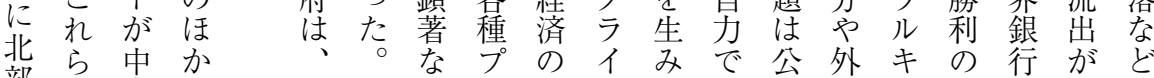
部の央家政表成口発乃出成務域 | 後主あで 総銀産権 1 長フ展ン古功員での逆導つあ

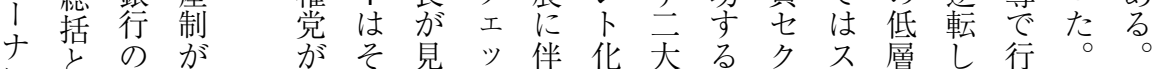
にし発開変れらシうし政民多多部、行たた結

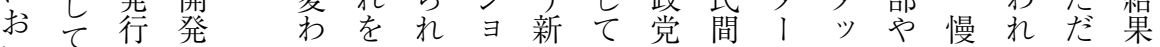
ての権を阻 て 示た た 興い は業手 齿 も い起新のこ $\mathrm{P}$ ○らがに圥削員有 ミのにる 支る。業聞抬の持はないは員減総能

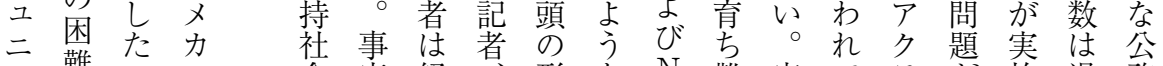
テ難の 会実経者形な $\mathrm{N}$ 難家て 积施過務 イがち ズ階、営教と 環 $\mathrm{D} く$ 産いで戻さ剩員

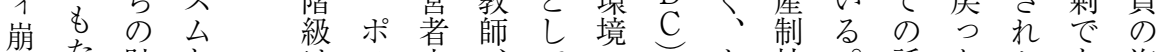

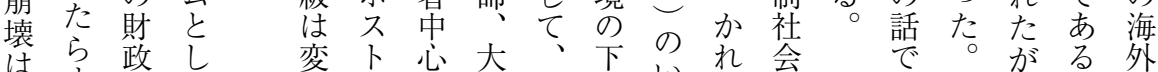
そ古金て 変卜植 の

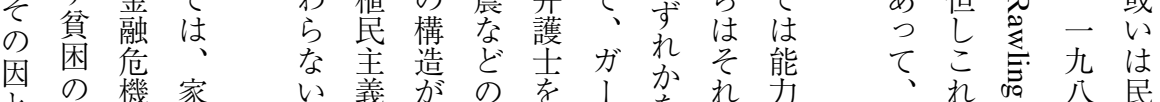

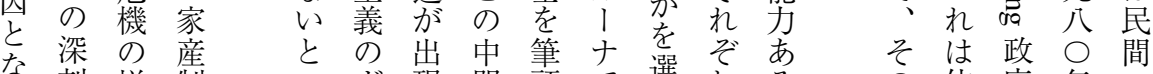

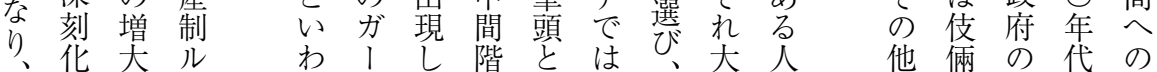


表 1 ガーナ国会議員の出身職業別構成

\begin{tabular}{|l|c|c|c|}
\hline Occupation & $1993-96$ & $1997-2000$ & $2001-04$ \\
\hline \hline Teachers and lecturers & 44 & 32 & 26 \\
\hline Professionals & 21 & 40.5 & $49 *$ \\
\hline Public servants & 18 & 20 & 13 \\
\hline $\begin{array}{l}\text { Entrepreneurs/ } \\
\text { Businesses persons }\end{array}$ & 11 & 5 & 6 \\
\hline Farmers & 5 & 2.5 & 6 \\
\hline Miscellaneous & 1 & 100 & 100 \\
\hline Total & 100 & & \\
\hline
\end{tabular}

*での $49 \%$ のち16\%は弁護士である。

資料：Robin Luckham, "The Middle Classes and their Role in National Development", CDD/ODI Policy Brief No. 3, Nov. 2005

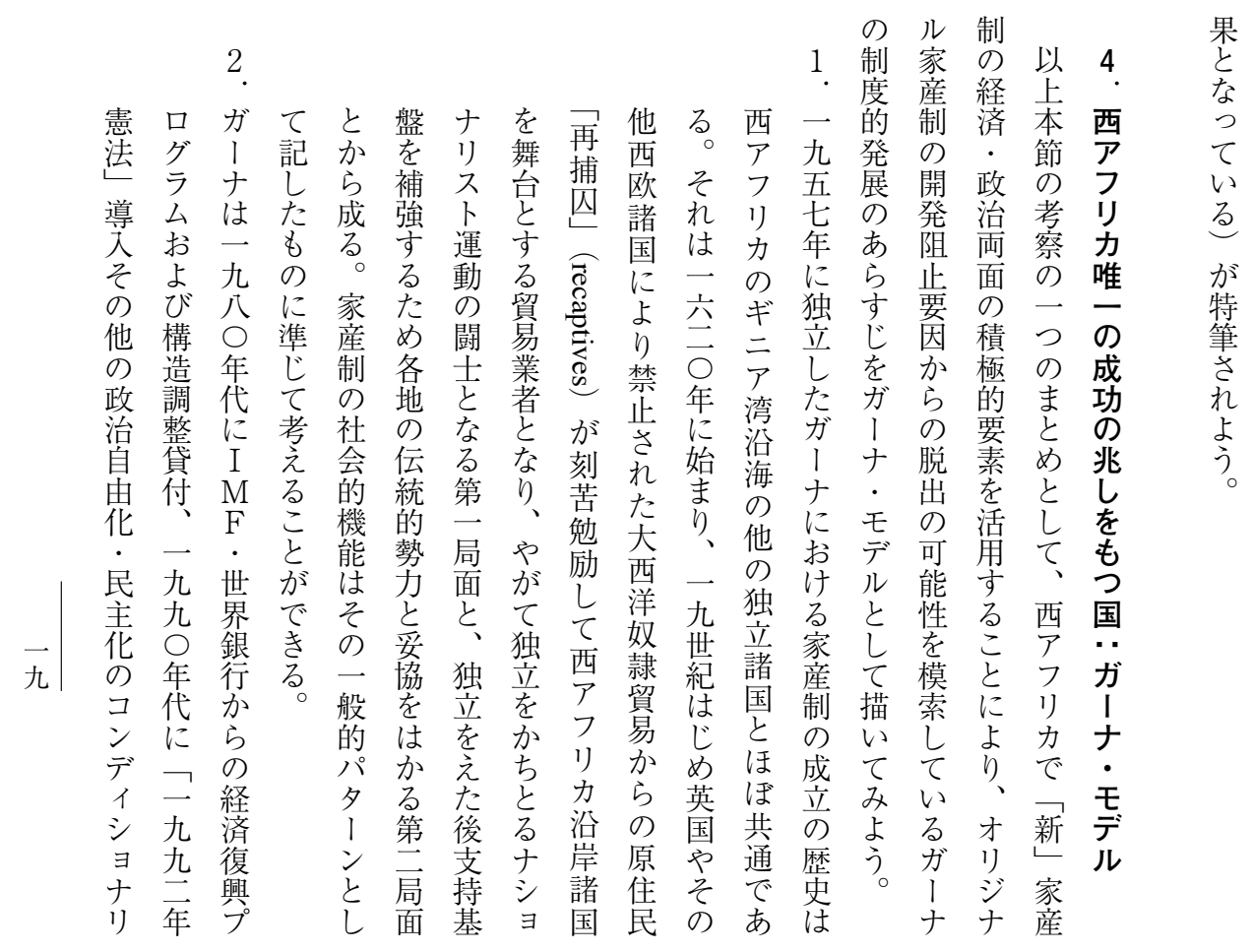



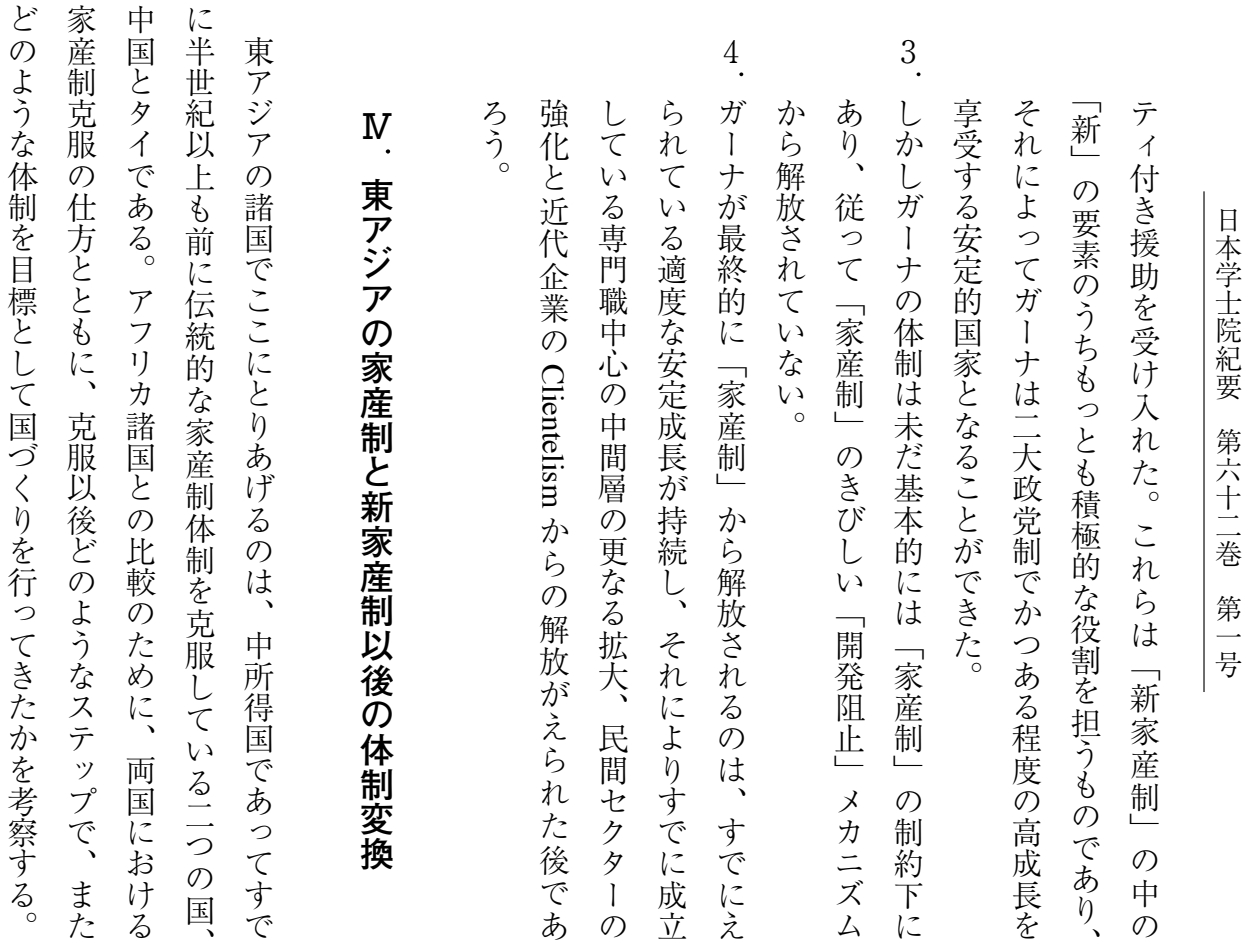

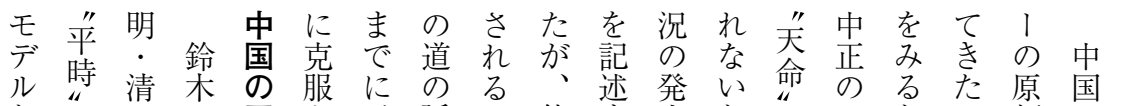

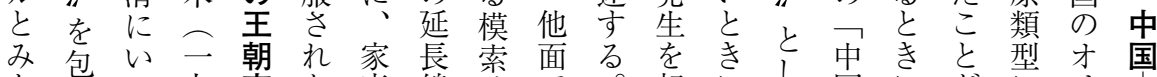
な含た九交た産線時で。起にした国にだ すしる替の制上代はつ点臣義正現ろそ嫁

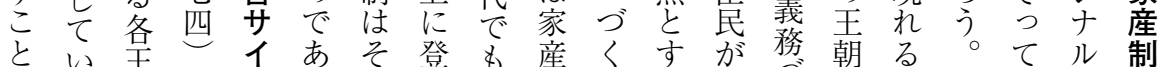

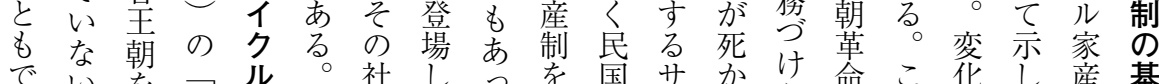

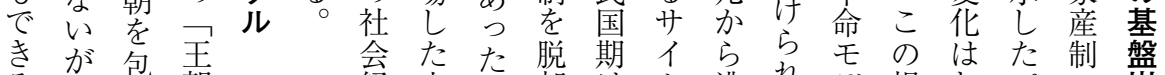
るが包圭朝会 な た 脱期 イ

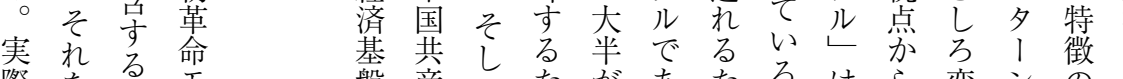
際をる盤産てたたがあたるるらら恋ンのの

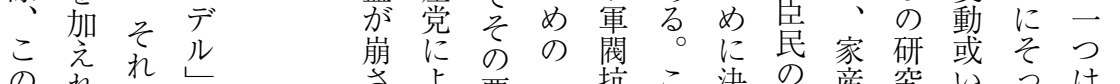
のれ れ 平ばは革は、 さよ要口抗こ決の産究いつは れる素新争の起福制とはて 時王 命 漢 は朝交 革 魏 前替 圭朝荊間晋 のクに占

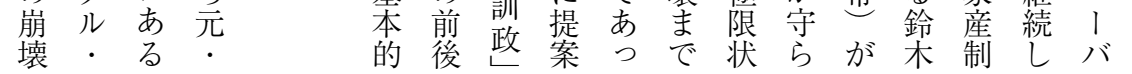
る人系年の モ せ 祉の し 循そ第

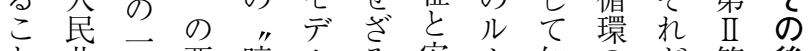
と 共 $っ$ 要 暗ルる安! 知の が節後 に和、素黑はを寧 ラら視古で・ よ国孫㤎時清え の「れ点代ほ中

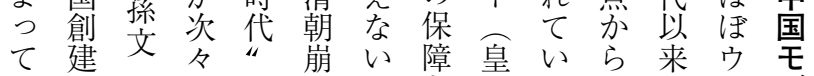
基の訓にで壊極㤎帝る 家継エ デ 
さ破るはは否っ活的則増年が即さ安明生民空苦

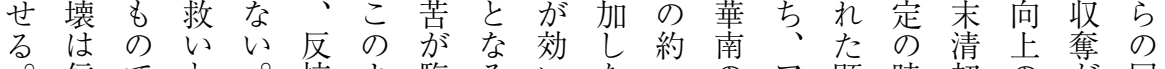

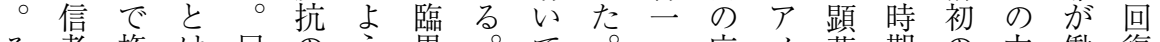
そ者権は民の界。て広又著期の力働復 れを力な衆手にに鈴農し五夲りなが動のい期

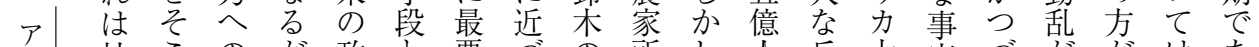

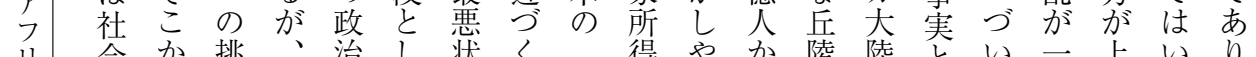

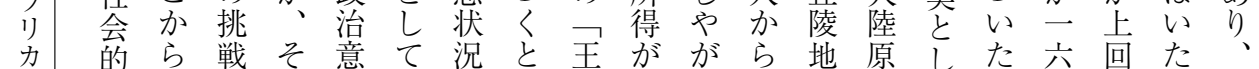

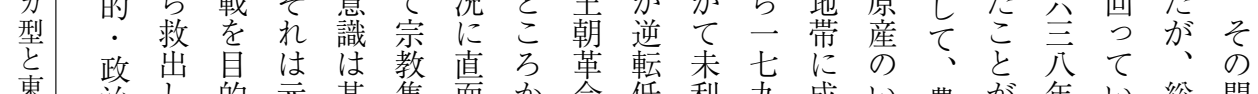
龺 治し 的元 甚 集面か 命低利九成い農 が年い総間

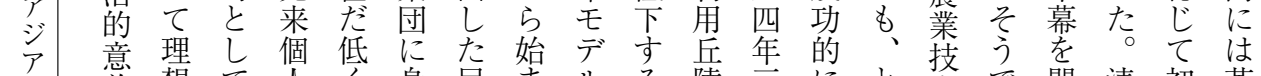
型 義

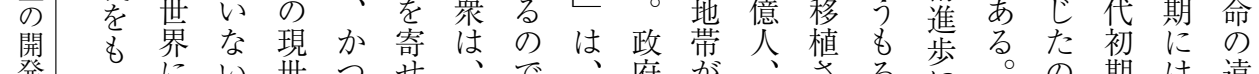

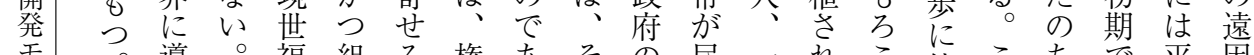

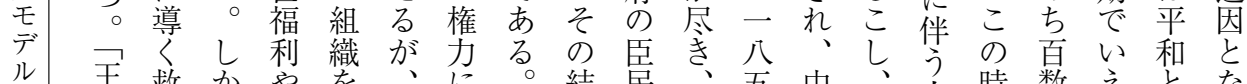
比主救加や在

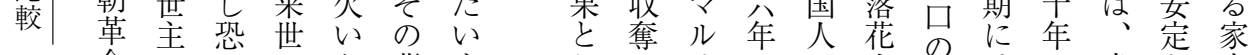

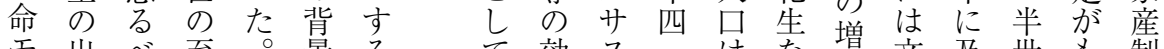
モ出 ベ至。景る て 効 ス・はなな加文及世制

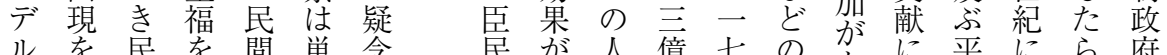

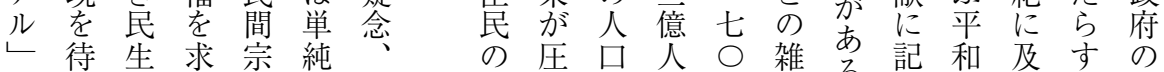

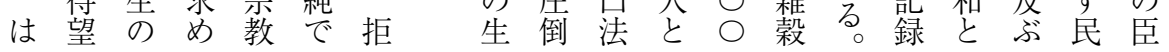

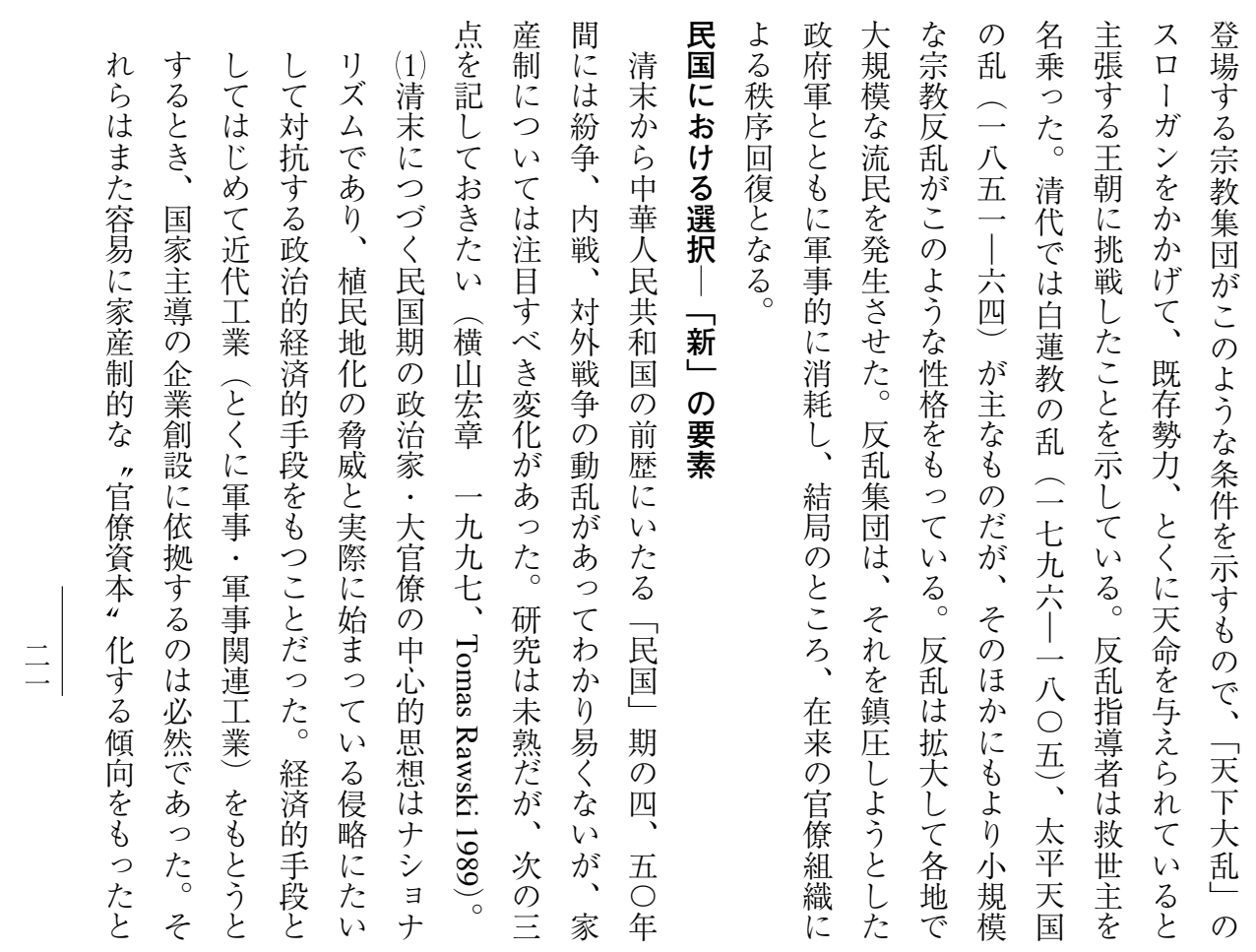


員き貨開し弱的て京軍義復き軍教国もれの思

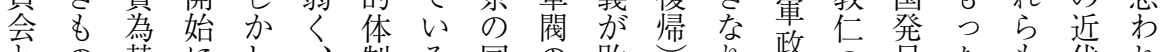
との替にし、制る国の敗市り政の足たも代れ し が・ 方

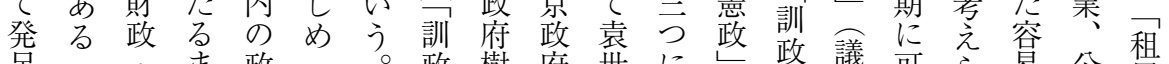

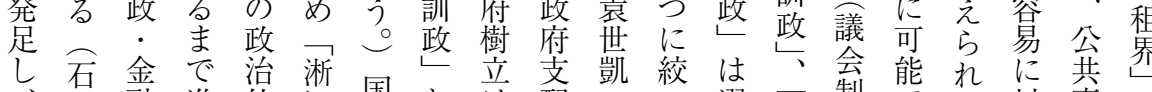

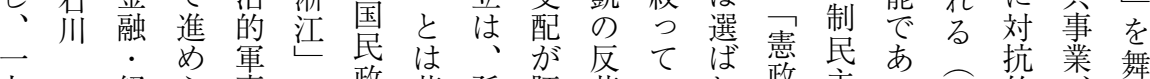

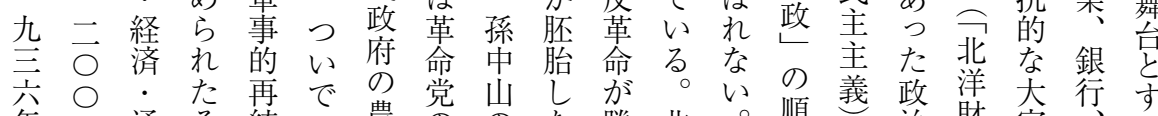

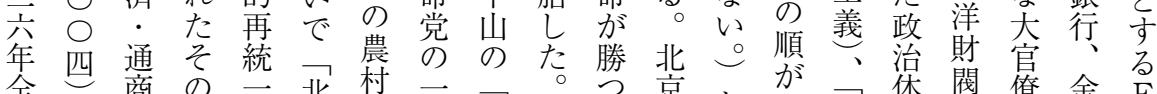

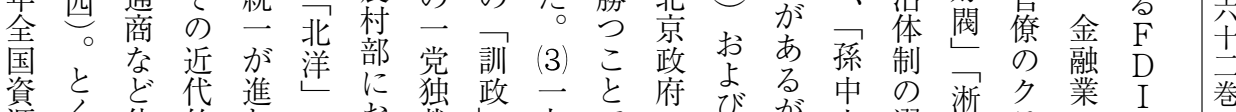

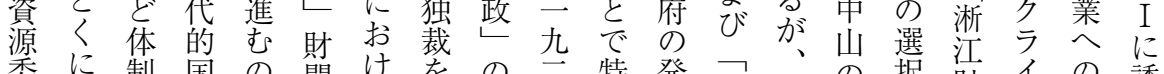
委に 制国の 閥け る

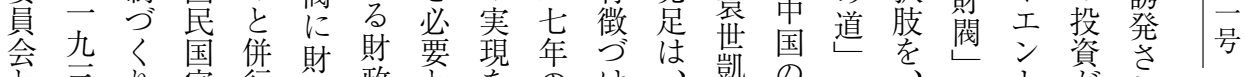
之三り家行 政 政 と基吉

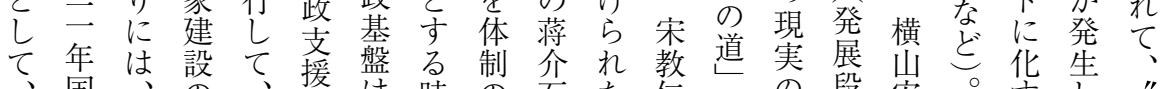
拡防 瞠た 充 設自め 中仰当期の標よこ理制でと章 中傾が族

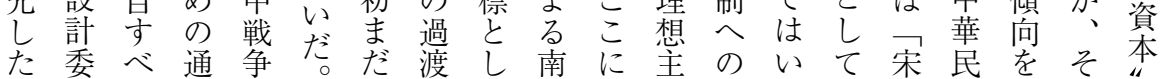

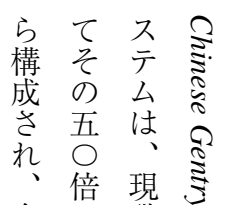

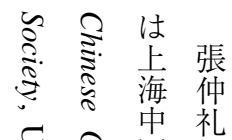

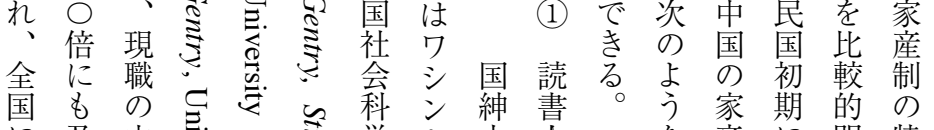

国它

わ方 央 $气$

た 在 政き

行官 野 府

政寮占

おこ地志

びれ 方

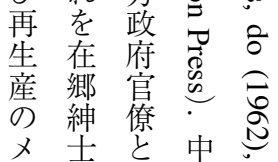

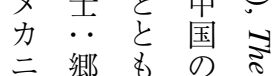

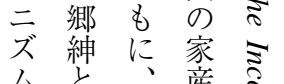

に に 呼 数 制 ミ

よ ぶ
梨ン 紳書

学院 主 的

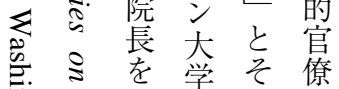

壳 し 時 の

小代得 テ

た た 次 の

ミ气王究全相名経亡 立

ミ志著 体 豆な 済でた

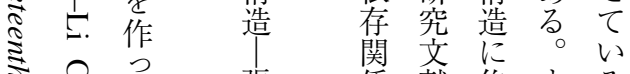

今 張係献焦する

ミ言た 保礼よ点な 社

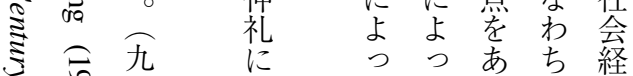

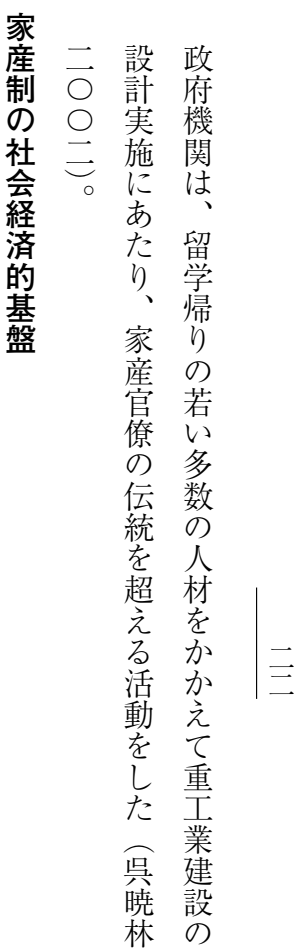




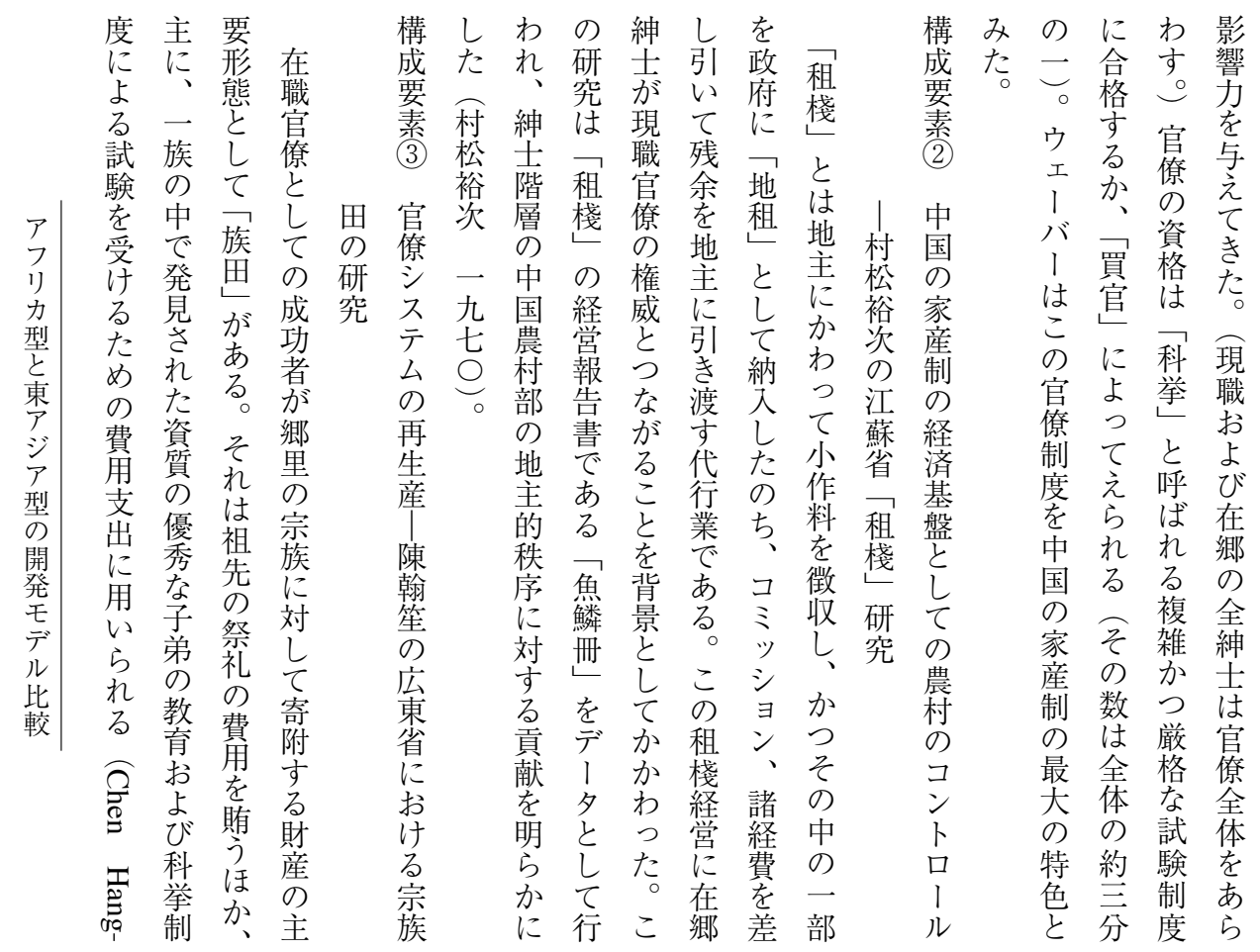

のな゙く制 中 中 民 国 国共家 化 も

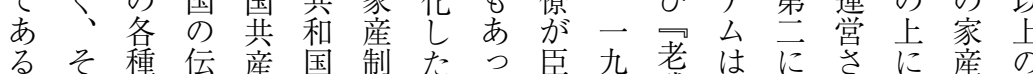

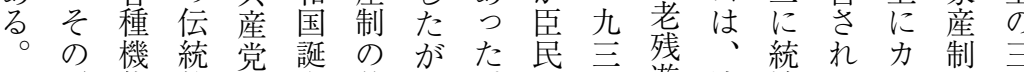
形能的に生鼎、遊清治るリは

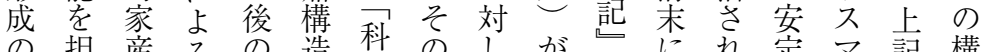

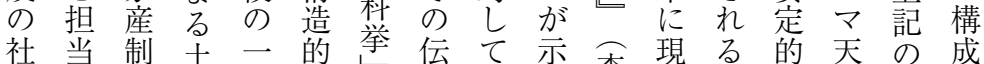

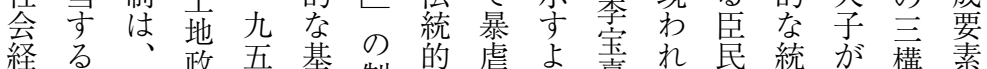
済構後策二盤制家のう嘉たの治文成と

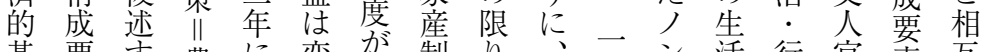

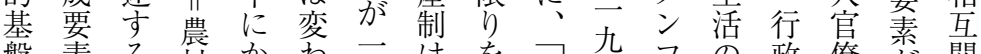

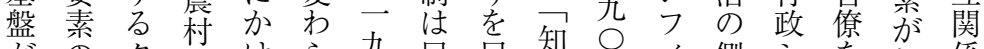

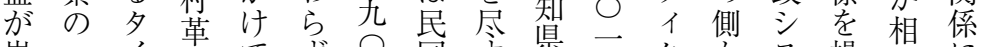

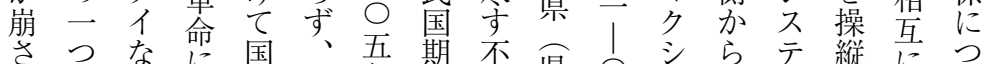

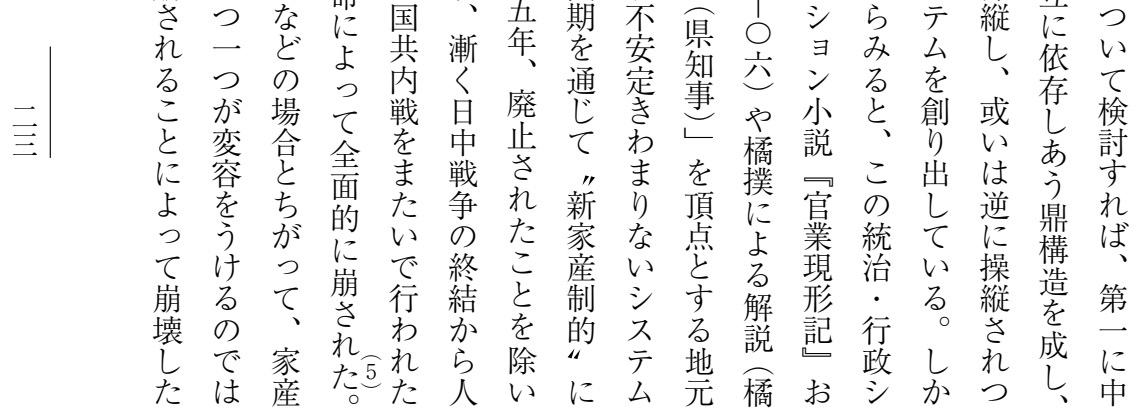




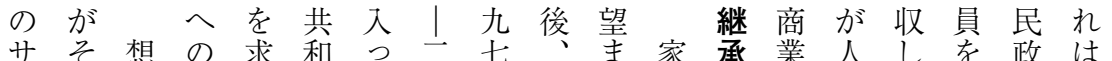

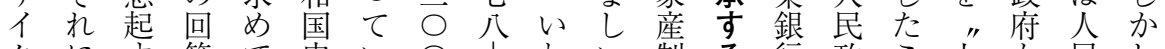
クにす答て史い $\mid$ わい制る行政これか民し ルよべとののる四九ゆだが体の府とがら政中

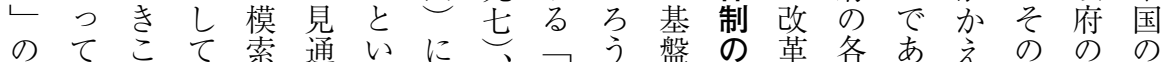

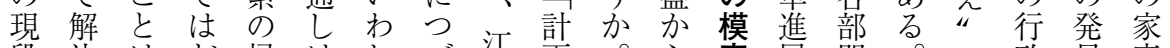
段決はど婦は犯づ江画。ら索展門。政足産 階し、う結、るい泯経中崩と老・そ包・ に制 にな家だ愁人。て民済国壊開妨傘の卞軍あ崩 おけ産ろ あ民己胡生期社し発げ下結来事た壊 い狂制う加政の錦羫乞会た 直なの 面ら も 家当公和五周体 ᄂ な 家地分和依吾周体 突つ崩 制般よ誯法! 知 破た壞 課 の 迫題だ点点れ期のいに市

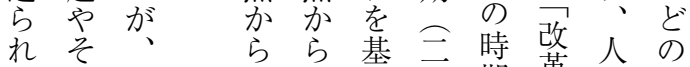

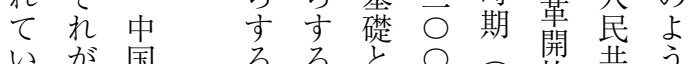
たのの最方四二放和な 課王家の適る|九期国も 題朝産問体人九乞発の 自史制題制民に七二足が

義 る企果沓・つ䌁

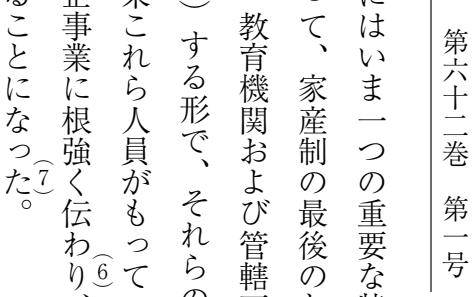
、いの紫と特 国た機国り徵 棠 家 構 棠 で が 企産と企であ 業制と業あり

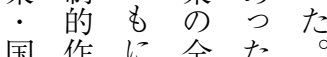
国作に全た。

力向さ が 識得権に近

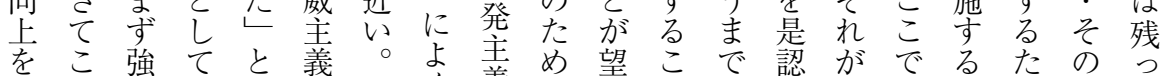

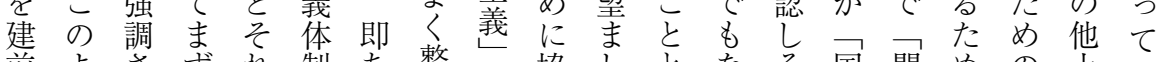
前よささずれ制ち整に協しとなそ国開めの主い

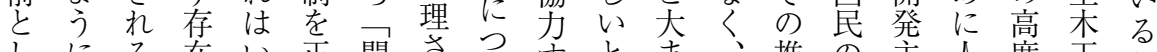

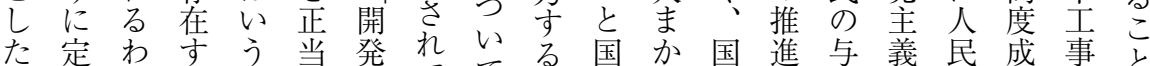
改さ義けてる

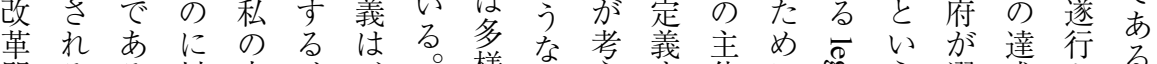

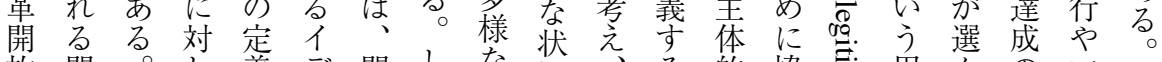

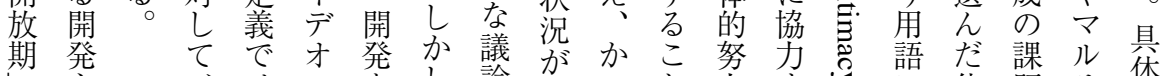

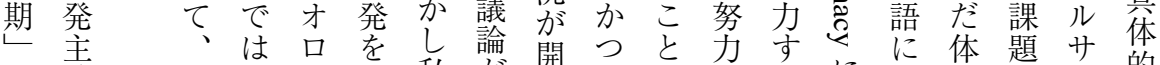

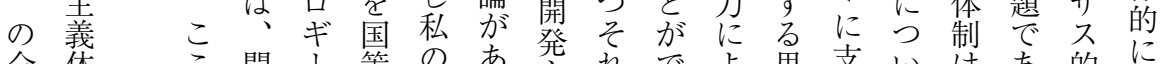
全体こ開策のああ主れ机よ思支いはあ的に

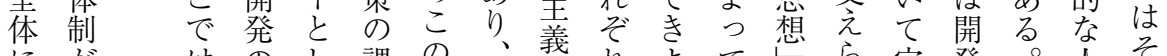

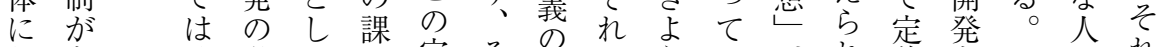
わあ 政必て 題定それ想の主国だれ義主そ至れ たて府 要まと義れ想立がのとてを義し問は酉

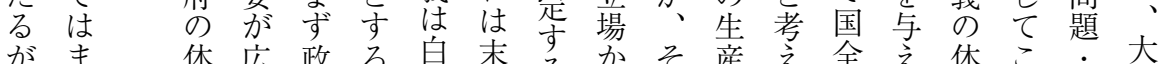
がま 体広政る 帛末 石 る

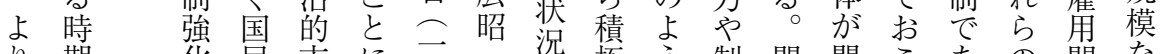

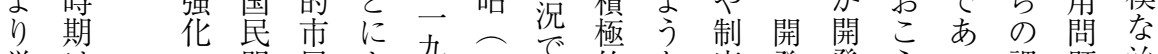

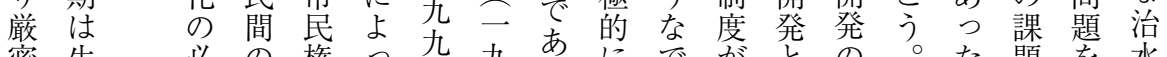

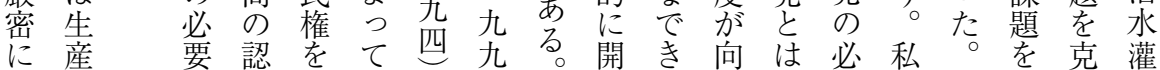


は、ル 年標を ム

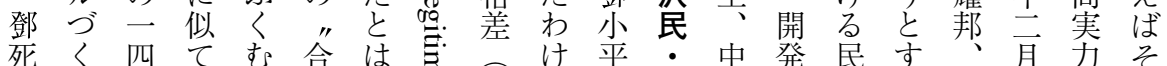

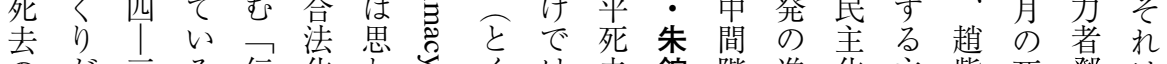

ア 後 行 中 。 統

ア

リ本れ会の配あい方市がち制著併のあいいの党

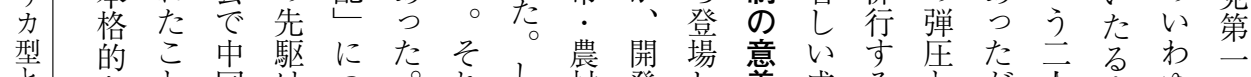

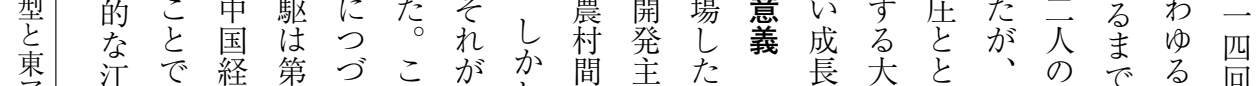

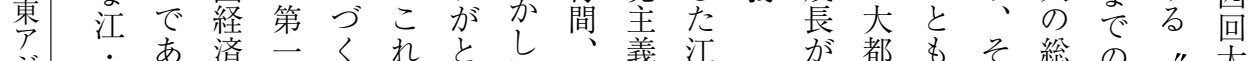

济朱る

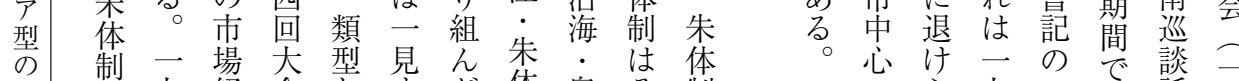

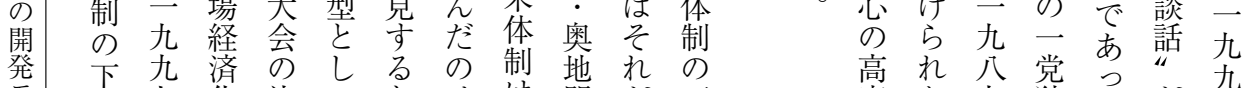

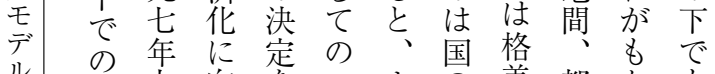

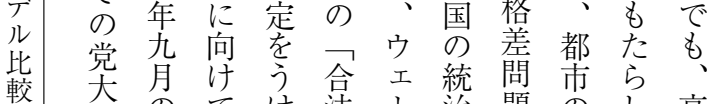
大会のてけ法、治題のし高 会第のて 的バ治に家た度 あ五包、支! 行直計き成

り五括二配が政接 間び長 、大な九の産 ス 依会儿四目制テ組前経わ

高れ八党つ“九 九

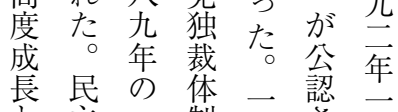

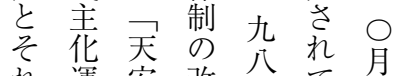

れ運安改 0 茧

に動 開 革 年 の に

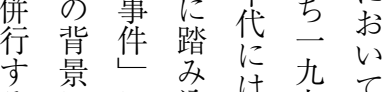

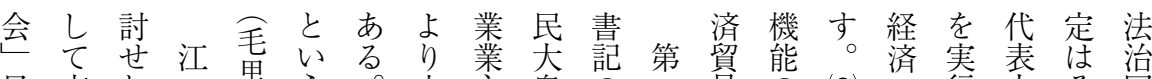
目充ね・里う。中主衆の一易の (2) の行大そ国 標 分ば朱—統そ国の の”六委三政管方 会こ

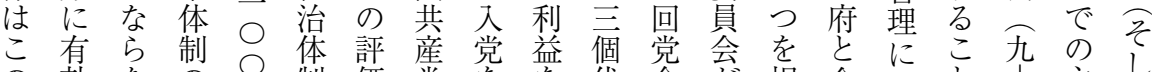

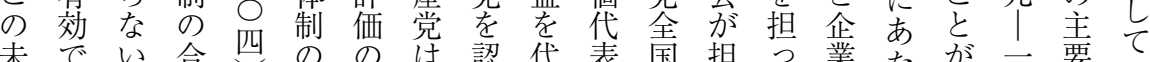
未でい 合解な の 決かし化訂否級る 卞“会当い分る。めの果而 問つか改のは政こるでこ事た離国ら審でこ 題たし、革必別党と要文事が業家れ議あ あ

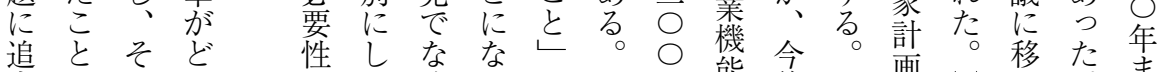

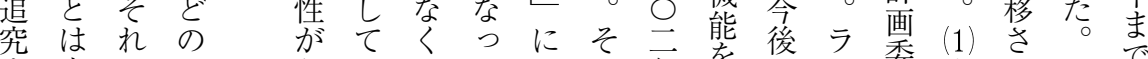
す事がよ認、、た拈の年を佼、委中机こで

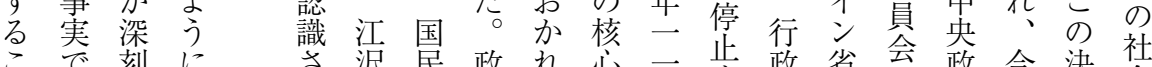

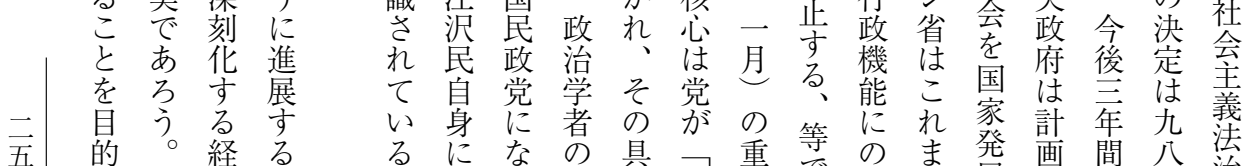
的経るになの具口重等の年発画間八法

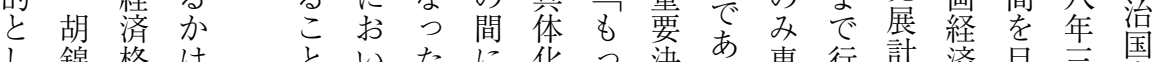
こ 錦格は は と い た

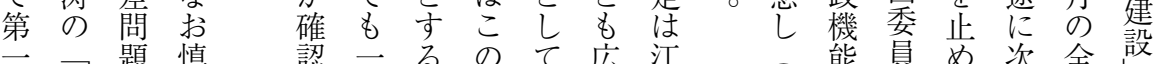
六和に題慎学評決私沉沢 国態会、次全し

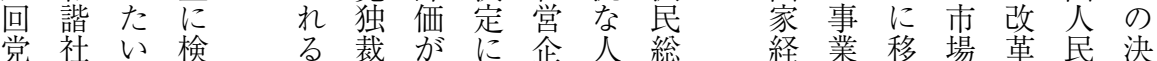


3

2

1.

経つ成産ば行民がけ断後のそ生ごた

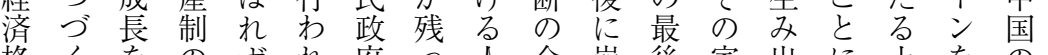

格くをのず机府つ人全崩後家出に土をの

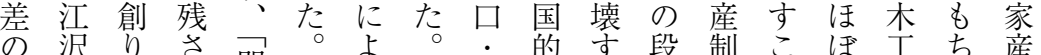

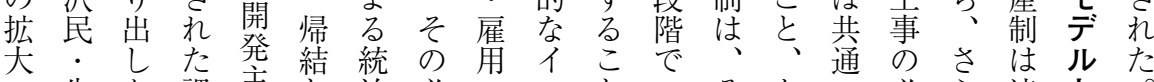

の朱た課主と治必のンとのそなの必ら清と

た鎔。題義しの要危フに中れど盛要に代

め基ををてた性機ラよ国をの衰を大に

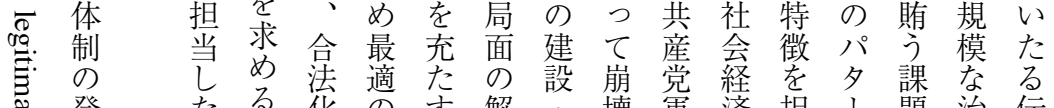

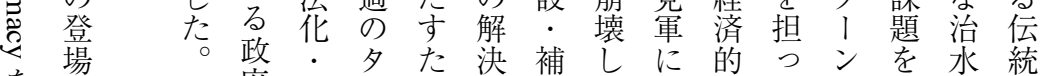

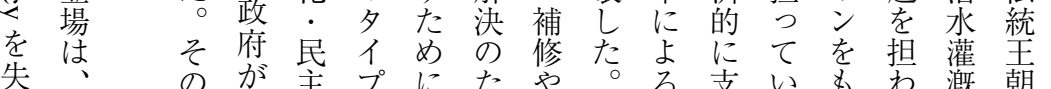

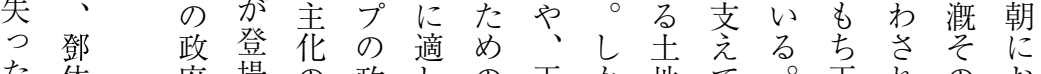

た体府場の政しの王少地てる。主れの的

こ制はし貝権た高朝し改い朝た他い

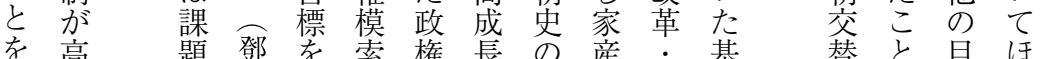

を高題鄧を索権長の産: 基替と目ほ

背度に小ものの維サ制農盤のの、的ほ

景成 応平つ一模持イ怔村等

と長光体政環索のク支䩗国政通

しに、制権とは必儿主命共々各域の

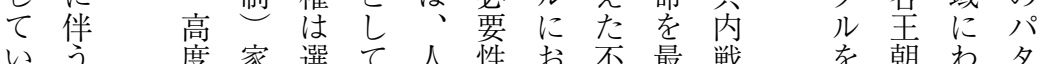

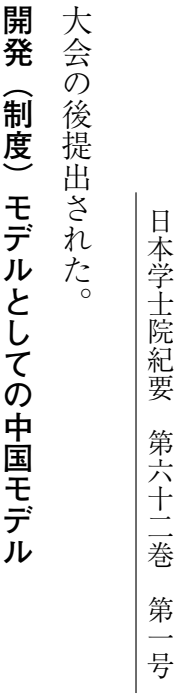

民強教よそチ

地制䇤

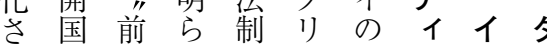

れを世沓的 家 ナ

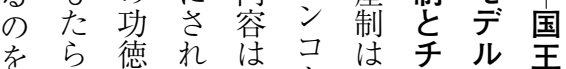

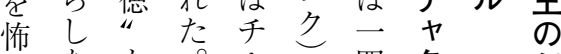

れたか。ヤ王四ク創

た対 ら

マボての主に紀革

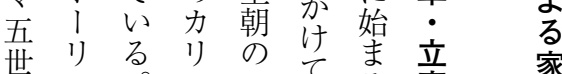

世

八条ず性シ サ ユ 君制

六約れはスグ㔈改

八二に儒公全主

一八よの律体朝

九六こ”顧 制 か

兀五の 天問製ら

○の制命に袋公

即を多な゙

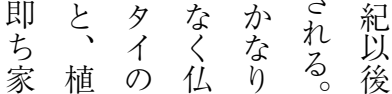

2

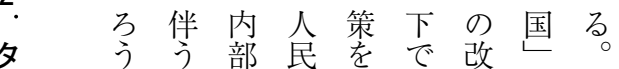

学吕政必、革の江

生 ら府要格に実。

中政下主差つ現朱

間策でる題 が 巨制

層ののにはる 歩は

の動 政い更成を

更き治たに績踏そ

るり自た大微出自

増も㤙。少し体

と開: 胡も方場

行発民錦の、経

動や主涛でさ 済

に教化政あら化

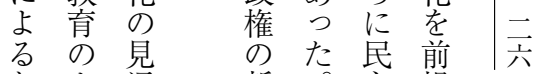

と通新。主提

ろりさは他政亭

が層、格でにる

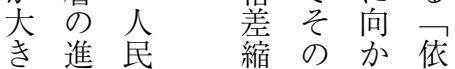

展政少体つ法 


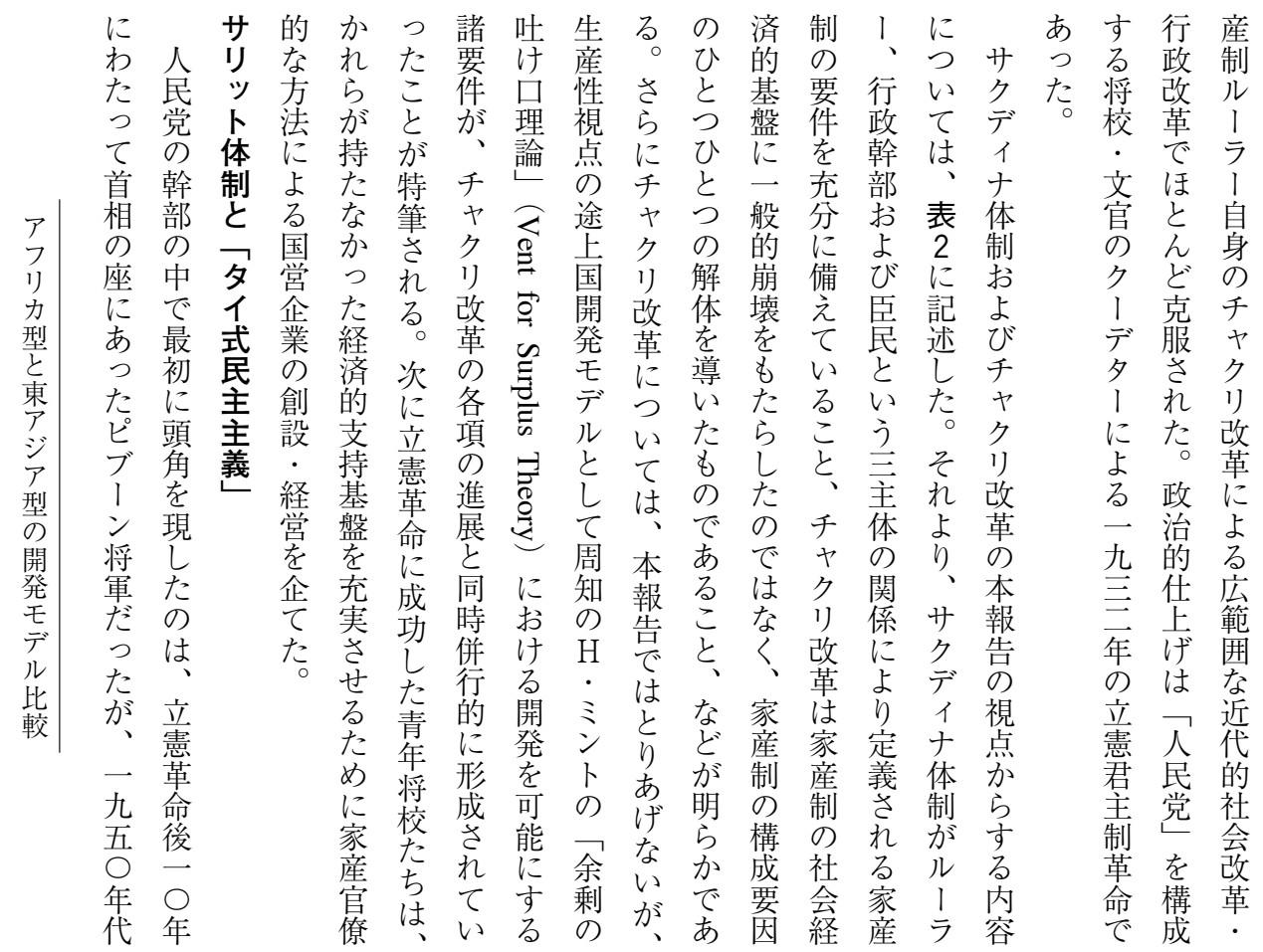

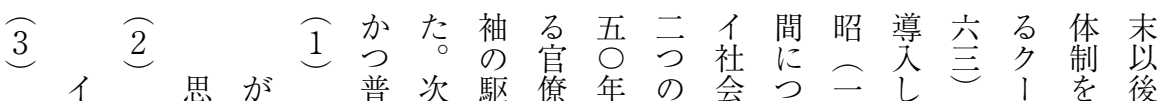

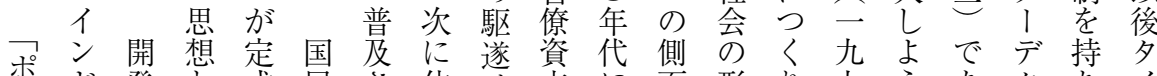

ホド発と武民さ体は本に面形り九市あ多ち

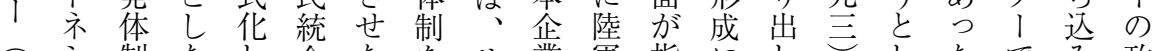

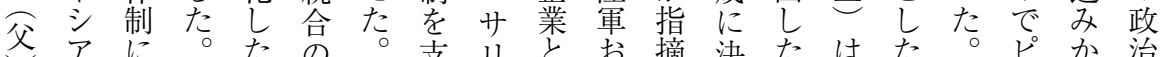

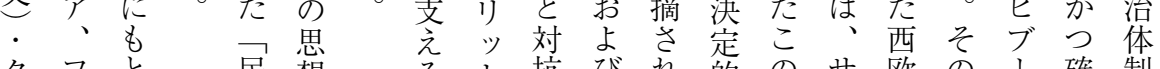

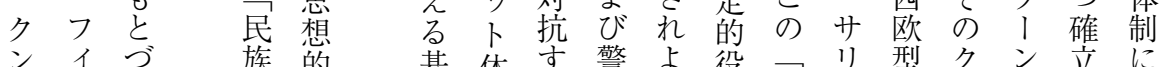
ンイづ族的基体守警よ役っリ型クン立に

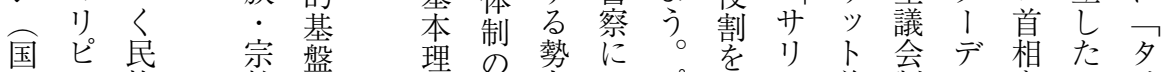

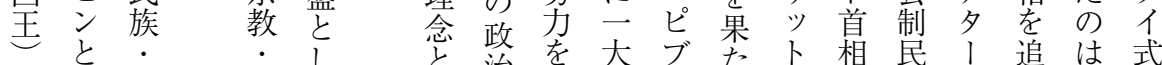
の同国国て造基擁派、し体が主は放、式

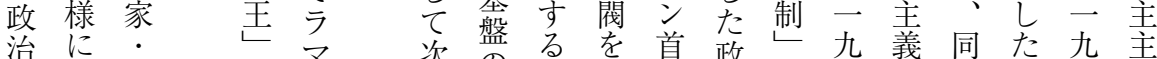

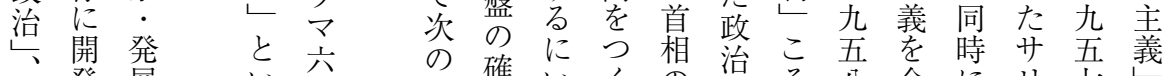

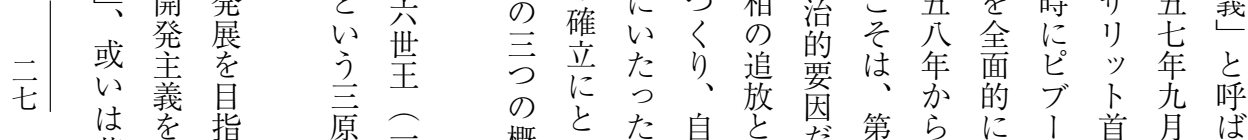
原一概とた自と第らにに息月ば 命揱賏九 念て

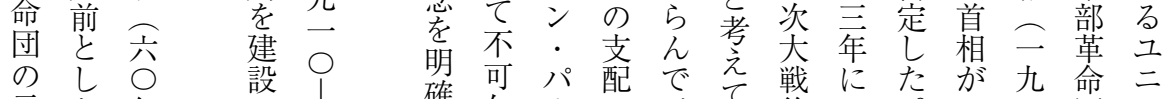

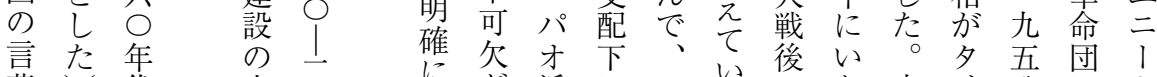

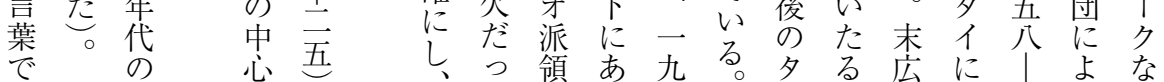




\section{表 2 タイの家産制一サクディナ体制のノート}

1. 1932年立憲革命にいたるサクディナ（Sakdine）体制

サクディナ体制というのは，アユタヤ朝（1376-1767）のトライローカナート王の治世（1455）に 法制化されて，バンコクのチャクリ（ラタナコーシン）朝（1782-）の 8 世王朝の1932年立憲革命に いたるまでつづくタイの統治体制をいう。これは1924-1940年の間夕イ政府の法律顧問であったフラ ンス人 Robert Lingat やチュラロンコルン大学経済学部教授 Chathip Nartsupha らによって研究され, 日本には当時アジア経済研究所の研究者であった野中耕一および末広昭の両氏によって詳しく紹介さ れた。チャティプ・ナートスバー著, 野中・末広編訳『夕イ村落経済史』井村文化事業社, 1987。

この統治体制は全国土の唯一の所有者である国王の専制の下に, 行政幹部としての官僚層がいて少 なくとも名目上，官位に応じて土地を分配された（ランガによればこの分配された土地の広さをサク ディナという)。臣民は自給的かつ強固な長老制の共同体に居住しており，土地を占有するかわりに， 納税・賦役の義務を負っている。諸侯は存在しない。これは本報告にいう「家産制」の一般的特徵を そなえている。後に参照する文献にも Patrimonial の用語はしばしば登場する。次に野中・末広編訳 により, サクディナ体制の要点を記録する。

（1）国王と国土 アユタヤ時代初期の土地制度に 3 大原則があった。(1)国王が唯一の土地所有者で ある。(2)国民の土地売買は禁じられる。(3)国民の土地にたいする権利は弱い。(1)の所有制が実 質的なものであることは，首長が国民の間で土地を割り替する慣習があったことによる。しか しこの慣習はその後なくなり，徵税・賦役の根拠となるのみであった。(2)の土地売買の禁止も 遊休荒廃地に関しては残ったが, 田畑についてはバンコクのチャクリ（ラタナコーシン）朝で は行われなくなった。(3)は国民が土地を占有するだけで耕作しないときに権利を失うことであ った。その後, 所有と占有とは切り離された。

（2）王室財政 アユタヤ時代から皇庫局の重要な収入は土地税（田賦）であった。土地税ははじめ 田の収穫に対して徵収され, 後, 所有者の排他的保有面積, 或いは耕作面積に応じて徴収され た。牛耕田・天水田に対する土地税はバンコク時代までつづいた。このほかに徭役があり, 国 家に貢納する米を生産した。その期間はアユタヤ時代年間 6 カ月, バンコク時代 4 カ月, つづ きその後 3 カ月に縮められた。

（3）文官・武官は官爵，官職の地位に応じて一定面積の水田が下賜された。但し実際に土地を下賜 されたかどうか, 単なる官位を示寸手段ではないかという議論がある。ランガは後者の説である。

（4）臣民の居售するむ只同体は内部で強固に結合されており，国家とは元来対立関係にあった。 労働力の徭役制度にそれがはっきり表面化した。村の自治は長老会議がとりしきり, 家族・男 女・生活・若者間の争いごとを調停した。タイ社会に奴隷がいたが, それは債務奴隷, 戦争奴 隷などで, 数は少なく家族の一員として扱われた。

2. ラマ五世のチャクリ改革

チャクリ朝のラマ 5 世（チュラロンコーン帝；1868-1910）は明治天皇に比べられる英明君主だっ たとされる。かれは1865年英国に迫られて調印したボーリング（Bowring）条約の結果として，タイ が近隣国のように植民地化されるのを惧れて一連の近代化改革を行った。Chayan and Ukrist (1987) は，そのうち “4 大改革”とみなすものをあげている。(1)対内的に自らの「絶対権力」を確立する措 置として従来朝貢 州として半自治的に振舞っていた北部夕イ，東北夕イおよび南部夕イを併合した。 (2)大行政改革 中央政府の在来の 4 省 (krom) を近代的な官僚システムに刷新した。もっとも重要 な機能一領土保全，国防，外務，財政，交通，教育訓練および司法は新設省に改組された。まず内務 省が改組され，それが産婆役となって新省が設けられた。各省は全国の地方部に行政を伸長させ，各 地の “支配的貴族”を俸給を受ける官吏で置きかえた。行政改革は国王および皇室によって支配され る強力な官僚国家をつくり上げた。内務省を中心とする行政機構は地方各省から余剩（租税, 森林租 借，鉱山採掘料）を吸引する尖兵となった。ラマ5世はこの改革にさいして英国のビルマ・マレイ植 民地行政を手本としたといわれる。(3)教育制度改革。但しこれは王族貴族掞よび高官の子弟の官僚と しての養成を目的とするエリート教育であり，庶民を閉め出すために高い授業料をとった。(4)国民徴 兵制（1888年軍隊法, 1905年改正）の実施。

他方，ランガやチャティプはラマ 5 世の改革の内実として, 土地売買の自由化（1901年）の地図つ き地券交付, トレンス式登記法採用, 奴隷解放 (1974年開始), 納税, 徭役の金納制導入 (1901年徭 役代法など）等による生産要素, 生産物市場の開放措置を重視している。実際，チャオプラヤ河デル 夕の未墾地はボーリング条約締結後間もなくして, 英国の商社が運び増大する米輸出需要に答えて開 拓を開始した。デルタの各地に縦横の運河が開削された。それはこの “供水適応農法”によるデル夕 で水を地域全体に平均的に行きわたらせ，また人と資材と収穫米を運ぶために不可欠だった。そのた めの資本は王室・王族から出た。解放奴隷をふくむ農民の大移動がこれらにより可能となった。それ から第 1 次大戦にいたるまで, デル夕人口, 作付面積および米輸出額のいずれも年率 $3 \%$ に及ぶ成長 がつづいた。このような変化の背景にすべてチャクリ改革の制度近代化があった。 


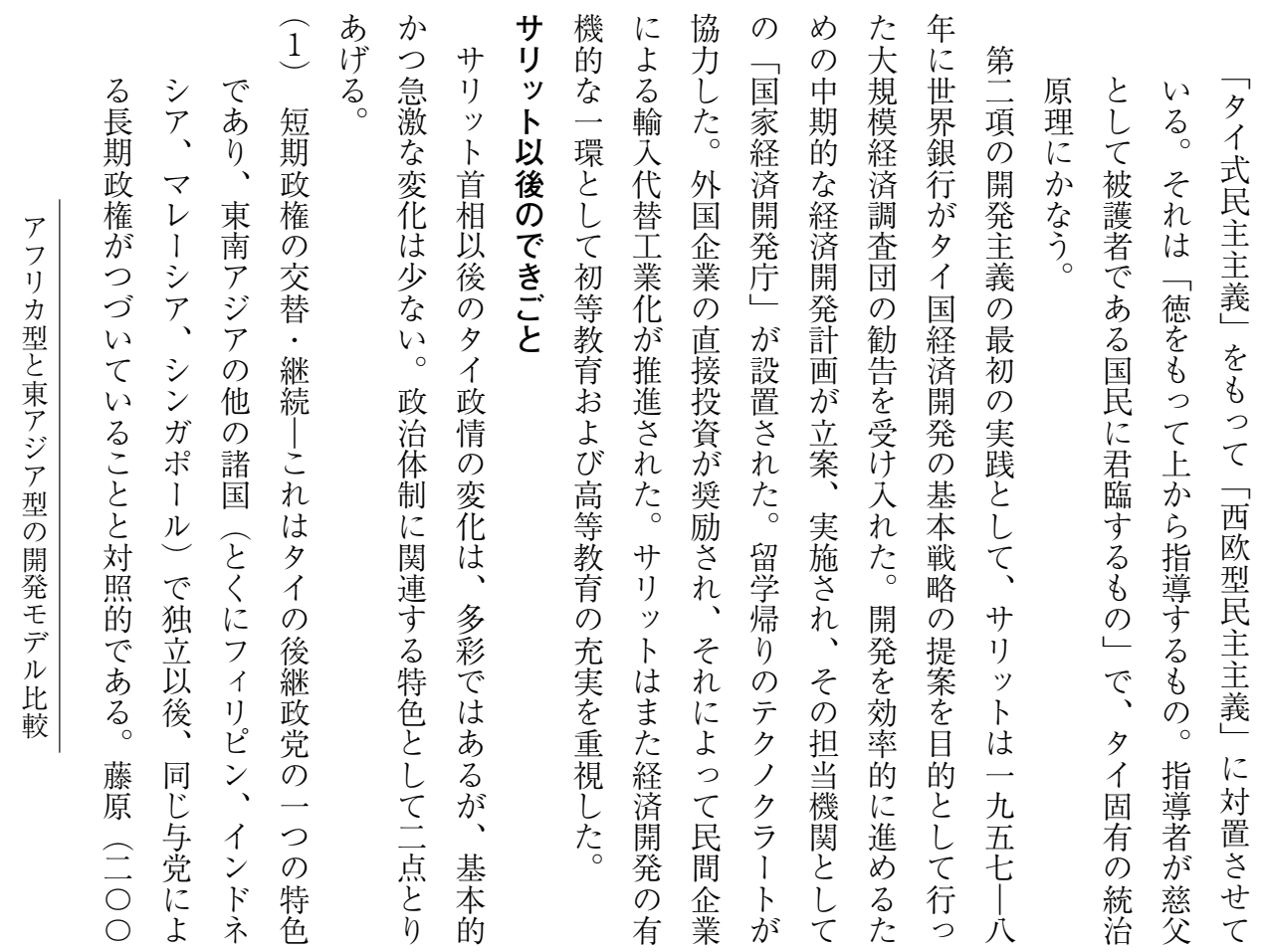

2

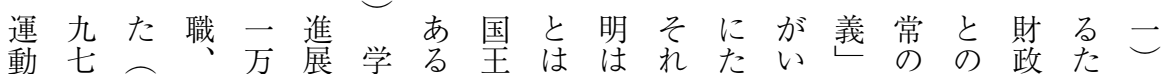

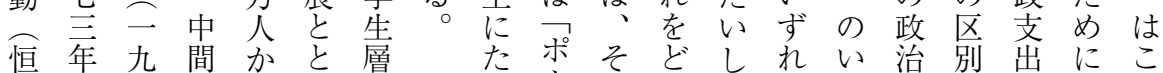

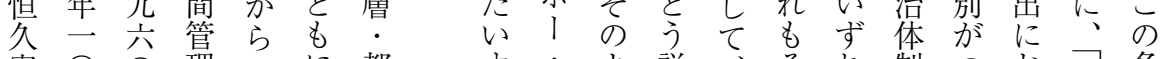
憲 ○○理二に都市方説、それ制つ拈政多

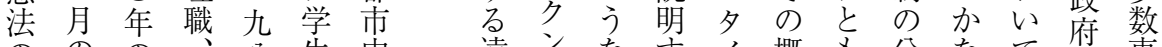

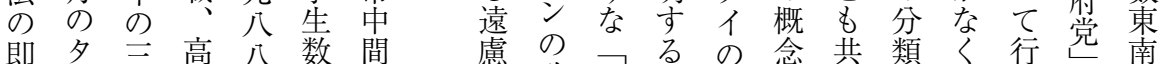

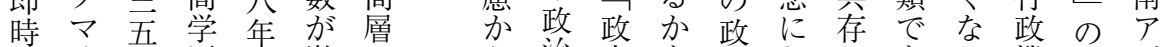
制 サ方歴六激の治府を党おしある機概 シ 定卜人の公増拡採に党課政けてるた構念占

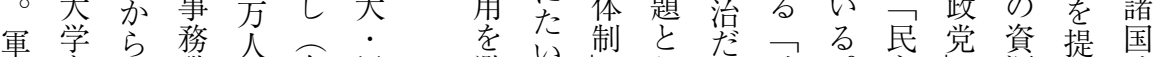

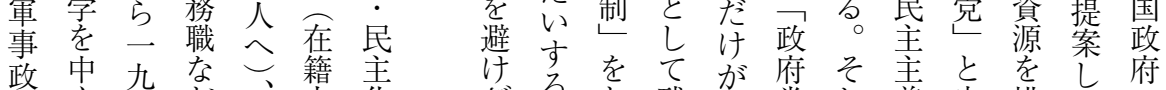

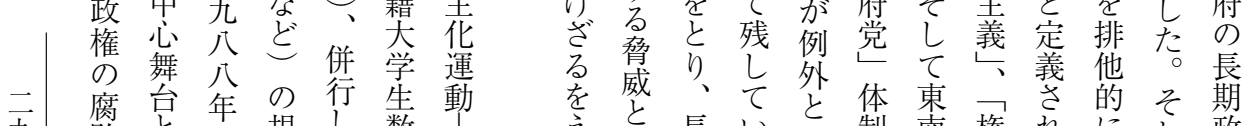

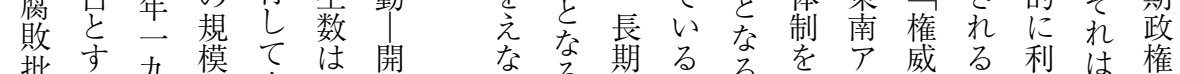
批す九模ては開なる期るるるを威る利は権

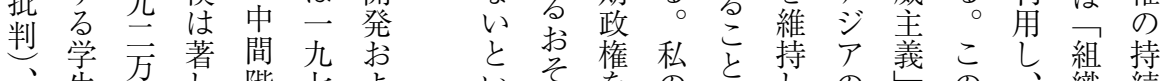

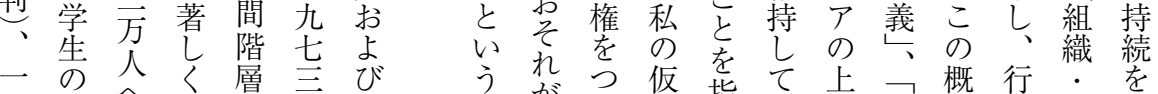
九反气拡居教年胎く説指い記全念政之説

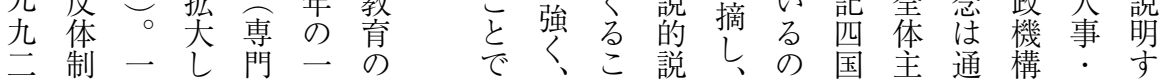




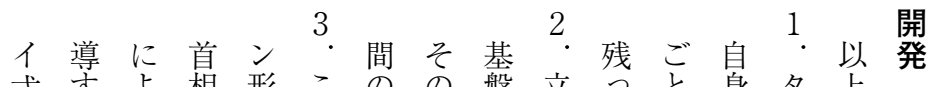
式す よ

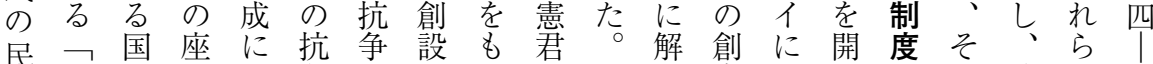

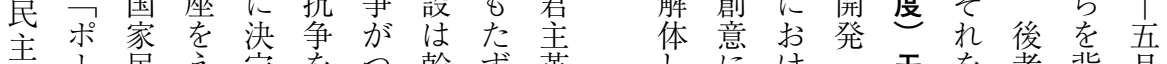
主 義公族 た 的結づ部目命役着く の な どク (2) 卜演、的業九 展

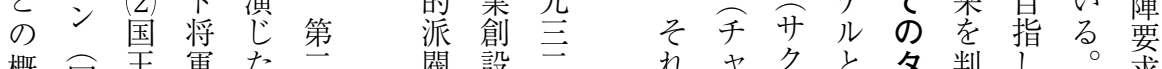

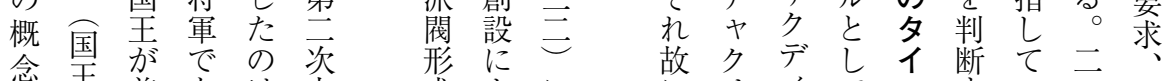

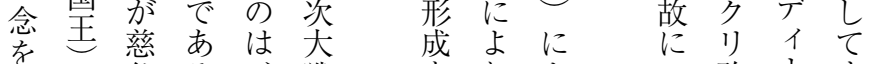

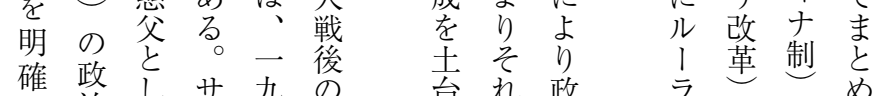

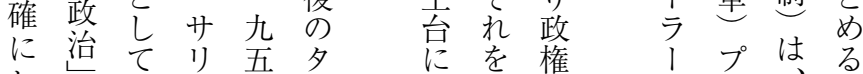

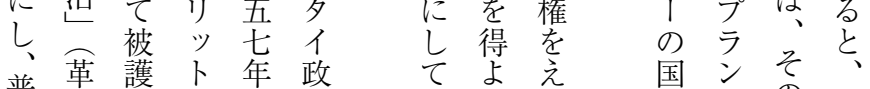
及普命首軍治 行方た

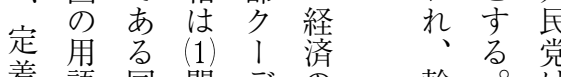
着語国開デの の 幹。け さ年民発夕パ 部し名威成国あ

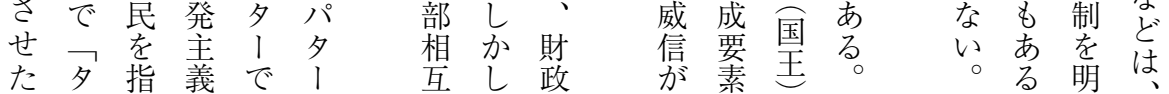

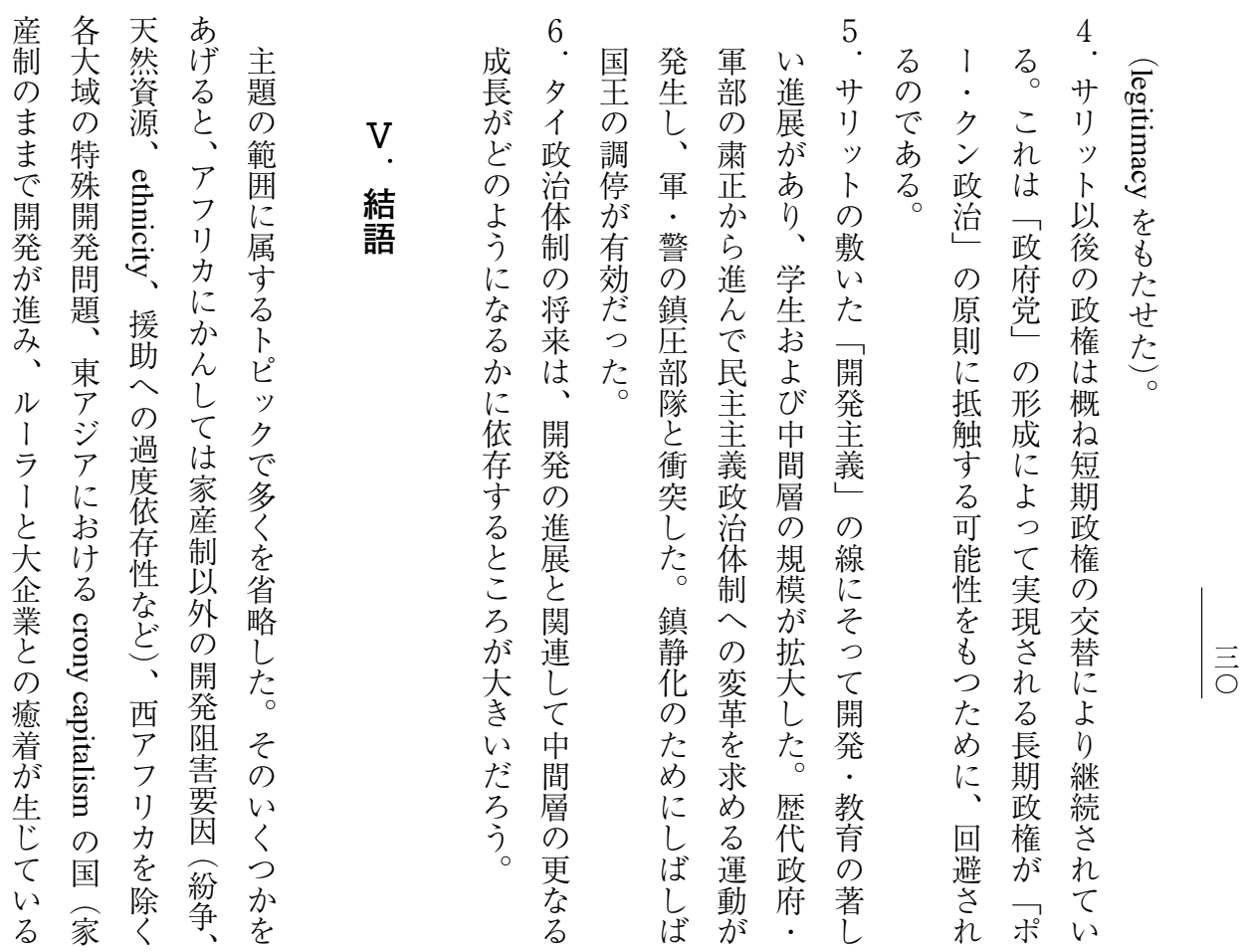



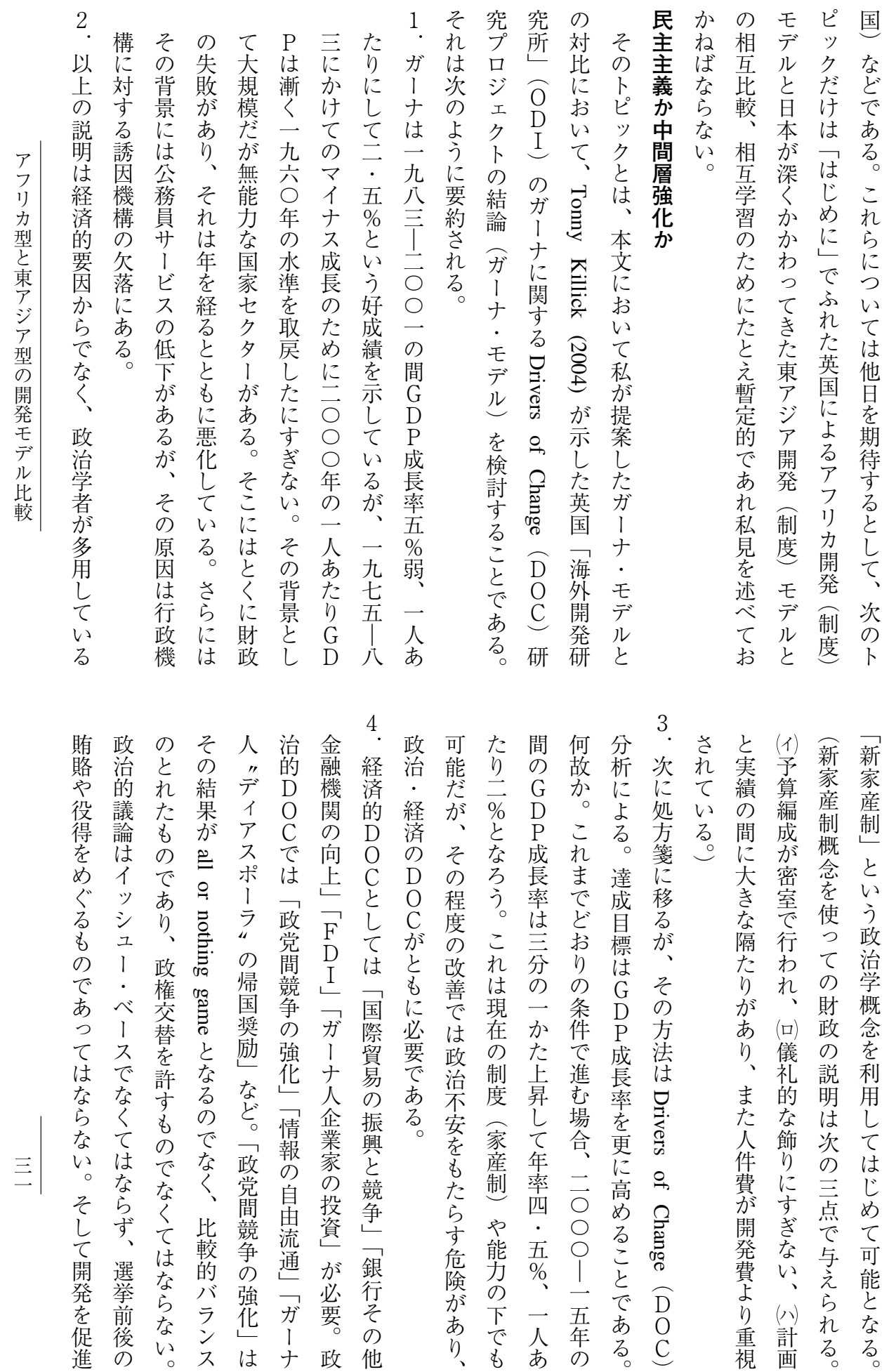


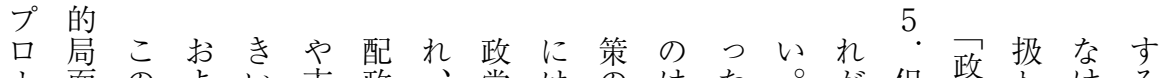

面の よ

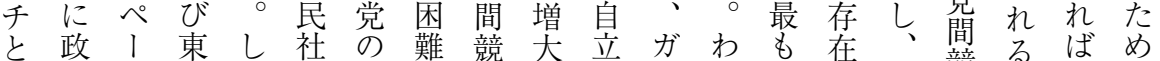

同治パ南加会地な争し性、机成守民競るなな

ご学、

あ概 経アのの相問 し だ效経がない義強即い済

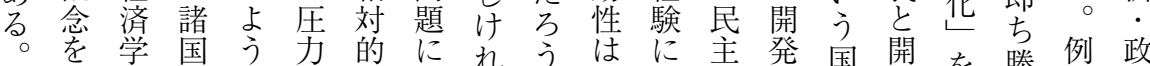

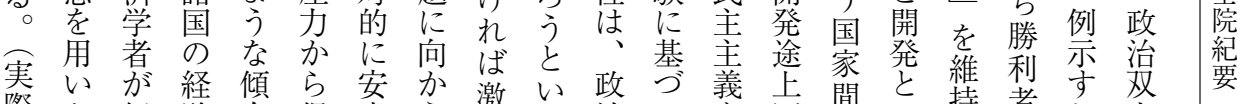

際た経験向保定う激い治い義国間と持者れ方

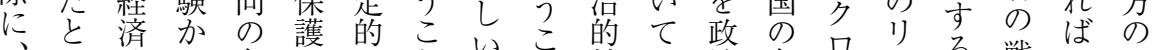

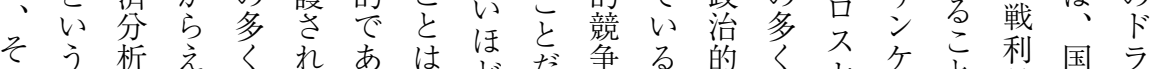

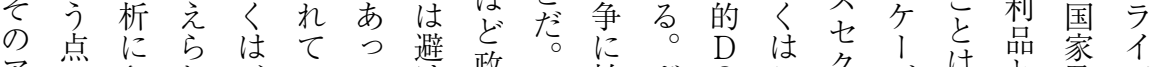

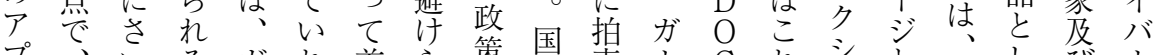

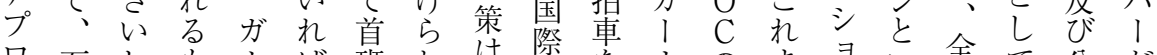

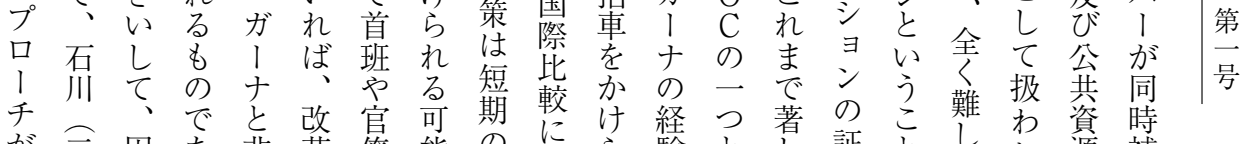

が二因 あ 非革 僚能の昭ら験とし証としれ源補

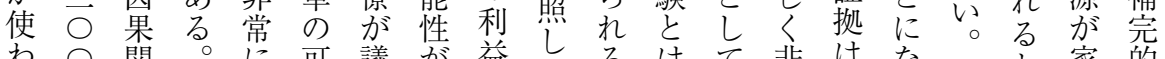

わ○関。に可議が益てるは非はな家的

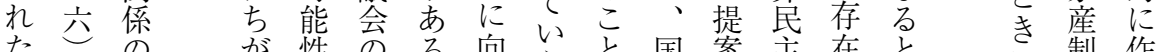

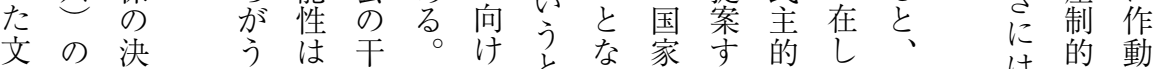

文の派ア 定 東大

主を射重「主

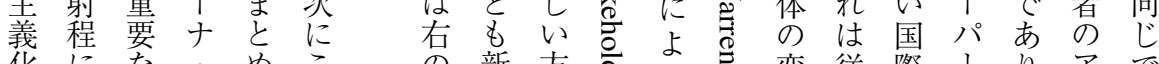

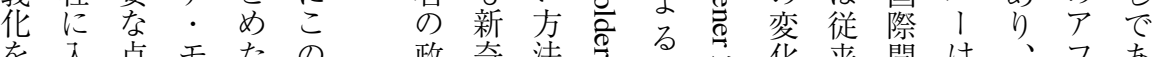

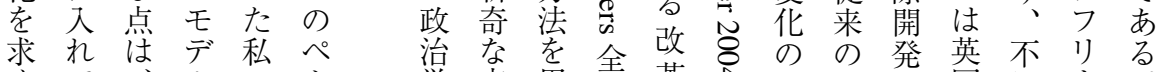
めて、学点用体革 $匚$ 中

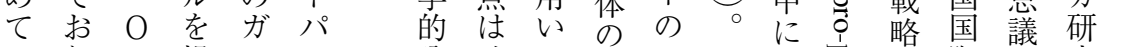
る 、 $\mathrm{D}$ 提 I I 分 政 る 動意 $\mathrm{D}$ 現 焉

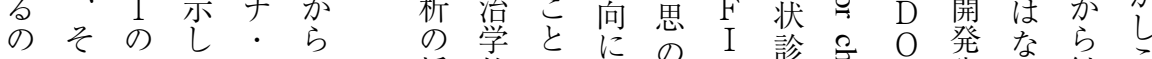
にの手デい モデ右 角分よ

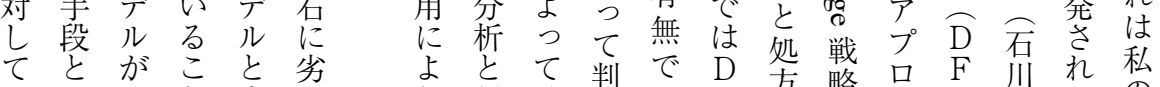

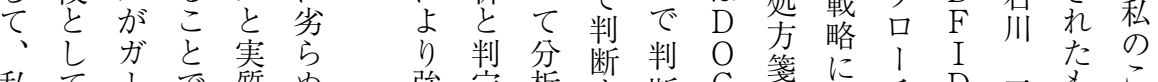

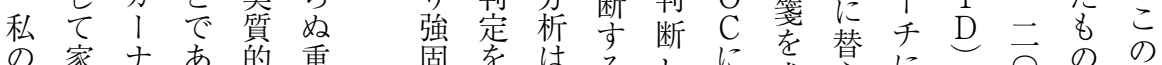

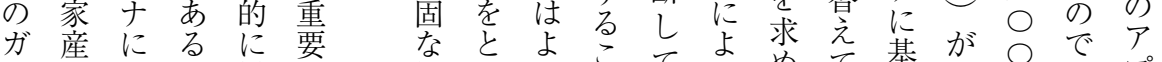
l 制お。異な 根り り と て る

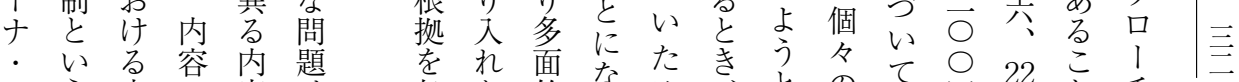

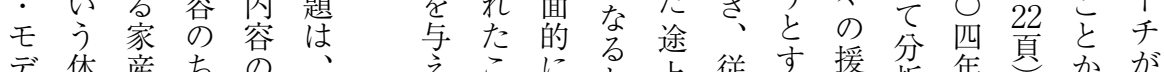

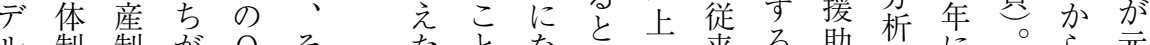

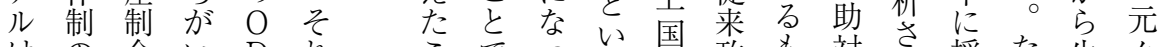

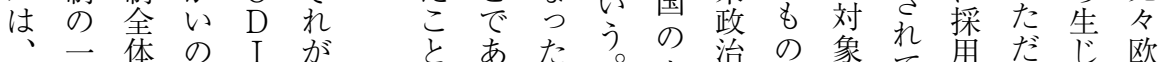
家挙のもに第にるが、実変的で国ていしした

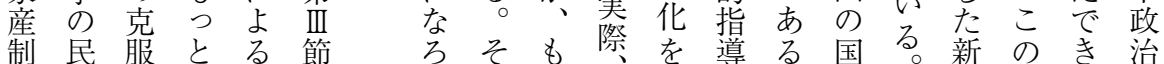




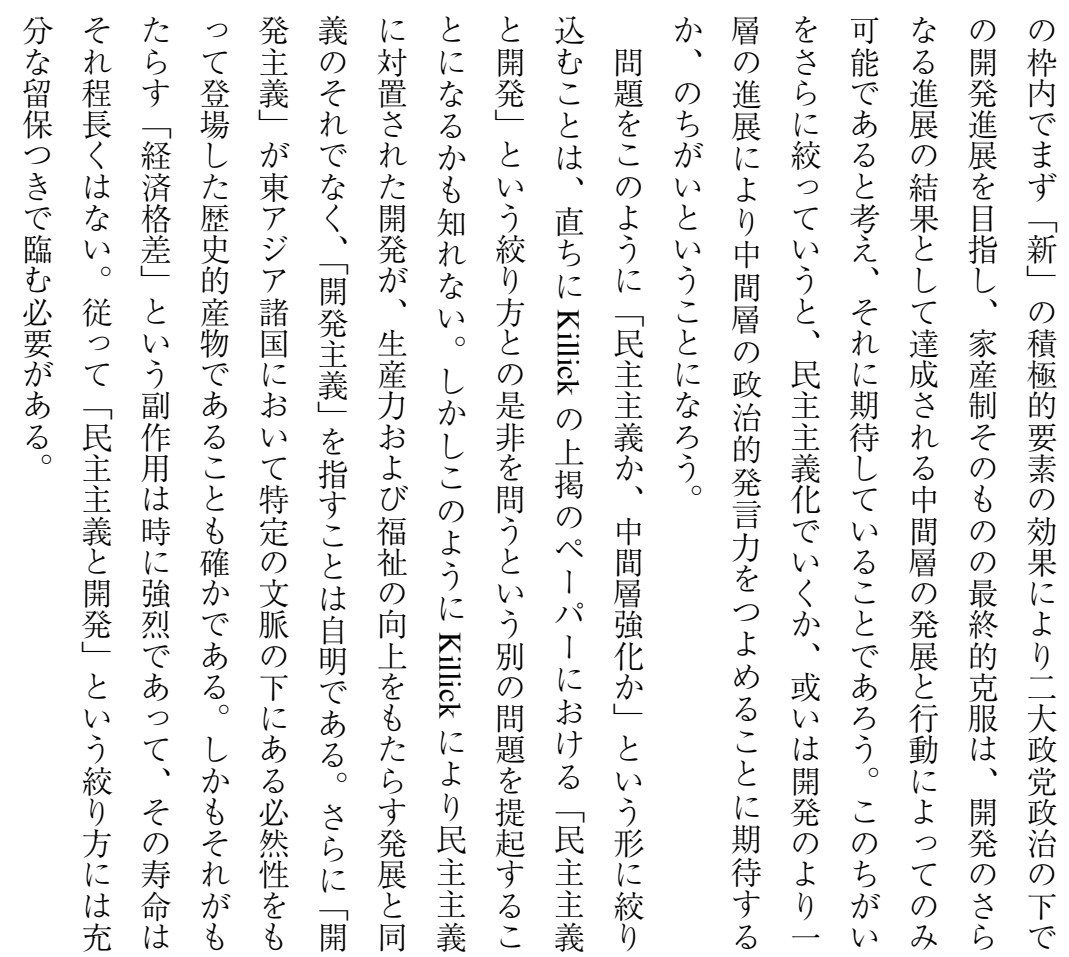

ク $\mathrm{N} \overparen{4}$ 成導い $\overparen{3}$ とをに一支る配民デ $\overparen{2}$ 身的な

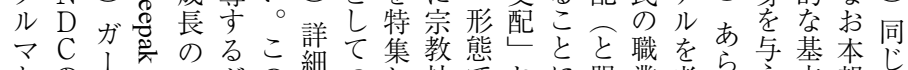

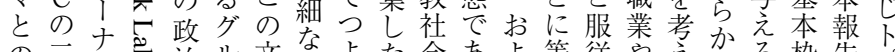
の二の心治ル文な経よた会あよ等従や㤂る枠告ピ

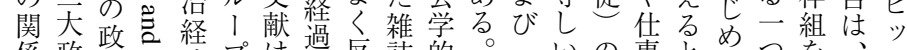

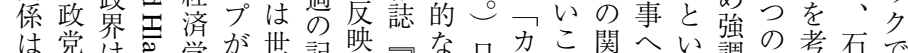
興の現る的実界訹し思官杲リと係のう調応察川で 味対在䓌研施銀とて想プにスでの倫こて用守こ私

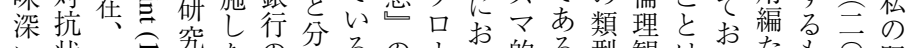
い状保㐫究たの分るの、け的る型観はきたも方既

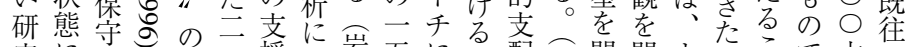
究に的・ガ二援つ岩五にウ配支問問ウいこで六の 課あなガカにい波名傾工配うう工のとあ研 題るブ +国よて書の斜、がの経宗、はをつが究 でがシナ比りは店社しバあ類済教バ、企た国と あ、アの較D宁、会て、り型社社、家図の際し

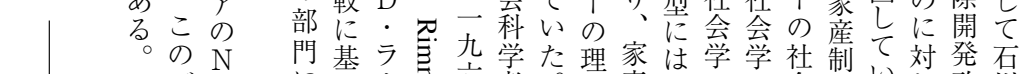

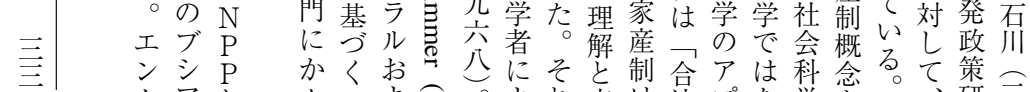

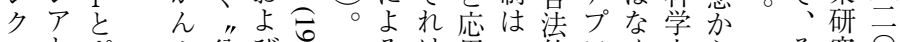
ルとポす貧びょるは用子的口く方ら マ初ピ方困 $\mathrm{H}$ 代 ユ

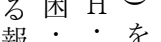
論現は伝支! 、法出 そ究 $\vec{\bigcirc}$ そ究 二大 告公ミ参 九 統 ス 五領卜 ○工的 文代、統配千人論発 集中従的治々とし に国来支々沿のして もの圧配伝つ間て開 あお卜隿 あるすれ辛た 実理倒統ての、発 に関五 実古 $\mathrm{a}$ 体劣が 的方古 な法あ 本鳥報 報正告 告喜の にの草 た五稿 い氏段 しか階 てらに も与招 貴えい 重占て なれも 批た艺 評有 が益 与な产 え批 ら評黒 れに崎 た感卓 謝 す水 学櫻
院坓
に 躬
お雄 


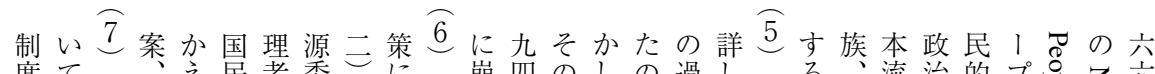

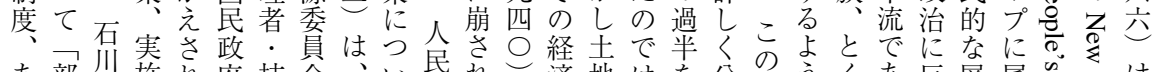
あ部川施れ府技会い共れ。済地はを分の閙く交層属的をは る門二に、が術会国て共た家効改な占析間ににる対をすもひ元

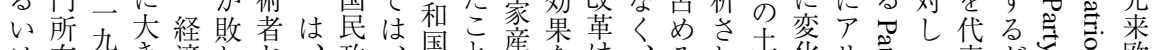

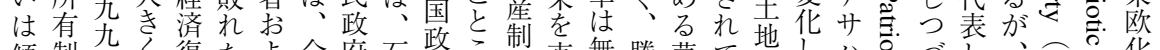

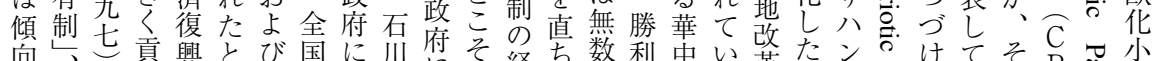

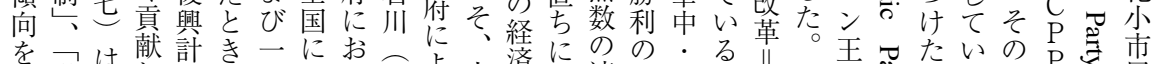

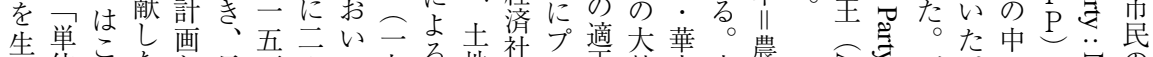

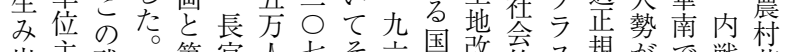
出主残 第官人七そ六良改的不瞡がで戦革 し義漳烈以ののの○政基と模決はの命

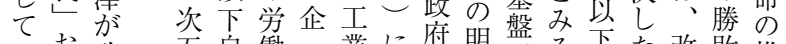
いお政五自㗢: 業に府明盐る下た改敗推

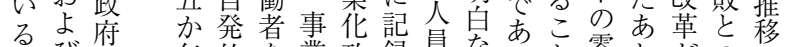
こび! 年的を業政録員なると零とがのは と国計に擁体策さ赫朝たは細で成関田

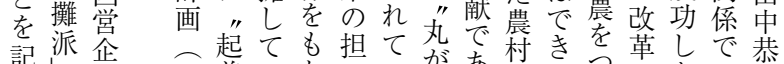
記㧘二義いち、いいがあ村なつ怔たい子 てと部九莪た二手るかっ地いく平たえこ いい門 五しが二で。えた章つ出穏めばニ

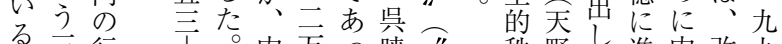
る三行言宁宁暁包秩野九進内改九

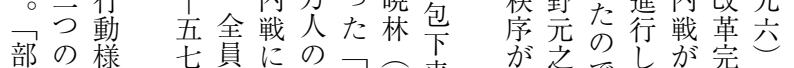
門 非式

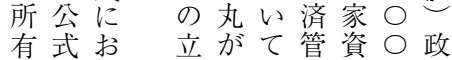
が経国三来 徹助あ゙た勝了に 底市。利地よ

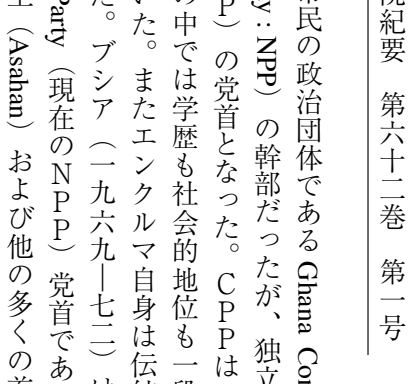
首つは統段 $\mathrm{N}$ 立号 長た欧的と $\mathrm{P}$ て 化

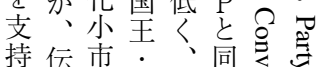
基統民首よじき 盤統層長り真現 と王の制庶ルき在

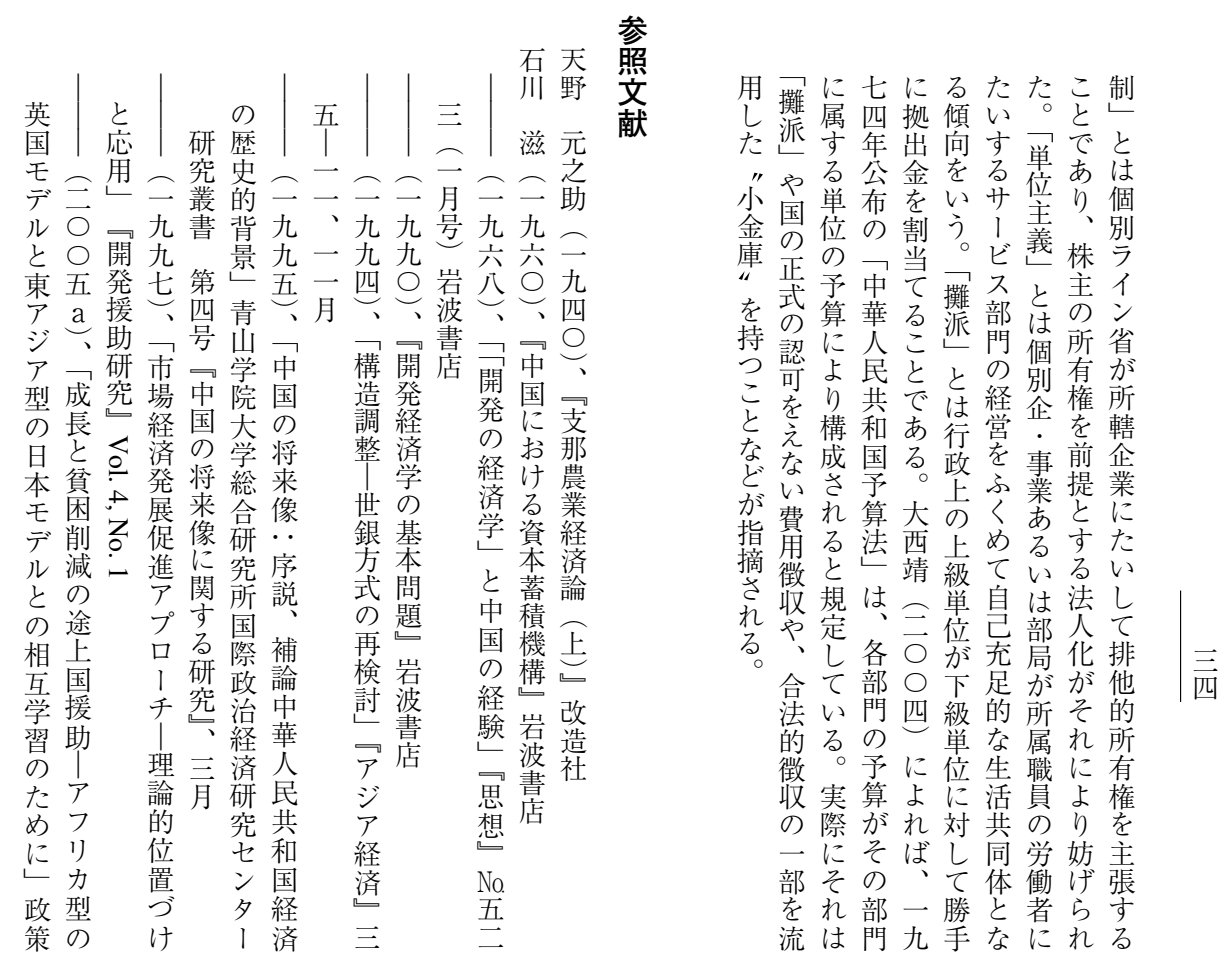




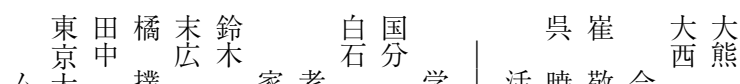

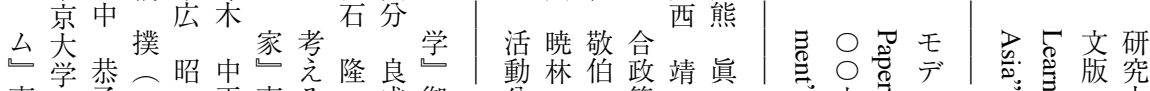

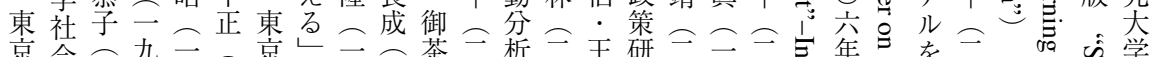

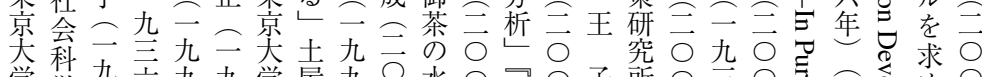

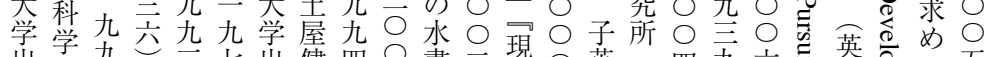

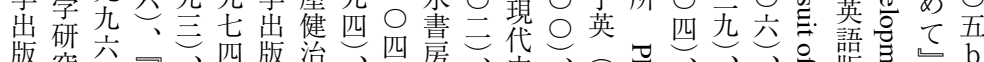

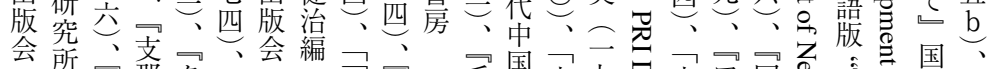
二圭社イ中田峝睍 二地会国講発帒 九権研開史 八力究発に 現国国 代家の 中杲导け 20 国本主 る 世農評主革

紀村論義命 贻岩岩宗 公名唐東 アの政 治政 治 治と 1 文官 ナ、制 シイル ナド応 リ戔 ズシ 熟

開 屋 発学 厶㚐学 と新学 シ出 出 国秩出
ス版会版 出版版包序版 毛
菓
時
氐
の
工業
化
戦
略
三
線
建
設
の
政
治
経
済

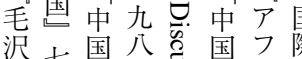
七国八气国フ際も气战貧

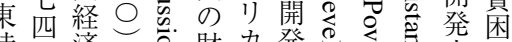
時号済、气財力発爷@气高の 代建

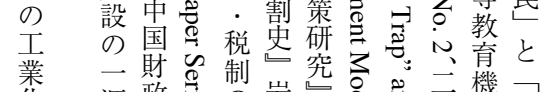

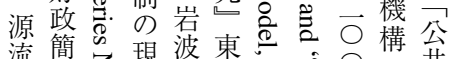

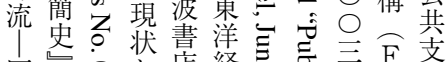

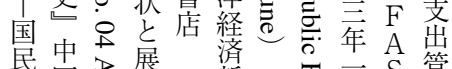
民国品望新可二S 管

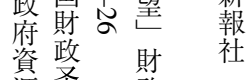
源 圣 委蛽省 テ会会

国を会

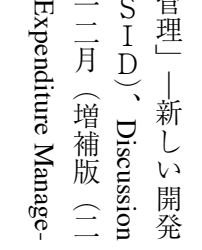

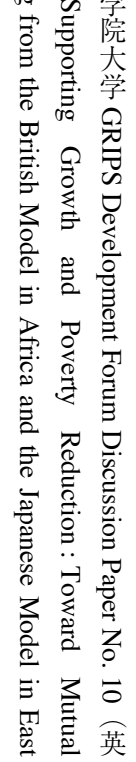

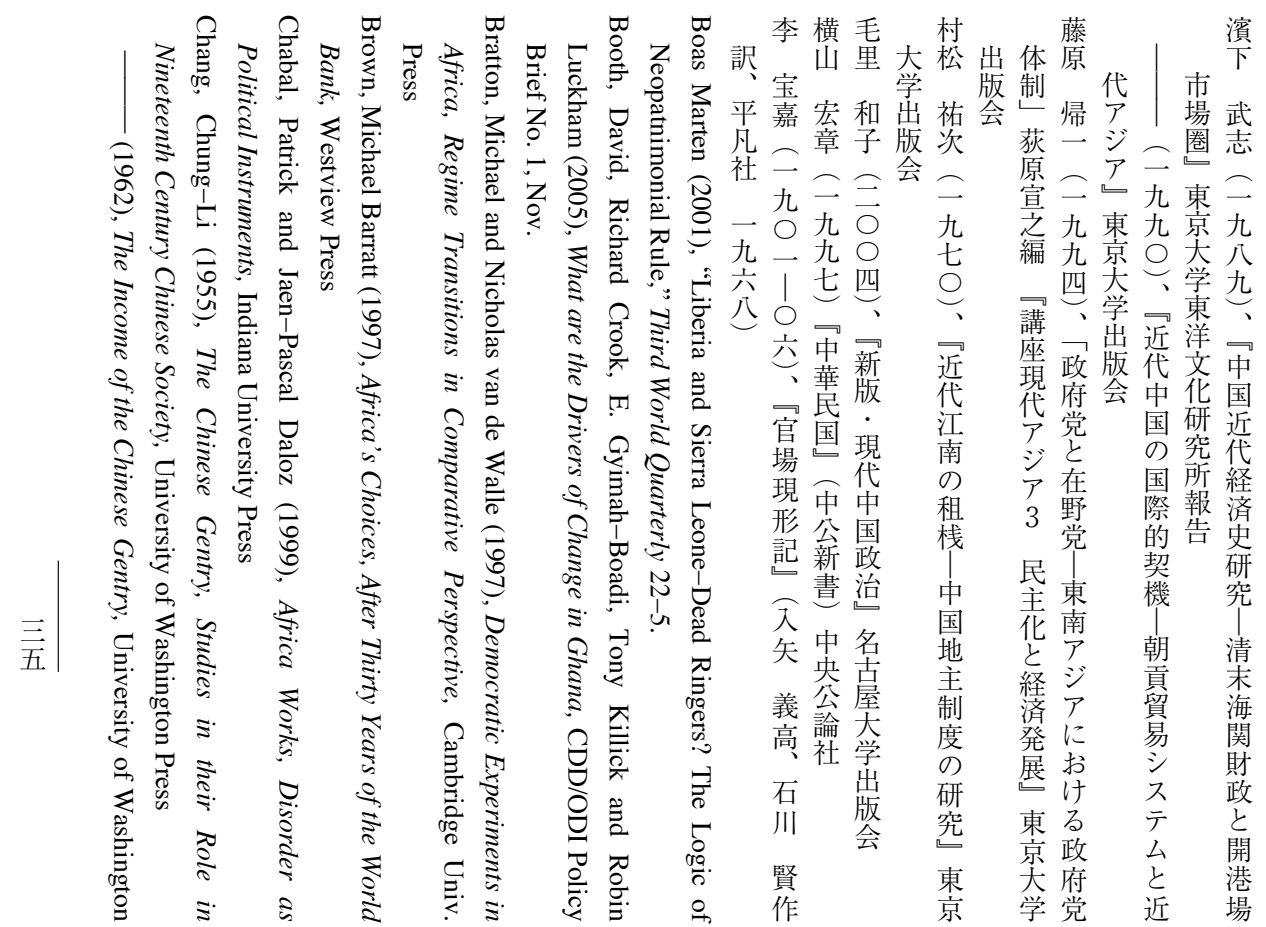




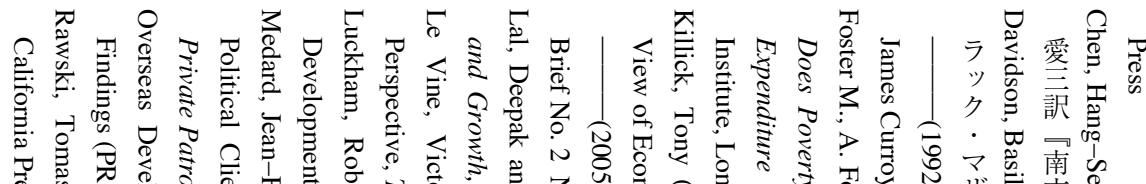

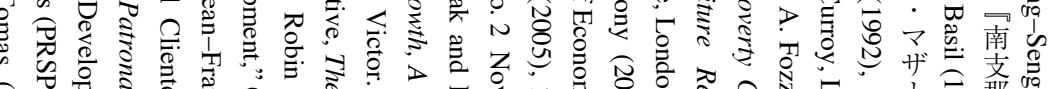

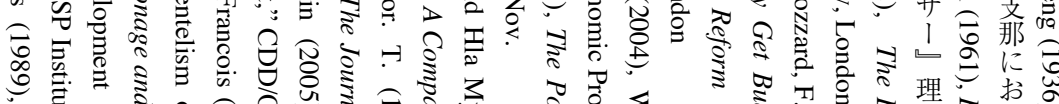

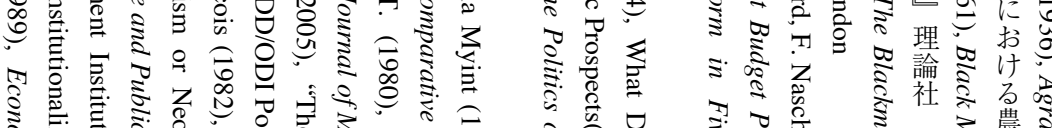

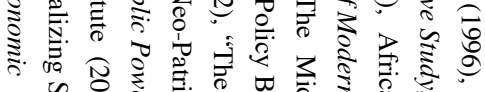

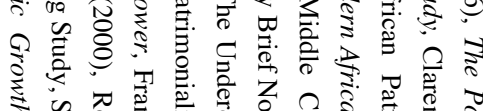

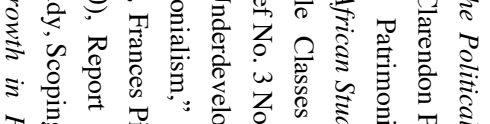

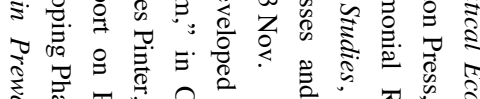

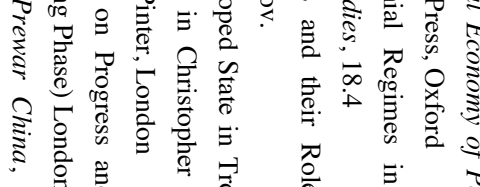

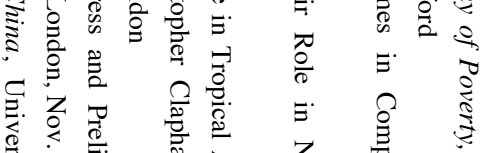

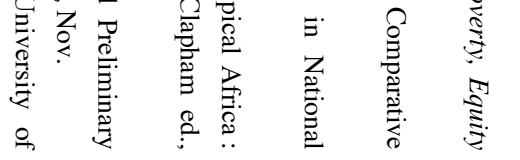

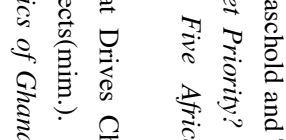

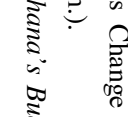
实诘言

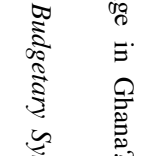

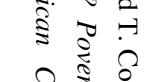

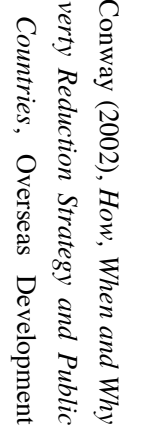

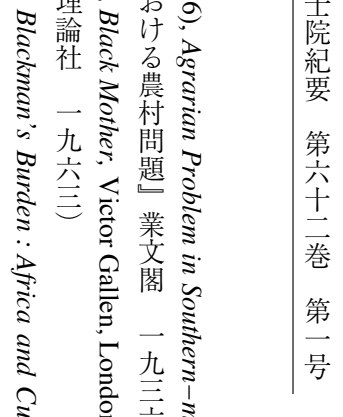

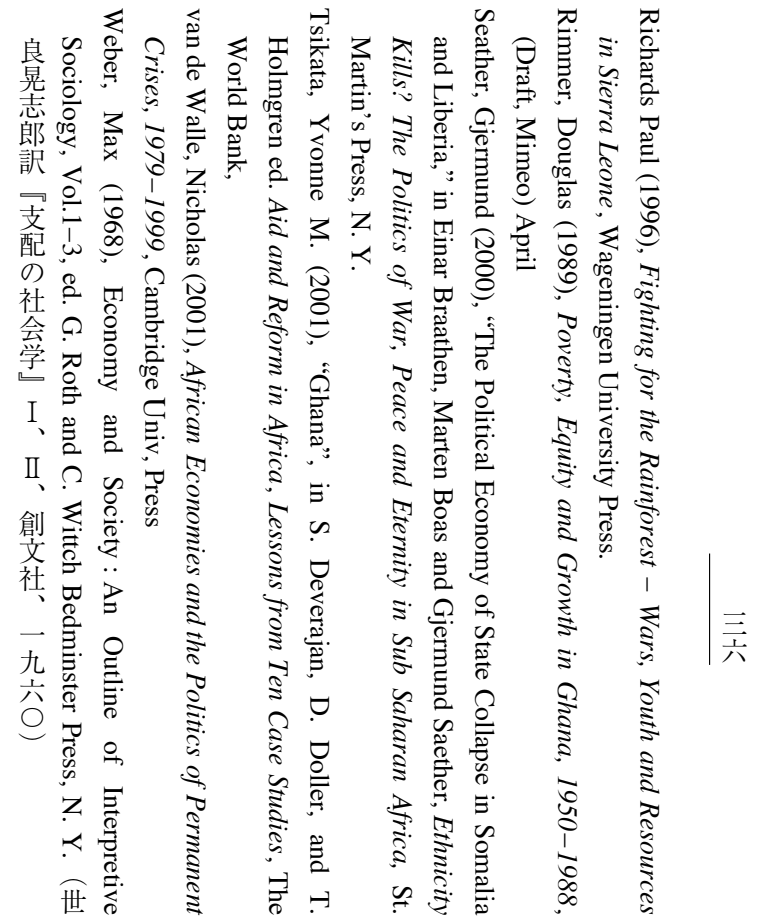




\section{附表 1 ガーナの開発モデル}

1. 体制と制度 (与件)

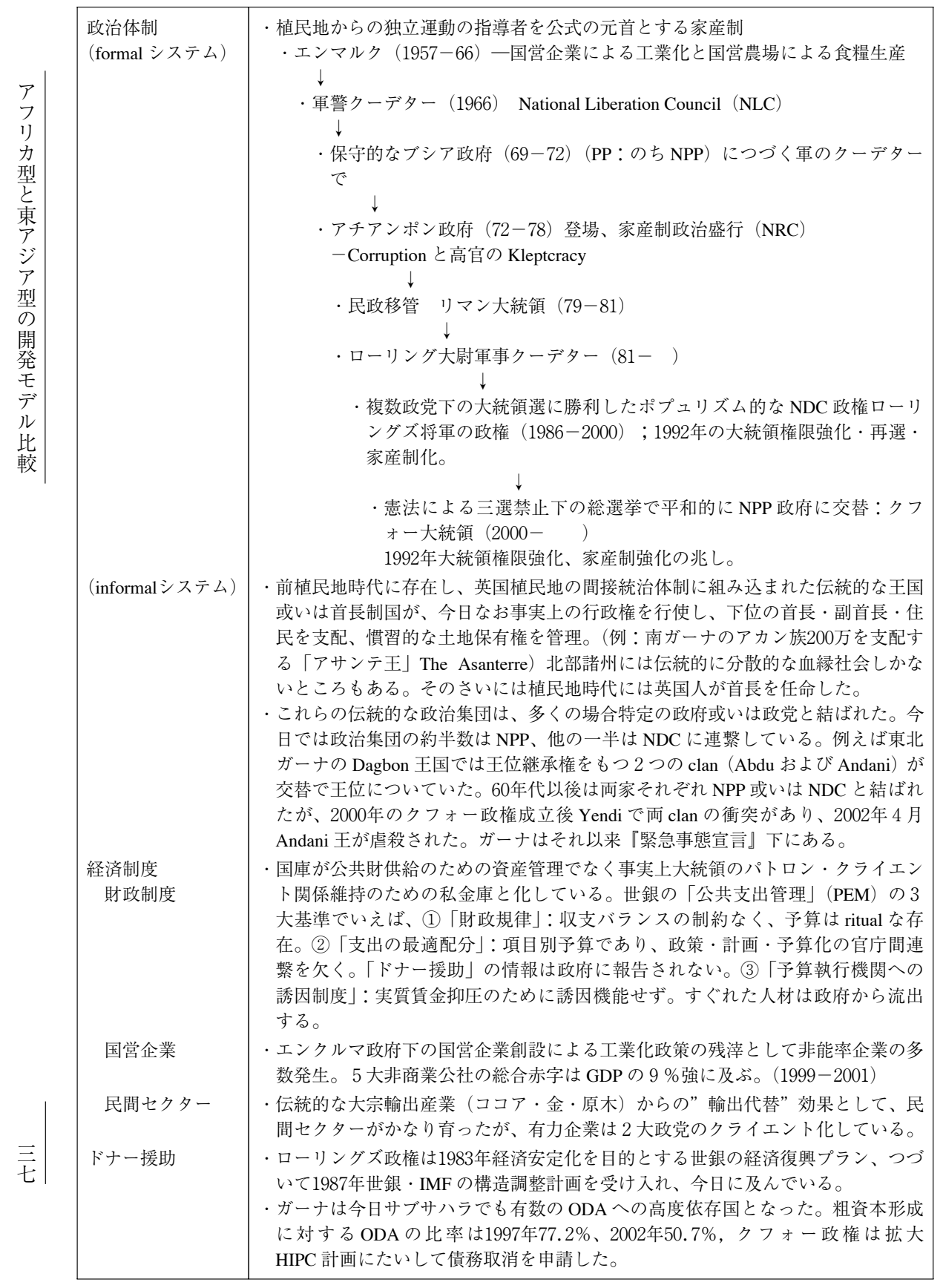


2. 制度組織の所与の発展段階の下での開発プロセス（諸「変数」間の相互作用）

\begin{tabular}{|c|c|}
\hline 成長実績 & 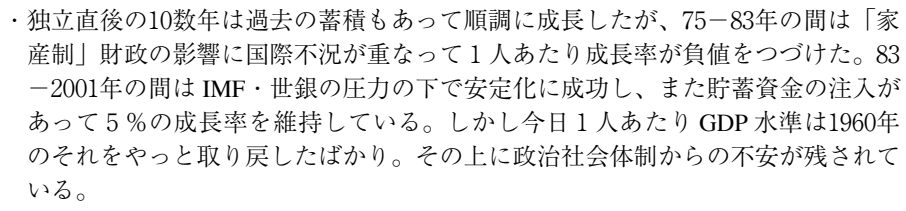 \\
\hline 財政 & $\begin{array}{l}\text { ·家産制体制は「内·外債の累積－利子払いの重圧－高率インフレ」の悪循環をも } \\
\text { たらした。それ断ち切るため、クフォー政権は拡大 HIPC の債務帳消し計画に } \\
\text { 参加申請した。内債債務については対 GNP の } 29 \% \text { (2000年末)を近く半減し、利 } \\
\text { 払の縮小、民間セクターへの信用の crowding-out の除去を狙っている。 }\end{array}$ \\
\hline 輸出·輸出産業 & 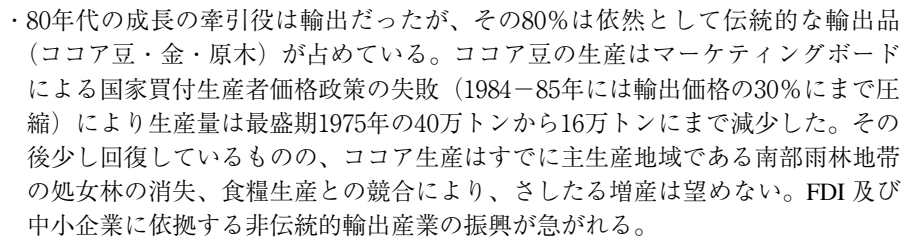 \\
\hline 貧困削減 & $\begin{array}{l}\text { ·国定貧困率は1992年の50\%から } 99 \text { 年39.5\%（国際基準では44.8\%）に漸減してい } \\
\text { る。しかし貧困率には著しい地域差があり、北部諸州のサバンナ地帯農村の貧困 } \\
\text { が重大。生計の “一般的危機”（全年或いは } 1 \text { 年の } 1 \text { 部基礎的食糧の著しい不足） } \\
\text { が支配的な形。“生き残り戦略” は出稼ぎに移った。しかし、それは地元コミュ } \\
\text { ニティの弱体化をもたらし、伝統的な相互扶助の道を失わせつつある。 }\end{array}$ \\
\hline
\end{tabular}

（注）本報告では開発モデルは制度の側面に絞って記述することを旨としているが、この附表は成長側面 との関係も考慮している。なお「与件」、变数」という用語が附してあるのは、この総合的モデル が石川（2006）における「基本枠組み」の「開発モデル」のパターンにそい、また後者が Walracian の一般均衡理論の分析枠組に基づくものであることを示している。 
economic growth can supply alternative means for promoting democratic reforms. Our investigation indicates that while Ghana's modernization appears to be in progress due mainly to the positive role of the "neo" aspects of neopatrimonialism in the 1980s and the 1990s, basic elements of patrimonialism, which are counter-productive to development, remain operative in the country.

5. A final exercise in mutual learning is facilitated by a comprehensive policy-oriented survey recently conducted by ODI of Ghana development (using a Drivers of Change analysis). Also, Tonny Killick, a senior member of this survey team, published a Ghana model that may be of his own construction but seems to represent well the thinking of survey team as a whole. This Ghana model's principal component is based on a concept that Ghana's advance to a democratic regime will be made possible principally by driving political factors, especially by intensifying party competition, while supplemented by other reforms in economic sector. Thus, a study to compare these two Ghana models, one based on the East Asian experience and the other purely on a British perspective, is likely to provide us with a new starting line for mutual learning. The central subject of this comparison is narrowed down to "democratization versus middle class expansion."

6. It is interesting to note that in the same paper, Killick contrasted his Ghana model with a hypothetical case where Ghana follows the deveolpmentalist policy of East Asian countries. He argues that although cross-country evidence indicates better development performance in the East Asian case, Ghana is not likely to take the developmentalist path because policy autonomy and effectiveness would not increase in Ghana without a spur of political competition. In Killick's mind, therefore, the central subject for comparison between the two Ghana models would be "democracy and development" (probably more strict worded “developmentalism”). For the task of mutual learning, we may wish to also compare these two sets of central subjects when comparing the two Ghana models. 
state and functions of patrimonialism (and related neopatrimonialism) are as follows: (1) There is a 2-phase process of patrimonialism formation in West Africa: one related to the success of independence movements by native leaders who originated from "recaptive" slaves in West Atlantic slave trade, and the other related to the newly independent native governments' attempts to compromise with local traditional kingdoms and chiefdoms in an effort to supplement the poor political and financial bases of their governments. (2) Some of the positive elements of the "neo" aspects of neopatrimonialism are playing a vital role in improving the administration of patrimonial governments; in particular the Structural Adjustment Lending (Facilities) of the World Bank and IMF with conditionalities for promoting marketization of their economies, and other sets of external aid with conditionalities for political liberalization and democratization. One such remarkable example is Ghana in the 1980s and 1990s. By the early 2000s, Ghana appeared to have become a most promising country in West Africa both politically and in terms of economic development, although patrimonialism is still operative.

4. From this investigation, we were able to isolate three country development (institution) models: a China model, a Thai model, and a Ghana model. In China, age-old patrimonialism was destroyed by the time the People's Republic of China was established due to the disintegration of its socio-economic foundation. However, factors that historically eventuated patrimonialism-e.g., the need to construct and maintain large-scale projects for flood control and irrigation-remain. Population pressure continues to be a salient factor, which requires maintaining a sufficiently high rate of GDP growth to sustain an acceptable rate of employment. Therefore, the PRC government can only be stable and secure if they are developmentalist. Our China model suggests that in China, development toward democracy is likely only when through further economic growth the middle class expands to the extent that is able to exert pressure upon the government to introduce democratic reforms. An example of progress in this direction is General Secretary Chiang Zemin's decision to admit private capitalists into the Communist Party at its 16th Party Congress (Nov. 2002). Our Thai model suggests a similar possibility.

We formed our Ghana model by drawing upon the experiences of China and Thailand; that is, in the countries where socio-political conditions have not yet matured enough to introduce a democratic regime, middle class expansion as the basis of 


\title{
Comparison of African Type Development Model with East-Asian Type
}

\author{
Shigeru ISHIKAWA, M. J. A.
}

1. In my recent book (Ishikawa 2006), I tried to devise a basic framework for analyzing international development policy with serious concern placed on the development potentiality of Sub-Saharan African countries as the countries most probably at the last development frontier in this century. This basic framework has two features.

(1) International development is analyzed as consisting of two parts: (1) a "development model" of a particular aid-receiving developing country that is designed by neutral researchers (an objective model), and (2) an "external aid system" of an individual donor, which consists of the donor's own development model as applied to the recipient (that is, a subjective model partly drawn from an objective model), and the forms and amounts of aid to the recipient.

(2) Probably for the first time in economic development studies, within this framework a political factor is consciously utilized as an instrumental development determinant. Moreover, a Weberian-type concept of patrimonialism and related new concept, neopatrimonialism are identified as a presently operative political factor in Africa and an already-overcome political factor in some East Asian countries.

2. The present paper applies this basic framework to an issue that I have been most interested in over recent years, namely comparing development models in countries of East Asia, about which the Japanese have been most concerned, with those of SubSaharan Africia, which appear to have recently become the main focus of British international development policy. The ultimate aim of this comparison is to enable those engaged in international development policy in the two countries to benefit from mutual learning.

3. A major investigation was conducted on comparing both past and possibly-forthcoming paths from patrimonialism to democratic regimes in each region. For this investigation, particular subregions and/or countries were selected: West Africa and frequently Ghana for Africa; and China and Thailand for East Asia. Among our findings on the current 